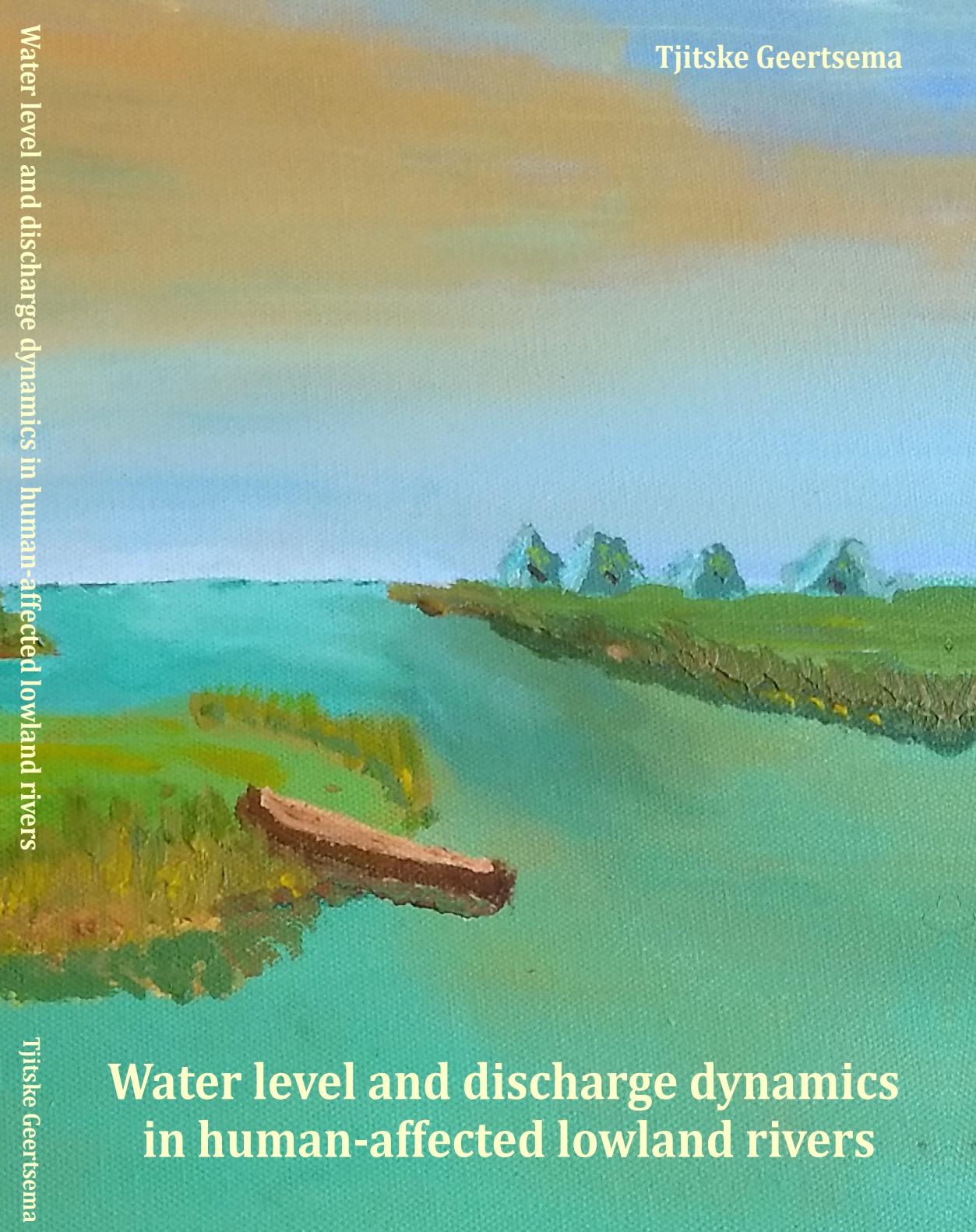




\section{Water level and discharge dynamics in human-affected lowland rivers}




\section{Thesis committee}

\section{Promotors}

Prof. Dr A.J.F. Hoitink

Personal Chair, Hydrology and Quantitative Water Management Group

Wageningen University \& Research

Prof. Dr R. Uijlenhoet

Professor of Hydrology and Quantitative Water Management

Wageningen University \& Research

\section{Co-promotor}

Dr A.J. Teuling

Associate professor, Hydrology and Quantitative Water Management Group Wageningen University \& Research

\section{Other members}

Prof. Dr F. Ludwig, Wageningen University \& Research

Prof. Dr M.G. Kleinhans, Utrecht University

Prof. Dr E. Wohl, Colorado State University, USA

Prof. Dr P. Willems, KU Leuven, Belgium

This research was conducted under the auspices of the Graduate School for Socio-Economic and Natural Sciences of the Environment (SENSE) 


\section{Water level and discharge dynamics in human-affected lowland rivers}

Tjitske J. Geertsema

Thesis

submitted in fulfillment of the requirements for the degree of doctor at Wageningen University by the authority of the Rector Magnificus

Prof. Dr A.P. J. Mol, in the presence of the

Thesis Committee appointed by the Academic Board to be defended in public on Friday 20 December 2019 at 11 a.m. in the Aula. 
Tjitske J. Geertsema

Water level and discharge dynamics in human-affected lowland rivers, viii+138 pages.

$\mathrm{PhD}$ thesis, Wageningen University, Wageningen, the Netherlands (2019) With references, with summaries in Dutch and English

ISBN 978-94-6395-104-3

DOI $10.18174 / 499084$ 
Albert Einstein wrote, "Everybody is a genius. But if you judge a fish by its ability to climb a tree, it will live its whole life believing that it is stupid."

Matthew Kelly, 2004 



\section{Contents}

Contents viii

Introduction 1

Wood-induced backwater effects in lowland streams 13

Flow patterns and backwater effects in sharp river bends 35

Regional groundwater response to accidental river lowering 55

Simultaneous flood peaks at a lowland confluence 73

Synthesis 103

Summary 117

Samenvatting 123

Dankwoord 129 


Chapter

1

\section{Introduction}

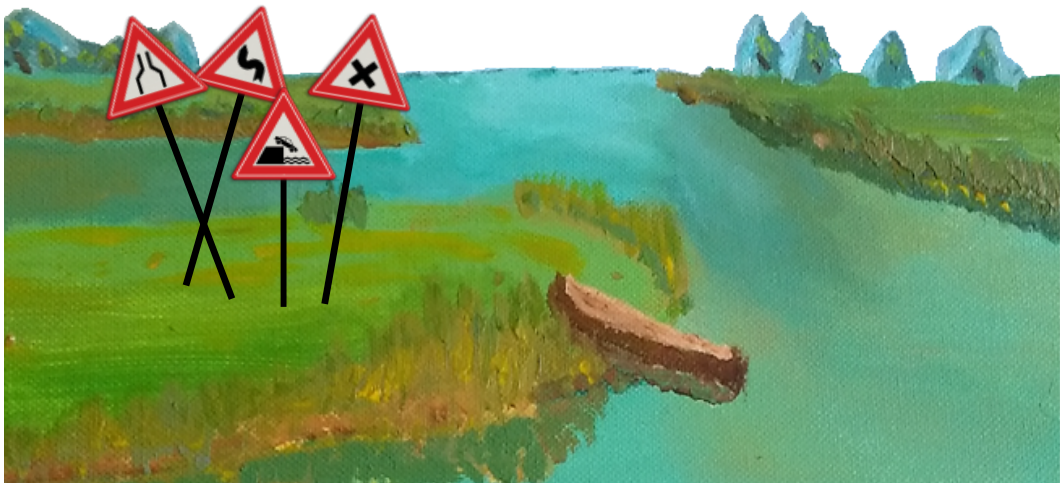


This thesis starts with the extraordinary story of the Netherlands, a lowland area where the Rhine and Meuse rivers flow into the sea. Almost half of this Rhine-Meuse lowland is located below Mean Sea Level (MSL) (Figure 1.1c). Nevertheless, it is home to about 17 million people. At the start of human occupation about 250 thousand years ago, living in this lowland area was problematic, because regular inundations threatened people and their food supplies (?). By trial and error, people slowly inhabited the delta and started creating small settlements. During the transgression period, in between the fifth and first centuries BC, sea level slowly rose combined with more frequent storms (???). This resulted in inland migration of the sea, further enhanced by human drainage activities for salt extraction (?). In response, people started constructing small hills to live on, or migrated to higher areas. From 800 AD onward, people started draining the lower areas by increasing the width of the (small) rivers, by digging ditches, and by extracting the peat (Figure 1.1a ??). Extensive peat extractions took place from the $10^{\text {th }}$ to $13^{\text {th }}$ centuries, and caused much of the land surface levels to drop below MSL. This is still is the case nowadays (Figure 1.1c ??). From that period onward, this non-natural humanaffected system needed extensive maintenance to prevent inundations from sea, rivers, precipitation and groundwater. Constant drainage is required and has resulted in the famous polder system. Groundwater levels are still nearly everywhere and all the time shallower than $1 \mathrm{~m}$ below the surface (Figure 1.1d). Lowlands are defined here as areas where hydrological processes are influenced by shallow groundwater and upstream areas are defined as freely draining areas within lowlands. In addition, the rivers are kept in place by dikes, groynes and are deepened by dredging. The sea is kept out by construction projects, such as the Delta Works and the enclosure dam called the Afsluitdijk (?), and by dunes, which need regular sand suppletion to maintain their strength (??). This non-natural humanaffected system is currently inhabited by more than 400 inhabitants per square kilometer (Figure 1.1b) and is producing a GNI of over 46,000 euro (51,000 dollars) per capita (the World Bank Databank; https://data.worldbank.org/country/net last access: 5 September 2019), predominantly in the lowest laying areas.

Similar to the Rhine-Meuse lowlands, lowland areas around the world are often densely populated and used for living, economic activities, and recreation (?????). The absence of relief makes these lowland areas extra vulnerable to flooding, and therefore these areas demand extensive and up-to-date maintenance or acceptance of losses. Water managers have to 

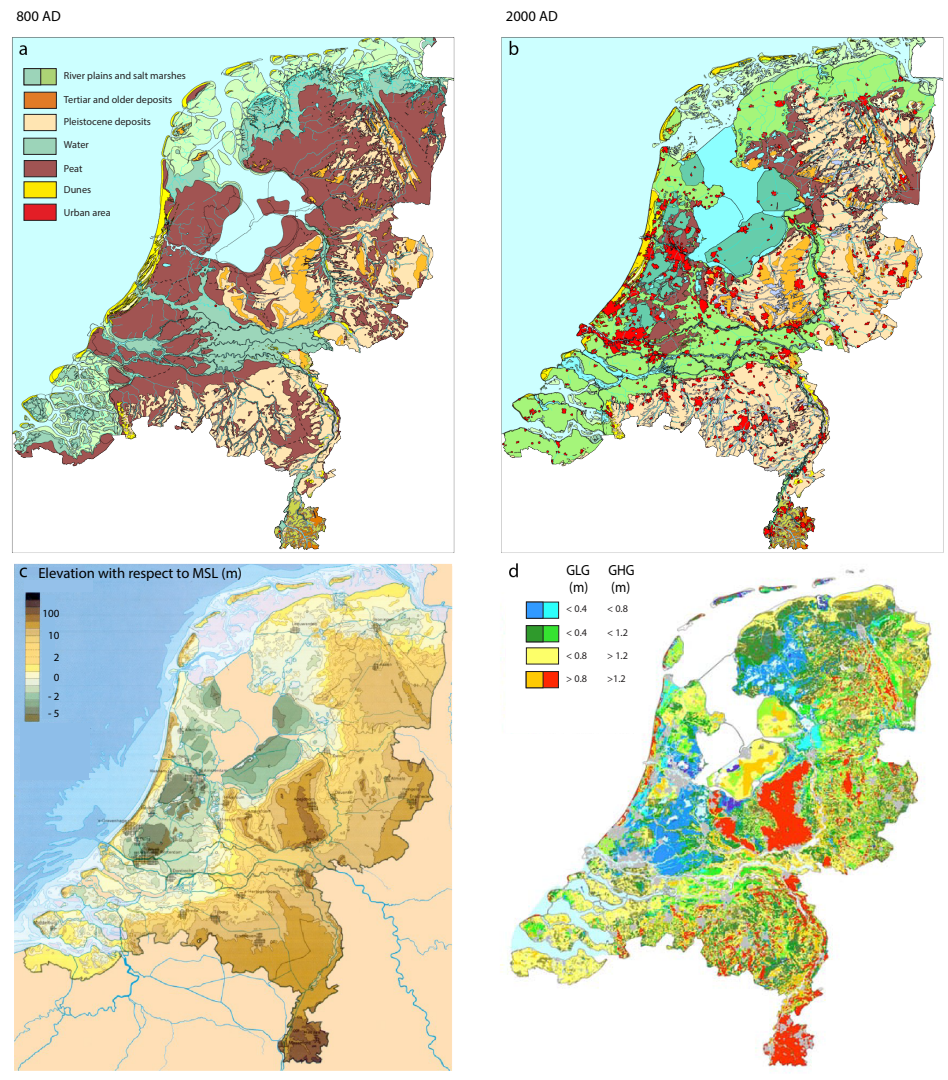

FIgURE 1.1. Physical-geographical overview of the Netherlands. Panel a and $b$ show the paleo-geographical maps from 800 A.D. and 2000 A.D., respectively (?). Panel c illustrates the elevation with respect to MSL (?) and panel d depicts the average yearly lowest (GLG) and highest (GHG) distance between groundwater table and surface (?).

ensure that flooding does not occur in these economically important yet vulnerable areas. Previously, this resulted in water management policies that were focused on fast drainage. Initially, this strategy was a success for making lowland areas suitable for, for instance, agricultural activities and large-scale constructions. In recent years, however, it has been acknowledged that this strategy negatively impacts aquatic ecology, water quality, groundwater levels in the vicinity of rivers and potential to floods 
or droughts. The water quality and biodiversity in freshwater has declined globally (e.g. ????????) as result of increased water temperatures, eutrophication and loss of habitat (e.g. ?????). Groundwater levels in the vicinity of rivers have dropped dramatically (???) creating an increased need for irrigation of crops and causing the subsidence of soils. The fast drainage strategy, moreover, has led to higher discharges in the major rivers resulting in more frequent floods in wet periods (???), but also prolonged droughts in upstream areas in dry periods. Climate effects will worsen these impacts by increasing precipitation intensities, droughts duration and sea levels (????). This was already apparent from various weather extremes resulting in droughts and floods during the research project that led to this thesis. The years 2014 to 2018 were globally the five warmest years ever measured (since 1880) (?), of which 2018 exhibited the highest European average temperature anomaly on record of +1.78 degrees, (?) and resulted in an estimated economic loss of 0.45 to 2 billion euros only in the Netherlands (?). In 2016 the highest June precipitation ever measured fell in Brabant and Limburg, the Netherlands (?), which resulted in an estimated damage of more than 500 million euros for predominantly local farmers (?, in Dutch). Lowland areas around the world will demand more extensive management due to the increasing likelihood of extreme precipitation and rising sea levels. Moreover, the mentioned problems will occur more frequently, inducing large costs and losses of environment.

In order to tackle these problems, precise water management is required. This water management style is predominantly applied in agricultural studies and on small scales (??). However, the above problems require precise water management on large scales, which entails flexible management both in space and time, without changing the functioning of the system. Examples are storm water management, channel reconfiguration, dam adaptations and flood plain restoration (?). According to ?, these measures are less expensive on the long term than short-term floodrelated costs. Water retention is seen as the new policy measure to apply precise water management as much as possible by retaining water in the upstream regions of lowlands. With the help of water retention, water can be used in dry periods and does not contribute to the high water levels in the large rivers during the wet periods. Lowland areas are better suited for water retention than mountainous basins, due to their deeper soils and gentle slopes. Moreover, water retention counteracts the fast drainage strategy and increases the connectivity of the river system without chang- 
ing the current function (?). River connectivity is currently seen as the best option for environmental improvements in rivers, because it connects environments in space and time (???). Four ways to (temporarily) store additional water in the system can be identified:

- increase storage capacity of soils,

- create storage facilities outside the natural system,

- increase surface water levels,

- delay discharge.

Increasing the storage capacity of soils is currently not seen as a viable measure at larger scales (???), since the small retention gain will not outweigh the costs. It is not advisable to consider creating storage facilities outside the natural system either, because this is not a natural solution and will therefore not counteract the environmental losses or contribute to the river connectivity. Increasing water levels and delaying discharges are identified as key mechanisms for retaining water naturally, especially because the water level and discharge impacts of the fast drainage strategy are currently causing problems. This thesis therefore focuses on the water level and discharge dynamics in the human-affected Rhine-Meuse lowland.

Current stream and river restoration measures are already resulting in water level increase and discharge delay. Water level increase is achieved by inserting wood in streams (?), and discharge delay is achieved by remeandering the river. However, the local controls of these two measures for water retention purpose have not yet been scientifically studied. Moreover, increased water levels and delayed discharges impact the regional water system via river-groundwater interaction and via catchment functioning, both of which are not yet fully understood. This thesis will study the wood-induced backwater effects in lowland streams (Chapter 2), the flow patterns and backwater effects in sharp lowland bends (Chapter 3), the regional groundwater response to instantaneous lowering of river water levels (Chapter 4) and the simultaneous occurrence of flood peaks at a lowland confluence (Chapter 5). These studies are organized according to their contribution to increase water levels or delay discharges and by their impacts on local or regional scale (Figure 1.2). The main objective of this thesis is to understand the local controls on and regional impacts of 
the water level and discharge dynamics in human-affected lowland rivers. Below, the contribution and impacts per study are explained.

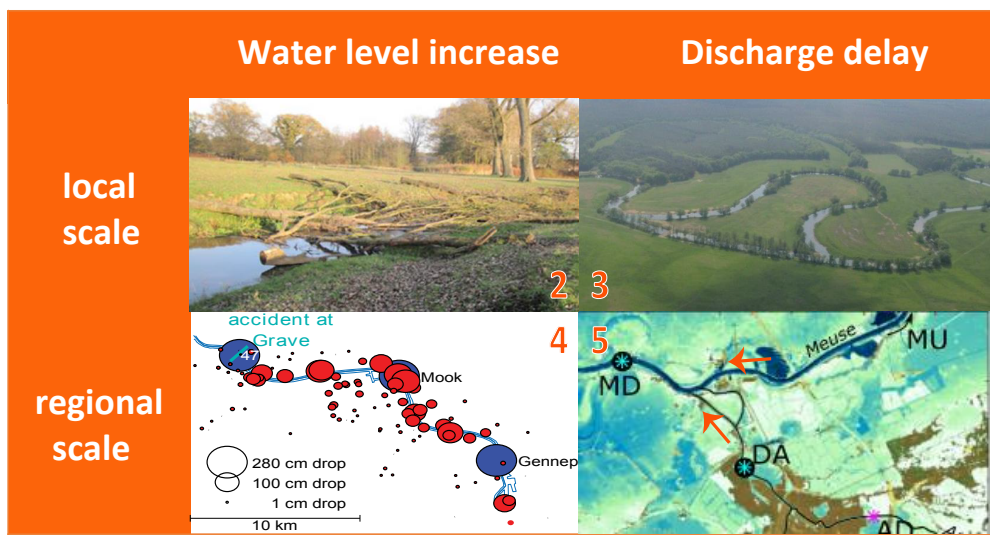

FIGURE 1.2. Framework of the connection between chapters. The numbers represent the corresponding chapter numbers. The chapters in this thesis vary in their focus on scale, local or regional, and variable, water level or discharge as indicated in the figure.

\section{Chapter 2: Wood-induced backwater effects in lowland streams}

Insertion of wood in streams is a common method to increase ecological value in river restoration projects (??) and is therefore widely used in streams in nature areas. Water managers, however, are often afraid to introduce wood in agricultural and urban areas since wood in streams has an effect on flow deformation (????) and flow resistance (????). These processes provide morphological activity, both laterally through bank erosion and protection, and vertically with pool and riffle formation (???????). These processes, moreover, can create backwater effects upstream of the inserted wood, which potentially induce flooding (?????). In the current literature (??????), flow deformation and resistance are referred to as the most important consequences of wood in streams. However, theory, laboratory experiments and pilot studies for bridges and spur dikes show that obstruction ratio, Froude number and gradient also characterize the height of the backwater effect (?????????). The dynamics of obstruction ratio and discharge could thus be more relevant than previously assumed. The pur- 
pose of this study is to quantify the dynamics of wood-induced backwater effect in lowland streams. The following research questions are addressed:

- What are the observed backwater effects under various flow conditions?

- Can the observed effects be predicted from a conceptual model?

- How sensitive are the predicted backwater effects to the geometry of wood configurations? 
Chapter 3: Flow patterns and backwater effects in sharp lowland river bends

Delaying discharge can be created by a longer thalweg to increase advection and diffusion. This is achieved in (re)-meandering projects. In August 2010, a flood occurred at a recently constructed Dutch remeandering project during a high discharge peak, which was not predicted and could not be reconstructed by the model used by the water board (personal communication with water manager Ellen Bollen-Weide). In addition, models for some meandering projects gave their best results with unrealistic Chézy parameters during calibration (personal communication with water manager Michelle Berg). This shows that bend processes are still hard to capture in models and it is therefore necessary to increase the knowledge of river bend processes, to prevent flooding and to improve forecasts (???). Bends have a characteristic flow pattern that results in a water level increase (??), which could be caused by a delay in discharge. According to ?, the water level increase is caused by turbulence, complex flow patterns and bed topography (????????). However, the (temporal) stability of these complex flow patterns and thus the additional water level increase in relation to discharge conditions has not yet been studied. The purpose of chapter 3 is, therefore, to understand the effect of discharge conditions on the stability of complex flow patterns and backwater effects. The following research questions are addressed:

- How does the appearance of horizontal flow recirculation cells depend on discharge?

- Which mechanisms explain the observed changes?

\section{Chapter 4: Regional groundwater response to instantaneous lowering of river water levels}

Groundwater availability is largely influenced by (long-term) rainfall patterns, geology and drainage to surface water. The exchange between groundwater and surface water, however, changes in time because of changes in surface water level (e.g. ?????). When surface water levels are regulated, the change in surface water can be managed to increase water availability and to serve as climate adaptation strategy. The groundwater and surface water levels could, for instance, be lowered before a large rain event is expected, using nowcasting (????). Nowcasting enables short-term weather 
forecasts, which allows to change groundwater levels to anticipate on predicted precipitation. It is, however, unknown whether the groundwater response is fast enough in relation to accurate short-term forecasts. When the groundwater response is fast enough, groundwater and surface water levels can be preserved at higher levels during dry periods, because the water levels can be adapted within the period of accurate nowcasting. Before this sustainable water management strategy can be applied, regional groundwater and surface water exchange need to be better understood and predicted. Chapter 4 focuses on understanding the effective regional hydraulic conductivity and specific yield to predict regional groundwater response to an extreme lowering of river water levels in the Meuse River. The following research questions are addressed:

- What is the characteristic response time of groundwater to instantaneous lowering of river water levels, as function of distance from the stream?

- How does the hydraulic conductivity and specific yield obtained from local pumping tests and estimated using a regional lowering of river water levels differ?

\section{Chapter 5: Simultaneous occurrence of flood peaks at a lowland conflu- ence}

Delaying discharge might provide a local solution for water retention, but could lead to discharge peaks that regionally coincide with major consequences for flooding (???). The purpose of this study is to understand the mechanisms behind simultaneous occurrence of flood peaks. It is known that floods naturally coincide in the Walloon Ardennes of the Meuse (?). It is, however, unknown if discharge peaks also coincide in the lowland areas. Chapter 5 deals with the precipitation distribution and the time from precipitation to flood peak at the confluence based on the catchment characteristics (??). Also, the water level effects of simultaneous occurrence of flood peaks on the tributaries are studied. The following research questions are addressed:

- Under which circumstances do discharge peaks coincide at a lowland confluence?

- How does the coincidence of discharge peaks affect water levels? 
In Chapter 6, the formulated research questions are answered and the water level and discharge dynamics in relation to each other and in relation to other studies are discussed. Eventually, recommendations for future research and for water management are given. 


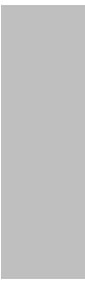


CHAPTER

\section{2 \\ Wood-induced backwater effects in lowland streams}

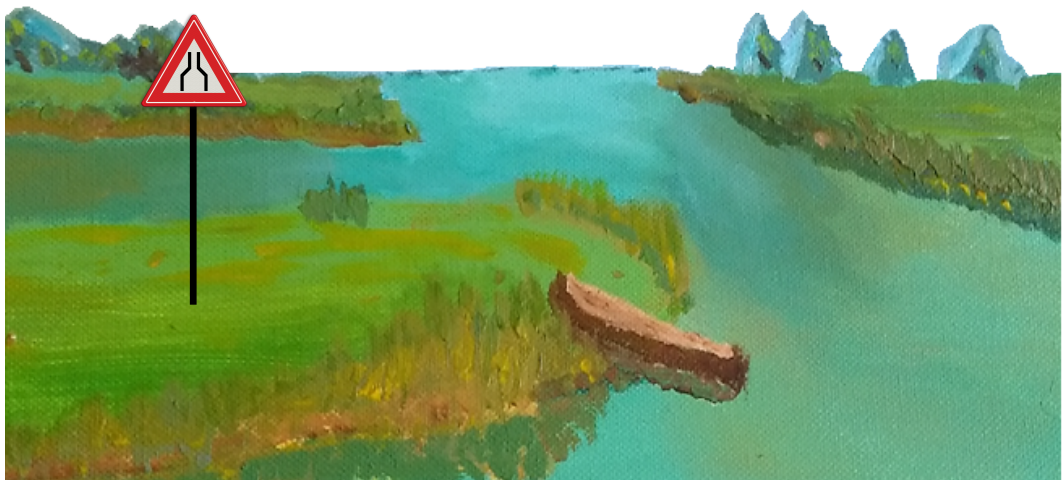

This chapter is based on: Geertsema, T. J., P. J. J. F. Torfs, A. J. Teuling A. J. F. HoITINK, Wood-induced backwater effects in lowland streams, River Research and Applications, accepted. 


\begin{abstract}
Placement of wood in streams has become a common method to increase ecological value in river and stream restoration and is widely used in natural environments. Water managers, however, are often hesitant to introduce wood in channels that drain agricultural and urban areas because of backwater effect concerns. This study aims to better understand the dependence of wood-induced backwater effects on cross sectional area reduction and on discharge variation. A newly developed, one-dimensional stationary model demonstrates how the water level drop over the wood patch significantly increases directly after wood insertion. The water level drop is found to increase with discharge, up to a maximum level. If the discharge increases beyond this maximum, the water level drop reduces to a value that may represent the situation without wood. This reduction predominately depends on the obstruction ratio, calculated as the area covered by wood in the channel cross-section divided by the total cross-section area. The model was calibrated with data from a field study in four lowland streams in the Netherlands. The field study showed that morphologic adjustments in the stream and reorientation of the woody material reduced the water level drop over the patches in time. The backwater effects can thus be reduced by optimizing the location where wood patches are placed, and by manipulating the obstruction ratio. The model can function as a generic tool to achieve a stream design with wood that optimizes the hydrological and ecological potential of streams.
\end{abstract}

\title{
2.1 Introduction
}

In the last three decades, the attitude towards wood in streams and its effects has changed considerably. Throughout the $20^{\text {th }}$ century, wood was systematically removed to increase flood conveyance as well as to improve navigability, to promote fish migration and to prevent erosion (????). In recent years, however, wood has been recognized as an integral part of the aquatic ecosystem and an important morphological trigger (?????). Moreover, conserving wood in streams can even be economically beneficial (??). In this light, EU water managers are encouraged to (re)introduce wood in streams following the Water Framework Directive (WFD) and US water managers are spending billions of US dollars on stream rehabilitation measures, many of which entail wood reintroduction (?). Despite the current implementations, the flood conveyance effects of wood in streams are 
still poorly understood. Therefore, water resource managers are often hesitant to (re)introduce wood in streams, particularly in lowland areas and areas with significant economic value.

In recent years, numerous studies have investigated the hydraulic effects of wood in streams. These studies have mainly concentrated on the effects of flow deformation and friction (???????) and on the development of wood jams (??????). Two studies have directly examined the water level increase of wood by setting up flume experiments based on a single cylindrical wood piece (?) and multiple wood pieces with different sizes and characteristics (?). ? found that the water level increase was logarithmically related to the reduction of cross sectional area. ? also saw a clear relation between water levels with obstruction area, but the relation was more irregular due to different wood sizes and characteristics. Although both studies showed an increase in water level, they found a minimal flood risk caused by wood in rivers.

Other studies on the hydraulic effects of wood used the measured water level increase to quantify the hydraulic roughness caused by wood (????). ? showed that the friction coefficient controlled by wood decreases with increasing discharges in the flume. They attribute the decrease in wood-induced friction with discharge to the decrease in turbulence during submergence of the wood patches. Thus, the friction coefficient in a stream with wood patches decreases when discharge and water levels increase, which was also discussed based on field studies (???). These findings show that backwater effects are not only related to the reduction of cross-section area, but also to friction and discharge. These relations are not extensively studied, and were identified as a knowledge gap by ?. ? argues that researchers are unable to quantitatively estimate the magnitude of flow resistance and obstruction associated with mobile or stable large wood at the segment scale, and that there is no widely applicable technique to quantify these effects. One of the reasons for this knowledge gap is that it is currently impossible to accurately measure the friction and cross sectional area reduction of wood in the field (?). In short, it is poorly understood how wood patches with different obstruction ratios and hydraulic roughness respond to discharge variation.

The aim of this study is to better understand how the wood-induced backwater effect response depends on wood obstruction area, enhanced hydraulic roughness and discharge. We propose a conceptual model that captures backwater development caused by wood patches in terms of obstruction ratio and hydraulic roughness, which can serve as a widely ap- 
plicable tool in water resource management. We analyse the sensitivity of wood patch characteristics, such as wood height, width and friction and the wood patch shape and stream geometry. We validated our model with the data from four lowland streams with different wood patch and stream geometries. In the field analysis, we investigated the relation between water levels and discharge with and without wood patches, and the temporal variation of this relation. In addition, we calibrated the model using a field study. We show that the water level increases with increasing discharge up to a maximum, after which the water level decreases with increasing discharge. The conceptual model is able to predict the discharge at which the water level changes from increasing to decreasing based on the wood and channel geometry. Hence, the model may help in the construction of wood patches such that target flood levels are achieved, and, in doing so, can serve to optimize the hydrological and ecological potential of streams and rivers.

\subsection{Model}

A backwater effect model was used to understand interplay between cross sectional reduction and enhanced friction. We studied the sensitivity of wood height, width and friction and different channel and wood geometries in relation to the reaction of water level to discharge. Wood in streams can be modelled using physics-based, empirical or conceptual models. Physics-based models attempt to incorporate all involved physical processes, aiming to resolve the detailed flow patterns (???????). Therefore, these models require detailed input data for the wood elements, the stream geometry and the flow velocity, which are not always available at large spatial and temporal scales (?). As opposed to physics-based models, empirical models require little input data but are often based on information from a limited number of sites (??). Empirical models lack a physical basis and are site specific, consequently, limiting their generalizability. Here, we introduce a conceptual model with the intention to combine the best of both worlds, i.e., to include the first-order physical processes while keeping the input data requirements minimal.

We consider one-dimensional, steady flow conditions where the wood patch is represented as an impermeable obstruction in the stream. Hence, the flow velocities inside the wood patch are many times smaller than they are in the area without wood (????). The wood patches become addition- 
ally less permeable over time because of clogging of small branches, vegetation and sediment. ? however showed that the assumption of impermeability can result in an overestimation of the drag force of 10 to 20 percent. The overestimation of water levels is much less, since the water level is roughly proportional to the square root of the drag force (e.g. ??). The impermeability of wood patches is thus a valid first order assumption. In addition, ? and ? showed that at the channel reach scale the flow resistance is predominantly affected by the blockage area by vegetation. These findings encourage the focus on the obstruction ratio and hydraulic resistance for reach scale studies. Regarding hydraulic resistance, we adopt the Manning's coefficient. We further assume a gradual transition between water levels on both sides of the wood patch, such that gradually varied flow equations apply and the wood patch is not a control point in a hydraulic calculation. Since we are interested in the effects of wood patches that only partly blocking the stream width, we consider this assumption valid. It is important to consider the above-discussed assumptions when using the model.

In terms of hydraulic theory, a wood patch in a lowland stream with a mild bed slope locally elevates the equilibrium depth. Along the length of the patch, the water surface is lower than the equilibrium depth, and the water surface profile is classified as " $M_{2}$ " (Figure 2.1). Upstream of the patch, the depth is above the equilibrium depth, and a " $M_{1}$ " water surface profile is present. Downstream of the patch, the flow assumes equilibrium depth. The model assumes the cross-section geometry and hydraulic roughness to be uniform in the streamwise direction and only changes in cross sectional area and friction at the location of a wood patch (Figure 2.2a). The channel and wood geometries are expressed in $x$ (longitudinal), $y$ (transverse) and $z$ (vertical) coordinates. The origin corresponds to the deepest point of the cross-section, at the left bank of the wood patch (Figure 2.2b). The $y_{L}(h)$ and $y_{R}(h)$ are the horizontal distances from the midpoint to the left and right banks at water level $h$, respectively (Figure $2.2 \mathrm{~b})$. The width, $B(\mathrm{~m})$, is obtained from:

$$
B(h)=y_{R}(h)+y_{L}(h),
$$

and the cross sectional area, $A(\mathrm{~m})$, is obtained from (Figure 2.2c):

$$
A(h)=\int_{0}^{h} B(z) d z
$$




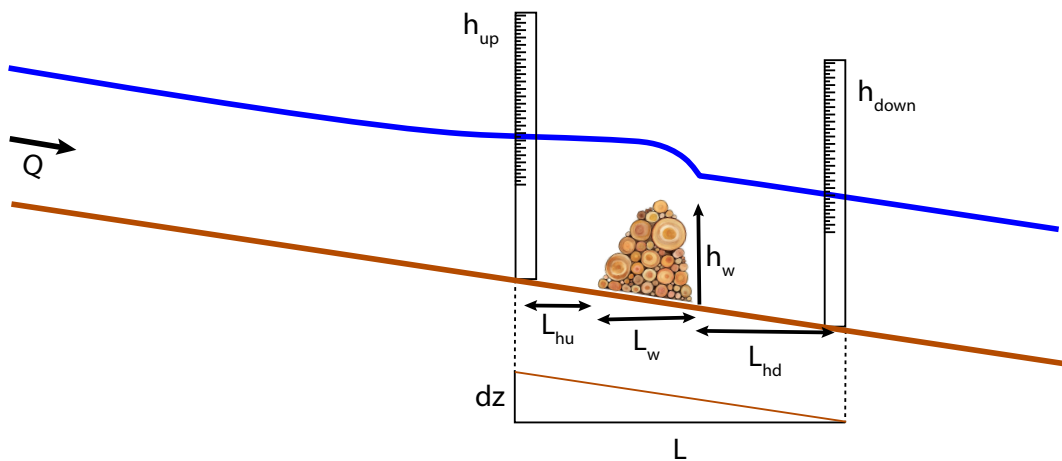

FIGURE 2.1. Illustration of the experimental set-up. The backwater effect was measured with the water levels upstream $\left(h_{u p}\right)$ and downstream $\left(h_{\text {down }}\right)$ of the wood patch for a range of discharges $(Q)$. During the field campaign, we measured the wood height $\left(h_{w}\right)$ and the length of the wood $\left(L_{w}\right)$. The bed slope $\left(d z L^{-1}\right)$ and distances from the wood patch to the upstream $\left(L_{h u}\right)$ and donwstream water level measurement $\left(L_{h d}\right)$ were obtained by, respectively, available bathymetry measurements and by the position of wood and the water level measurements.

The wetted perimeter, $P(\mathrm{~m})$, is calculated according to (Figure $2.2 \mathrm{~d}$ ):

$$
P(h)=\int_{o}^{h}\left(\sqrt{1+\left(\frac{d y_{L}}{d h}(z)\right)^{2}}+\sqrt{1+\left(\frac{d y_{R}}{d h}(z)\right)^{2}}\right) d z,
$$

and the hydraulic radius, $R(\mathrm{~m})$, according to:

$$
R(h)=\frac{A(h)}{P(h)} .
$$

Based on the geometry, the model determines whether the water level is in contact with wood on the right or left bank. Values of $w_{L}(z)$ and $w_{R}(z)$ are set to 1 when at elevation $z$, respectively the left bank or the right bank is covered with wood (Figure 2.2e). Otherwise, these parameters are set to 0 . The wetted perimeter of the area covered by wood, $P_{w}(\mathrm{~m})$, is obtained as:

$$
P_{w}(h)=\int_{o}^{h}\left(w_{L}(z) \sqrt{1+\left(\frac{d y_{L}}{d h}(z)\right)^{2}}+w_{R}(z) \sqrt{1+\left(\frac{d y_{R}}{d h}(z)\right)^{2}}\right) d z
$$



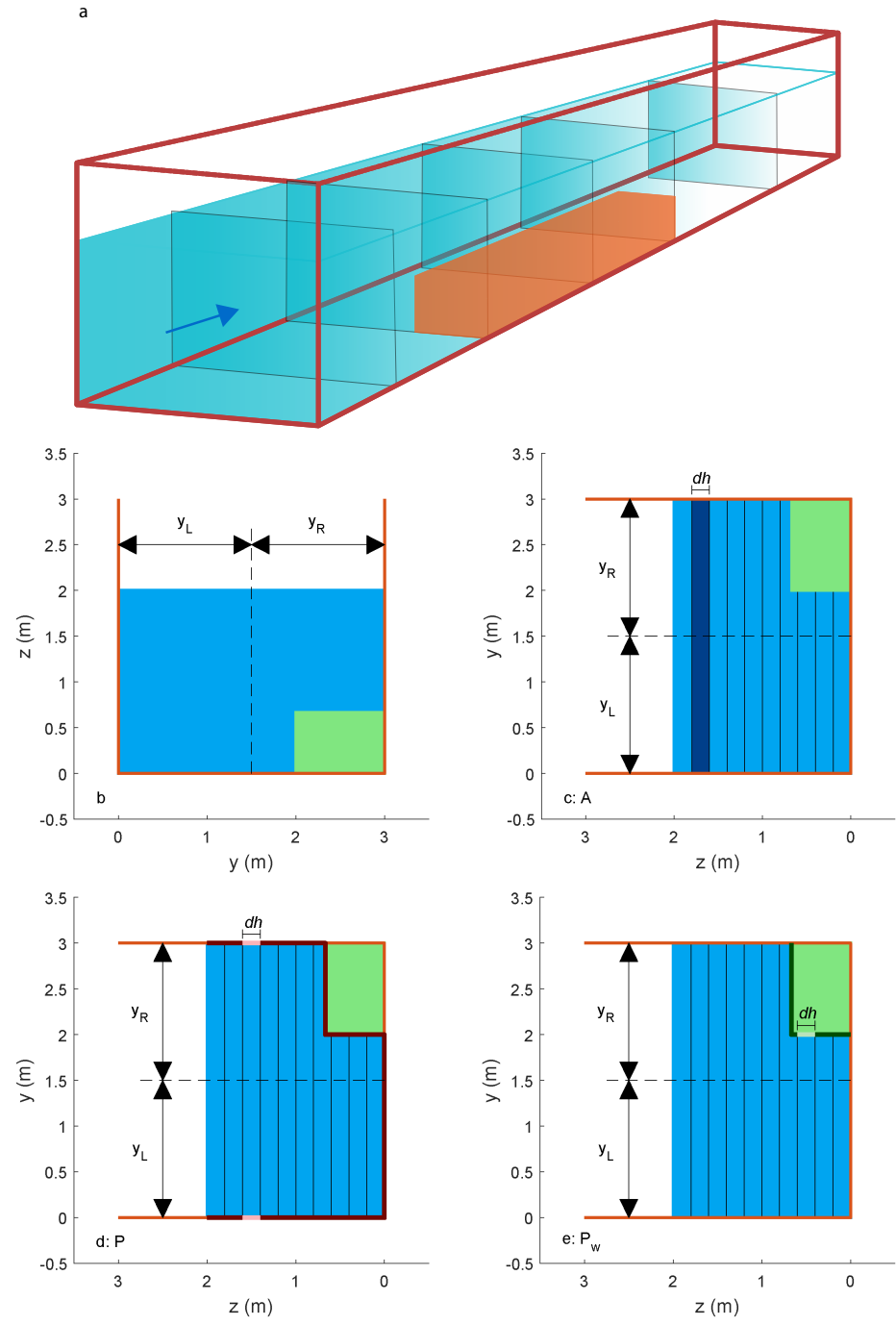

FIGURE 2.2. Illustration of the backwater effect model. The model simplifies reality by constructing multiple cross sections in the longitudinal direction (Panel a). These cross sections may contain wood. The origin of the cross-section and $y_{L}$ and $y_{R}$ are illustrated in Panel $\mathrm{b}$. The calculation of cross sectional area and wetted perimeter are illustrated in Panel $\mathrm{c}$ and Panel d, respectively. The calculation of the wetted perimeter of the area covered by wood is shown in Panel e, in which $w_{L}$ is 0 for all $z$-values and $w_{R}$ is only 0 for $\mathrm{z}$-values larger than $0.8 \mathrm{~m}$. 
which is used to establish the wood fraction as in:

$$
f_{\text {wood }}(h)=\frac{P_{w}(h)}{P(h)} .
$$

The wood fraction is used to calculate the effective Manning's coefficient, $n_{\text {eff }}\left(\mathrm{s} \mathrm{m}^{-1 / 3}\right)$ :

$$
n_{\text {eff }}(h)=f_{\text {wood }}(h) n_{\text {wood }}+\left(1-f_{\text {wood }}(h)\right) n_{\text {stream }} .
$$

The average flow velocity over the cross section, $u\left(\mathrm{~m} \mathrm{~s}^{-1}\right)$, is calculated with the specified total discharge, $Q\left(\mathrm{~m}^{3} \mathrm{~s}^{-1}\right)$ :

$$
u(h)=\frac{Q}{A(h)},
$$

The Froude number, $\operatorname{Fr}(-)$, is calculated as:

$$
F r(h)=u(h) \sqrt{\frac{B(h)}{g A(h)}},
$$

and the friction slope, $S_{f}\left(\mathrm{~m} \mathrm{~m}^{-1}\right)$, reads:

$$
S_{f}(h)=\frac{\left(n_{e f f}(h) Q\right)^{2}}{A(h)^{2} R(h)^{4 / 3}} .
$$

With the aid of the friction slope and the Froude number, the water slope $\left(\mathrm{m} \mathrm{m}^{-1}\right)$ is determined as:

$$
\frac{d h}{d x}=\frac{S_{0}-S_{f}(h)}{1-F r^{2}(h)},
$$

where $S_{0}$ is the bed slope $\left(\mathrm{m} \mathrm{m}^{-1}\right)$ and $g$ is the gravitational acceleration $\left(\mathrm{m} \mathrm{s}^{-2}\right)$. The downstream water level corresponds to equilibrium water depth, $\mathrm{h}_{n}$ :

$$
h_{n}=S_{0}-\frac{(n Q)^{2}}{A^{2}(h) R^{4 / 3}(h)} .
$$

The elevation above equilibrium water depth corresponds to the woodinduced backwater effect. 


\subsection{Study area}

In the field study, we investigated the water level response to discharge variation. Four field sites in the Netherlands were studied and referred to as Leerinkbeek, Tungelroysebeek, Tongelreep and Ramsbeek. These streams are located in the Rhine-Meuse lowland, which is an alluvial basin composed of clayey and/or sandy soils. These areas were selected because they are located in agriculture and nature areas with few buildings in the neighbourhood. Floods in these areas will have limited impacts, while the natural processes and effects can be studied. To measure the backwater effects, the local water boards installed discharge measurement gauges and two level gauges upstream and downstream of the wood patches. The gauges measured discharges and water levels hourly. In addition, the bed slope, geometry of the stream and length and height of the wood patches were measured.

The geometries of the streams are shown in Figure 2.3. The left side of the figure shows constructed cross-sectional areas from bathymetry measurements using a handheld real-time kinematic (RTK) GPS with a total station before the wood was placed in the streams. The bed slope was calculated by the average bed slope established based on cross-section information from the Tungelroysebeek and Tongelreep. For the Leerinkbeek and Ramsbeek, the bed slope was approximated by the water level slope measured prior to wood placement under uniform flow conditions, because too few cross-sectional areas were available to reliably estimate the bed slope.

The left side of Figure 2.3 shows digital elevation maps (DEMs) based on a drone survey using stereo-photography. These DEMs were available for three of the four research sites. In case of the Tongelreep, it was prohibited to fly a drone because of the neighbouring airport. The composition of the wood patches was as follows.

- The wood patch in the Leerinkbeek was constructed at one side of the bank and consists of two or three tree trunks. The tree roots were about 0.75 meter by 0.75 meter with a trunk of $0.5 \mathrm{~m}$. These trunks were piled up by large branches of $2 \mathrm{~m}$ in length and a diameter of $10 \mathrm{~cm}$. The trunks and branches were anchored to the bed or banks to prevent movement.

- The wood patch in the Tungelroysebeek was constructed following a protocol by?, in Dutch. The protocol prescribes to place the branches 

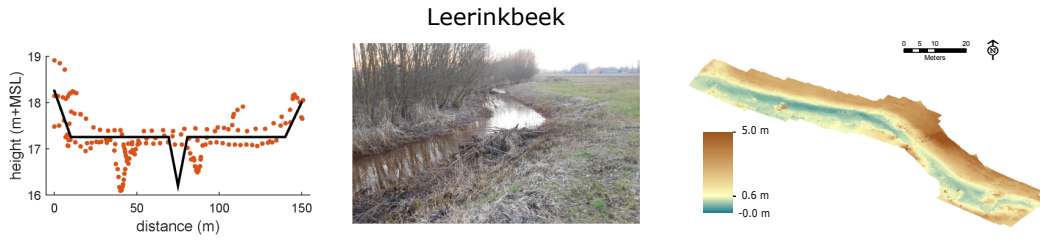

Tungelroysebeek
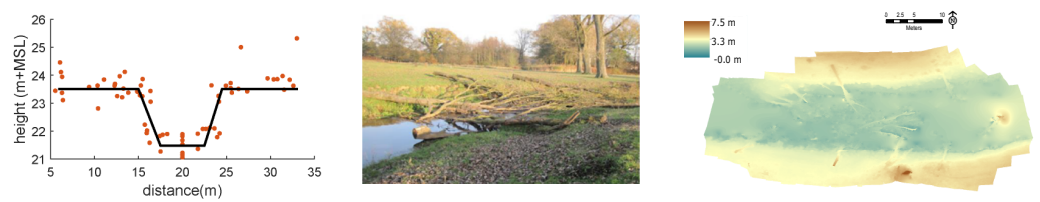

Tongelreep
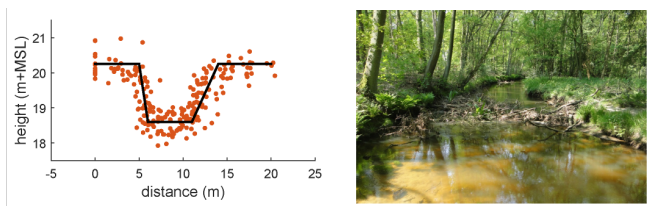

Ramsbeek
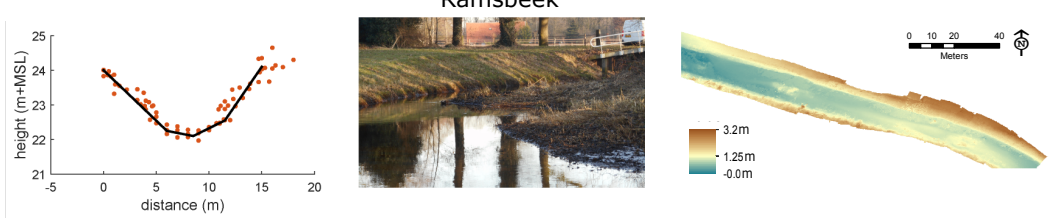

FIGURE 2.3. The bathymetry of the streams (right), the photos of the wood patches (middle) and the digital elevation of the studied streams (left). The orange dots are the measured cross-sections in the reach of the wood patches before the placement of the wood patches. The black lines are cross-sections used for the calibration.

of the tree from the channel bank into the stream, such that it covers more than $75 \%$ of the stream width. The trees were positioned such that the flow velocity was scattered across the stream width. It was advised to use a tree with a trunk diameter of more than $20 \mathrm{~cm}$ and with branches with a diameter of more than $5 \mathrm{~cm}$. The trees were anchored in the bank to prevent movement.

- The wood patch in the Tongelreep was constructed with branches of $9 \mathrm{~m}$ length and with a diameter of $10 \mathrm{~cm}$ including twigs. These 
TABLE 2.1. Overview of the average discharge, $Q_{a}$, average yearly discharge maximum, Qay, slope and length of the stream, and length, height and width of the wood patches of the four studied streams. The last column indicates the bankfull water level without wood in the studied streams.

\begin{tabular}{l||c|c|c|c|c|c|c|c|c} 
Name & $\begin{array}{l}Q_{a} \\
\left(\mathrm{~m}^{3} \mathrm{~s}^{-1}\right)\end{array}$ & $\begin{array}{l}Q_{a y} \\
\left(\mathrm{~m}^{3} \mathrm{~s}^{-1}\right)\end{array}$ & $\begin{array}{l}S_{0} \\
\left(\mathrm{~m} \mathrm{~km}^{-1}\right)\end{array}$ & $\begin{array}{l}S_{0} / L \\
\left(\mathrm{~km}^{-1}\right)\end{array}$ & $L(m)$ & $L_{w}(\mathrm{~m})$ & $h_{w}(m)$ & $B_{w}(m)$ & $h_{b f}(m)$ \\
\hline Leerinkbeek & 0.50 & 4.2 & 0.57 & 0.11 & 208 & 110 & 0.5 & 2.22 & 1.20 \\
Tungelroysebeek & 0.83 & 5.0 & 0.34 & 0.37 & 1289 & 242 & 1.72 & 6.27 & 2.02 \\
Tongelreep & 1.14 & 3.8 & 0.53 & 0.40 & 695 & 693 & 0.94 & 4.09 & 1.65 \\
Ramsbeek & 0.48 & 3.0 & 0.14 & 0.02 & 140 & 100 & 0.9 & 4.01 & 1.90
\end{tabular}

branches covered $75 \%$ of the stream width and were anchored into the bed material.

- The wood patch in the Ramsbeek was constructed with branches of $2 \mathrm{~m}$ with a diameter of $3 \mathrm{~cm}$ intertwined and stacked on top of each other. The wood patch was fixed by anchoring the intertwined branches to the bed.

The anchoring of the patches prevents wood transport and, therefore, avoids wood jams. The permeability will not change with discharge because large wood pieces are not able to float. The smaller wood pieces, however, were collected from the wood patches shortly after insertion, resulting in more dense and less permeable patches (see photos in Figure 2.3). In reality, every wood pile is different. We have decided to simplify the wood configuration for calibration by using the average width and height of the wood patch constructed from the drone survey. The studied wood patches had a length between $100 \mathrm{~m}$ and $700 \mathrm{~m}$ in the various streams (Table 2.1). These patches consist of multiple wood piles of different lengths. The width and the height of the wood patches ranges from 2.22 to $6.27 \mathrm{~m}$ and 0.5 to $1.72 \mathrm{~m}$, respectively.

\subsection{Model application approach}

The model introduced in Section 2 was used to analyse the sensitivity of backwater effect to the channel geometry and details of the wood configuration, and to calibrate the model with the field experiments. For the sensitivity analysis, we schematized the channel geometry as rectangular, triangular and v-shaped cross-section (Figure 2.4). Similarly, we schema- 
TABLE 2.2. Manning's coefficients of the uncovered and the wood-covered parts of the stream, derived from model calibration.

\begin{tabular}{l||c|c} 
Name & $\begin{array}{c}n_{\text {stream }} \\
\left(\text { sm }^{-1 / 3}\right)\end{array}$ & $\begin{array}{l}n_{\text {wood }} \\
\left(\mathrm{sm}^{-1 / 3}\right)\end{array}$ \\
\hline Leerinkbeek & 0.025 & 0.1 \\
Tungelroysebeek & 0.03 & 0.045 \\
Tongelreep & 0.025 & 0.025 \\
Ramsbeek & 0.025 & 0.075
\end{tabular}

tized the wood obstruction area in the cross-sections as series of rectangles and triangles at one of the banks. The channel geometry was selected by a width of $3 \mathrm{~m}$, a $n_{\text {stream }}$ of $0.04 \mathrm{~s} \mathrm{~m}^{-1 / 3}$, a bed slope of $0.2 \times 10^{-4}$ and a wood length of $16.5 \mathrm{~m}$. The discharge varied between 0.25 to $4 \mathrm{~m}^{3} \mathrm{~s}^{-1}$. The default setting of the wood patches was the wood width of $50 \%$ the stream width and the wood height equal to the wood width. The Manning's coefficient for the wood patch $\left(n_{\text {wood }}\right)$ was 5 times the Manning's coefficient in the rest of the stream $\left(n_{\text {stream }}\right)$. To consider the sensitivity of these settings, we varied the wood width with $25 \%, 50 \%$ and $75 \%$ of the stream width. The wood height was varied between 0.5 to 1.5 times the wood width. The $n_{\text {wood }}$ was varied from equal to, 2.5, 5, 7.5 and 10 times the $n_{\text {stream }}$.

To reproduce field measurements, we composed the $n_{\text {stream }}$ based on discharge and water level measurements collected prior to insertion of wood (Table 2.2). The other stream characteristics were measured in the field (Table 2.1). The $n_{\text {wood }}$ was then calibrated using measurements after insertion of the wood patches.

\subsection{Results}

Using the model described in Section 2, the effects of wood obstruction for a variety of cross-section configurations were studied. The effect of changing width, height and roughness of the wood patch in the rows and the effect of changing the obstruction area and the channel geometry for each of those configurations in separate columns is shown in Figure 2.4. The width of the wood patch has the strongest influence on the water level drop over the wood patch in response to discharge increase, and this relation predominately affects the highest water level drop. When the width of 
the wood area increases, the water level drop increases more strongly with discharge. The height of the wood area does not influence the maximum water level drop, but it does influence the discharge at which the water level drop is at its maximum. As expected, a higher roughness coefficient results in an increase in the water level drop.

The first four configurations in Figure 2.4 show rectangular cross- section geometries of the channel, with wood patch shapes of various types. For these cases, the sensitivity analysis shows that the obstruction area is a parameter that significantly influences the water level drop. It increases with discharge when the top of the obstruction area corresponds to the bank height, and reaches a local maximum when the obstruction area remains below the bank height (Figure 2.4). The strongest water level drop was found for the rectangular obstruction area representing wood. A comparison between the fourth configuration with the second and third configurations shows that the shape of the wood area has a stronger effect than the obstruction area on the water level drop.

The cross-section geometry of the channel was changed in the last three configurations in Figure 2.4. The fifth and sixth configuration shows the same trapezoidal channel geometry, with the wood characteristics similar to those of the second and third configuration. The last configuration shows a v-shaped geometry with the wood on one side. The fifth and sixth configuration show the same backwater effect response as the second and fourth configuration, with the water levels reductions being about $33 \%$ higher, which is not surprising as the cross-section is $17 \%$ smaller than the rectangular cross-section. For the v-shaped configuration, a small discharge of $0.25 \mathrm{~m}^{3} \mathrm{~s}^{-1}$ is enough to reach the top of the wood area. Beyond this discharge, the backwater effect decreases with increasing discharge.

The development of the water level difference over time is compared for each of the four experimental sites (Figure 2.5). The black line is the bed slope and the crosses are the measurements after placement of the wood patches. For all streams, the water level drop over the wood patch increases with discharge, up to a maximum (Figure 2.5). When the discharge increases beyond this level, the water level drop declined to values that eventually correspond to the situation without wood, as shown for the Leerinkbeek. The maximum water level drop over the patches differs between the sites, and so does the rate of water level reduction for discharges beyond the maximum (Table 2.3). Qualitatively, the initial water level increase and subsequent decrease was similar for the different streams, but the discharge at which the maximum water level drop occurred ranges 

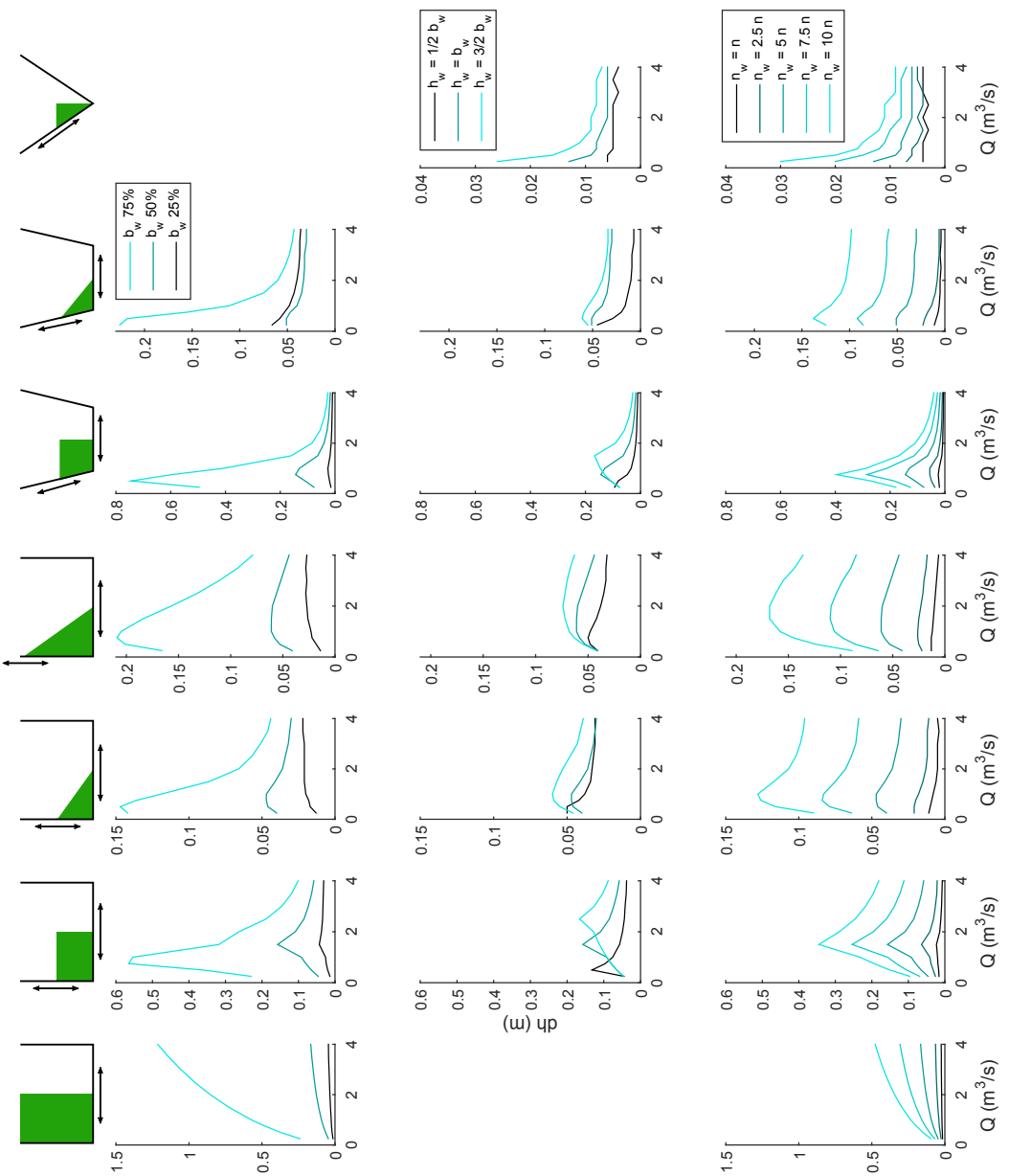

(w) чр

FIGURE 2.4. Model sensitivity to patch and channel characteristics. The obstruction width is changed in the first row, the obstruction height in the second row and the Manning's coefficient in the last row. The obstruction height in the first column is equal to the stream bank and therefore a panel in the second row is absent. 
TABLE 2.3. Overview of the field observations in the first year; $Q_{\operatorname{maxh}}$, the discharge with the maximum water level drop (first column), the water level drop increase from almost no discharge to the discharge with the maximum water level drop (second column) and the water level drop decrease from the discharge with the maximum water level drop to the maximum measured discharge (third column).

\begin{tabular}{l||c|c|c} 
Name & $Q_{\operatorname{maxh}}\left(m^{3} s^{-1}\right)$ & $\Delta h \uparrow(m)$ & $\Delta h \downarrow(m)$ \\
\hline Leerinkbeek & 0.17 & 0.17 & 0.08 \\
Tungelroysebeek & 0.8 & 0.16 & 0.05 \\
Tongelreep & 1.36 & 0.17 & 0.07 \\
Ramsbeek & 1.62 & 0.11 & 0.02
\end{tabular}

from 0.17 to $1.62 \mathrm{~m}^{3} \mathrm{~s}^{-1}$.

The water level drop decreased over time after placement of the wood patches (Figure 2.5). Figure 2.5 shows a reduction of the water level drop within two to five years in the studied streams. The reduction of the maximum water level drop was $0.17 \mathrm{~m}$ in the Leerinkbeek, $0.09 \mathrm{~m}$ for the Tungelroysebeek and $0.05 \mathrm{~m}$ for the Ramsbeek over two years (difference between the red and blue numbers in Figure 2.5). For the Tungelroysebeek, the water level drop increased by $0.04 \mathrm{~m}$ after the first year (Figure 2.5). In the fifth year after wood insertion, the water level drop decreased by $0.1 \mathrm{~m}$.

The model was calibrated to simulate the four field experiments. Figure 2.6 shows the representation of cross-sections and wood patch areas in the streams, as used in the calibration. In the same figure, the experimental data of the first year after the wood placement (blue dots) and the calibration results (red line) are shown. For the calibration, only the first year was used, as the water level drop becomes smaller over time. Table 2.3 shows the calibrated Manning's $n$ coefficients for the stream and wood. The calibration generally shows good agreement with the measurements. For the Tongelreep and Ramsbeek cases, the calibrations show more abrupt response changes than the measurements, especially for discharges from 0.5 to $1 \mathrm{~m}^{3} \mathrm{~s}^{-1}$ and from 2 to $2.5 \mathrm{~m}^{3} \mathrm{~s}^{-1}$ for the Tongelreep and for $1.5 \mathrm{~m}^{3} \mathrm{~s}^{-1}$ in the Ramsbeek. These discrepancies were likely caused by the simplification of the wood patches and stream bed. 

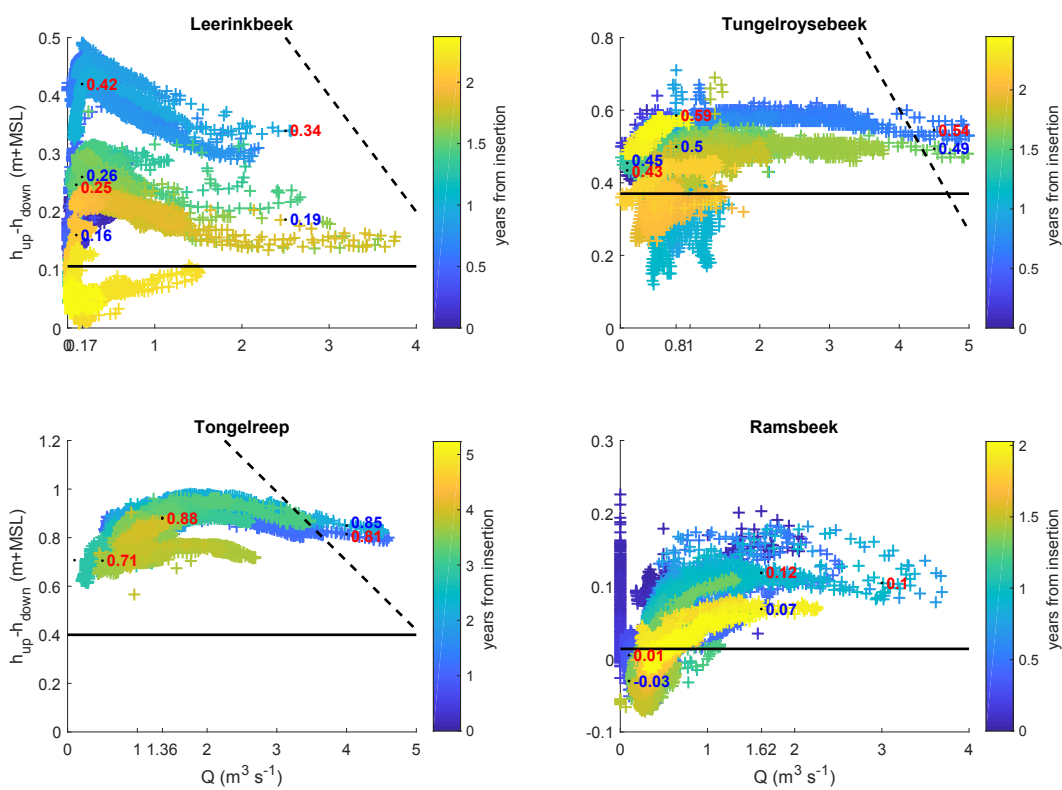

FIGURE 2.5. Dependence of the water level drop over wood patches on flow conditions. The black solid line indicates the water level drop before placement of the wood patches and the plusses indicate the measurements after placement of the patches. The color indicates the elapsed time after the placement of the wood. The red numbers show the average water level drop at the smallest and highest discharge and at the maximum water level drop in the first year after placement of wood. The blue numbers show the average water level drops for the years after the first year. The black dashed line indicates the bankfull situation. The right side of the dashed lines indicate local flooding.

\subsection{Discussion}

Both the field experiments and the model study show that the water level drop over the wood patches increases with increasing discharge until a maximum after which the water level drop decreases with increasing discharge. This relationship is influenced by varying hydraulic roughness and flow area with increasing discharge. When the water level is below the wood height, a small water level increase will result in a higher effective roughness and in a small increase the cross-sectional area. When the water level is above the wood top, a similar water level increase will result in a lower effective hydraulic roughness and in a larger cross-sectional area in- 

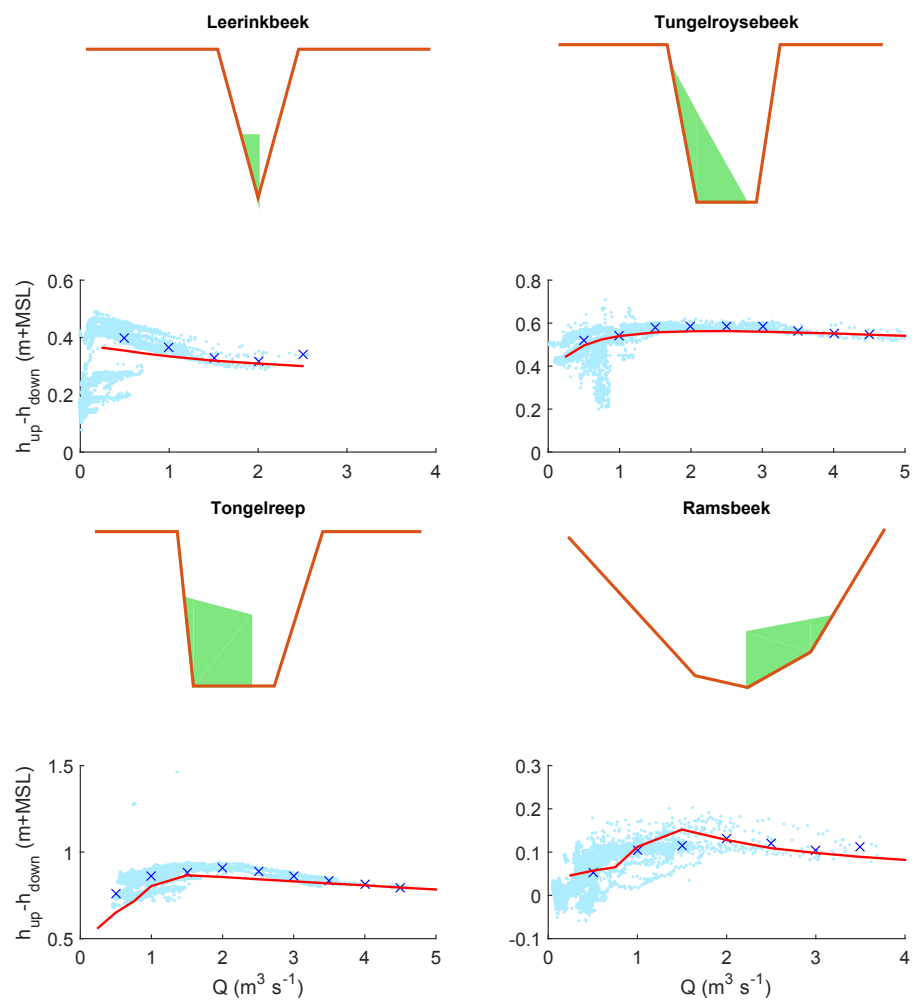

FIGURE 2.6. Calibration of the water level drop over the wood patches at the four experimental streams. The dots indicate the measurements after placement of the wood patches in the first year and the crosses are the average water level drop in steps of $0.5 \mathrm{~m}^{3} \mathrm{~s}^{-1}$ of discharge. The red line is the best fit through the crosses. The Manning's coefficient for the best fit is discussed in Table 2.3.

crease than for water levels lower than the wood height (Figure 2.7). This implies that if the discharge causes the water levels to exceed the wood height, the water levels decrease with increasing discharge. This interaction was also described in the sensitivity analysis and by?. The friction slope is decreasing with discharge according to the Darcy-Weisbach formula, because the squared velocity term is increasing more rapidly than the linear depth term (?). Furthermore, the reduction of water level increase as a response to discharge over time probably resulted from morphological adjustments of the stream bed and/or changes in wood con- 
figuration. From visual observations in the Tungelroysebeek thalweg (Figure 2.8), the wood was degraded especially at the average water level, which resulted in a reorientation of the wood at the bank and on the bed. Wood at the bank and bed resulted in a smaller conveyance area and additional obstructions at places where more shear was present.
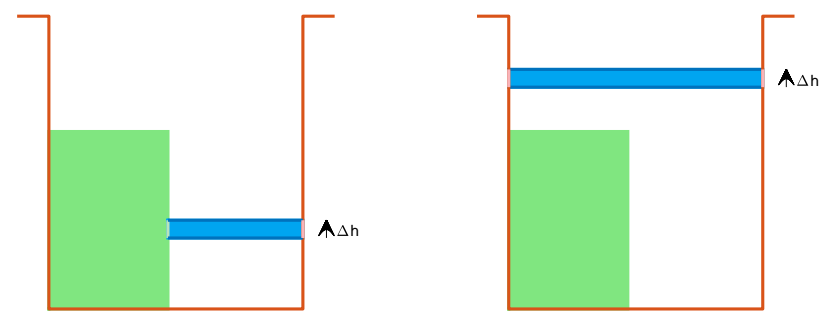

FIGURE 2.7. Conceptual cross-section illustrating the incremental increase of the wetted perimeter for a water level increase $\Delta h$. The wood patch is illustrated with the green color. The blue color indicates the wetted cross-sectional area increase and the light red and green colors illustrate the wetted perimeter in contact with the channel bed or the wood patch, respectively.
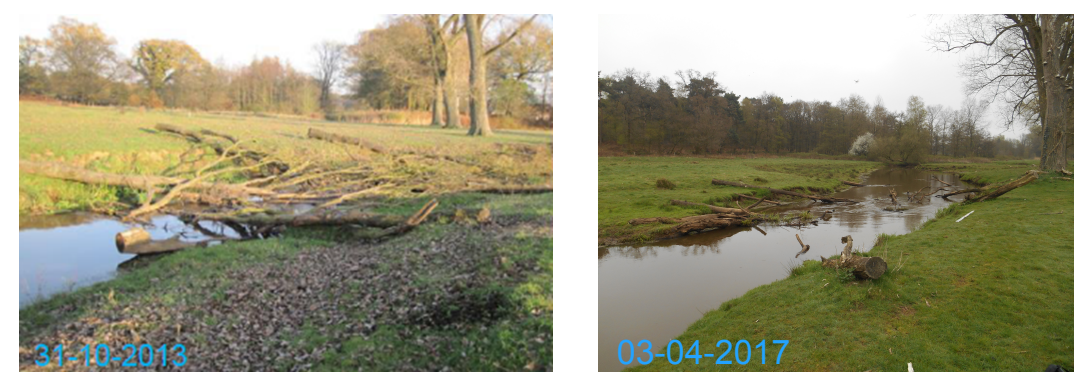

FIGURE 2.8. Morphological adaptions of a wood patch in three and half years at the Tungelroysebeek.

In the field experiments, we showed that backwater effects are significant after placement of wood in streams and even result in flooding. Unlike ?, we do not claim that wood in lowland rivers does not significantly affect flood levels. This study stresses that the exceedance of the flood lev- 
els are not only influenced by the width of the wood patch, but that the details of the wood obstruction area, channel geometry and amount of discharge all contribute. Just focussing on one element will not provide the necessary knowledge to make an informed decision on the placement of wood in streams. Although the conclusions are different from ?, the field observations and insights from the simple model are in agreement with previous laboratory, field and physical model studies. The backwater effect increases logarithmically with wood width, similar to the findings of ? and ?. The dependence of backwater effect on wood height has previously been established by studies focussed on the hydraulics of step-pool rivers (????). In addition, we also found a decrease of friction with increasing discharge based on the friction slope.

The model is made available as user-friendly html code along with this publication (doi:10.4121/uuid:55604c80-61d3-4c31-97e7-aald3e4c88af), and can readily be used to investigate the effects of any other type of setting and wood configuration. The model allows to quantify the backwater effects for different channel and wood geometries, and can be used to predict the effects in other rivers and natural conditions. The model is a generic tool for scientists and practitioners, who prepare the placement of wood in streams, to estimate the backwater effect that can be expected from alternative configurations. Wood has to be removed from streams only when it raises the water levels above the maximum allowable water levels. This management strategy can enhance the ecological and morphological effects of (lowland) streams. Similarly, the model can be employed to estimate the peak backwater level as a result of wood jams or beaver dams, provided that the basic model input is available.

\subsection{Conclusions}

Based on model simulations and field evidence, this study explains how wood-induced backwater effects are governed by discharge, wood patch characteristics and channel geometry. Wood in streams gradually increases the water level towards a wood patch, where the water level reduces to resume equilibrium depth downstream of the patch. This water level drop increases with increasing discharge, up to a maximum after which the water level drop decreases with discharge. The characteristics of this relationship depend on wood configuration and on channel geometry. The wood orientation and channel geometry may change over time, exerting an im- 
pact on the backwater response to discharge change. Significant morphological adjustments and wood degradation were observed within two to five years after wood placement.

A conceptual model is proposed to simulate the wood-induced backwater effect variation. Using the model, a sensitivity study of wood characteristics showed that the width of the wood is responsible for the peak in the backwater elevation, and the height of the wood configuration controls the discharge at which the highest backwater effect was observed. We conclude that the obstruction area and hydraulic roughness variation exert a similar influence on the backwater effect in streams. The model introduced herein can be employed by scientists and practitioners to allow for controlled insertion of wood in streams, without jeopardizing flood protection. 


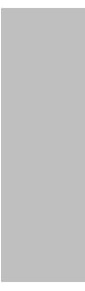


CHAPTER

3

Flow patterns and backwater effects in sharp lowland river bends

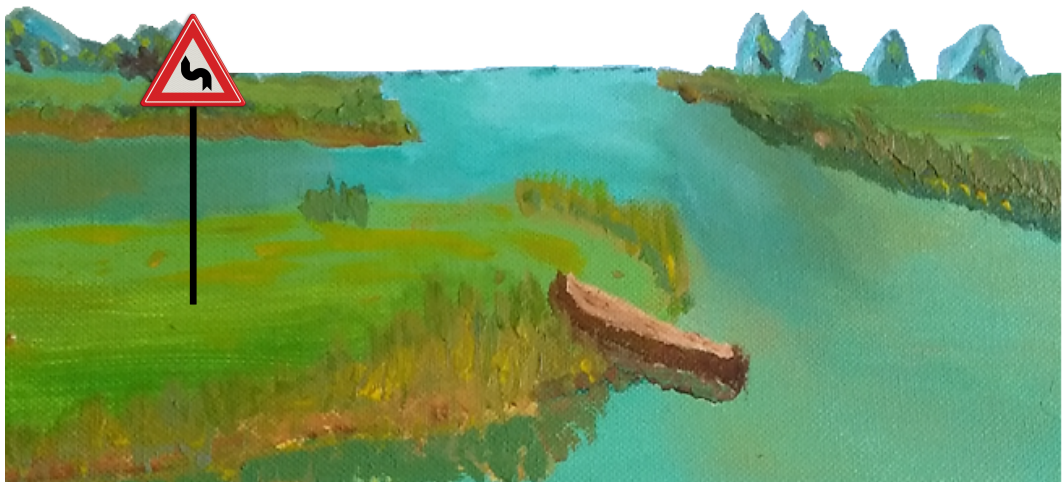

This chapter is based on: Geertsema, T. J., B. Vermeulen, A. J. Teuling and A. J. F. HoITINK, Transience of recirculation cells in sharp lowland river bends. 


\begin{abstract}
Horizontal flow recirculation is frequently observed in sharp lowland river bends. It arises from an adverse water level gradient, induced by curvature and/or a cross-sectional increase, which can reverse the flow where the flow is locally relatively weak. Both the flow strength and water surface topography change in time, and thus the horizontal flow recirculation may be unsteady. This study aims to better understand the stability of recirculation zones. We measured water levels and velocities at various discharge conditions in two sharp lowland bends in the Essche Stroom and Dommel Rivers, the Netherlands. The Essche Stroom showed similar flow patterns for similar discharge conditions. The Dommel River, on the contrary, showed two distinct flow patterns, one with and one without flow recirculation. With a simple model for bend flow by? and the one-dimensional depth-averaged momentum equation, we show that for the flow pattern without flow recirculation, the flow decelerates according to what may be expected from channel curvature and cross-section variation. For the flow pattern where flow recirculation is present, the model is less easily applicable. We discuss the delicate processes that may or may not result in flow reversal in the Dommel River, highlighting the instability of flow recirculation zones. The water surface topography substantially influences the flow patterns in bends, however, it is too small to be directly measured with standard instrumentation, and is only locally observed in the bends. Two and three dimensional effects, such as lateral redistribution of momentum and the interaction with scour holes, will influence the horizontal flow recirculation. These effects should be incorporated into the analysis to explain the unexpected transience of flow recirculation in the Dommel River.
\end{abstract}

\title{
3.1 Introduction
}

Horizontal flow recirculation is frequently observed in sharp river bends and at a range of scales (??????????). Strong curvature creates a lateral water surface gradient, causing an increase of water levels in the outer bend and a decrease in the inner bend. The lateral gradient allows the flow to curve through the bend, creating a pressure force balancing the centripetal force (?). Longitudinal change in the lateral water surface gradient causes the water surface to increase in longitudinal downstream direction, creating adverse pressure gradients. At the entrance of the river bend, the curvature and thus the lateral water surface gradient increases, resulting in an 
adverse pressure gradient that peaks at the outer bank. At the bend's exit, the curvature and thus the lateral water surface gradient decrease, resulting in an adverse pressure gradient at the inner bank. In addition to flow curvature, cross-section variation can directly cause an adverse pressure gradient, based on Bernoulli's principle (?)

Experiments show that the recirculation zones do not emerge, when an adverse pressure gradient is present (?). At the river scale, there exists little information about the persistence of horizontal flow recirculation. ? showed that changes in discharge conditions have a large influence on flow recirculation and sedimentation. However, they did not discuss the reasons for varying flow patterns. When the downstream flow is too weak, the centripetal force may not be strong enough to create a substantial adverse pressure gradient. When the downstream flow is strong up until close to the bank, the flow may decelerate without reversing (??). ? shows that strong flow near the outer river bank can suppress the flow recirculation zone. Moreover, the secondary flow causes the downstream flow magnitude to concentrate more strongly near the outer bank, and to disperse from the inner bank. This results in a suppressing factor for flow recirculation at the outer bank, and promotes the propensity for flow recirculation near the inner bank. A local cross-sectional area increase, which typically occurs in sharp bends (?), promotes flow reversal both in the inner and in the outer bend.

This study investigates the effect of discharge conditions on the horizontal flow recirculation at two lowland river bends. We aim to understand if horizontal flow recirculation in lowland river bends are persistent, and evaluate the degree in which the simple model by ? can explain observations. We performed a field campaign in which the water levels and flow velocities were measured at the Essche Stroom and the Dommel Rivers, the Netherlands. Section 3.2 describes the field campaign in detail. In the subsequent Results section, we will show that the horizontal flow recirculation cell in one of the bends is transient: with increasing discharge, the cell that emerges at low flow vanishes, and then reappears at the highest flow conditions. In the Discussion section, we reason how far the existing understanding allows to explain the observations, and in Section 3.5 conclusions are drawn. 


\subsection{Field experiment and data}

The Essche Stroom is a large tributary of the Dommel River. The confluence is located $2 \mathrm{~km}$ and $16 \mathrm{~km}$ from the investigated sharp bends in the Essche Stroom and the Dommel, respectively. The Essche Stroom has a lower average discharge, amounting to $4.7 \mathrm{~m}^{3} \mathrm{~s}^{-1}$, versus $7.2 \mathrm{~m}^{3} \mathrm{~s}^{-1}$ in the Dommel River, but in the course of the wet season, the peaks have the same order of magnitude (Figure 3.1). The discharge time series were measured by the water board "De Dommel" with a frequency of 10 minutes. The Essche Stroom has a mildly curved bend $20 \mathrm{~m}$ upstream. Over $250 \mathrm{~m}$ upstream of the bend subject to investigation the Dommel River, the channel is straight. The maximum curvature of the bend in the Essche Stroom is 1.9, and of the bend in the Dommel River is 3.7. The average widths of the Essche Stroom and the Dommel River are, respectively, $19 \mathrm{~m}$ and $22 \mathrm{~m}$, and the maximum depths are, respectively, $4.9 \mathrm{~m}$ and $4.4 \mathrm{~m}$ (Figure 3.2). The Essche Stroom has a smaller cross-sectional area upstream of the bend, however, the cross-sectional area is comparable with the Dommel River in the bend due to a larger relative scour hole.

During the field campaign, we measured the water levels with a frequency of 15 minutes with Keller sensors. These sensors measure both the water pressure as well as air pressure. Two of the water level measurements were placed upstream of the bend at the bank connected with the inner bend. One of the water level measurements was located in the inner bend and one in the outer bend. The last water measurement was located downstream at the bank connected to the inner bend. In addition to the continuous water level measurements, we also measured the water levels at the bank at the Essche Stroom and the Dommel on the $2^{\text {nd }}$ of February 2018 and the $15^{\text {th }}$ of May 2018, using a handheld real-time kinematic (RTK) GPS. The measurement inaccuracy of the Keller sensors and RTK-GPS is 1 $\mathrm{cm}$. The trees in the outer bank of the Dommel prevented that water levels at the outer bank could be measured with the RTK-GPS. The water level measurements were referenced using the water level measurements at the bank. Since the trees prevented GPS-measurements at the outer bank, the water level measurement could not be referenced at the outer bank of the Dommel.

In addition to the water level measurements, we measured the flow velocities in the Essche Stroom on the $30^{\text {th }}$ of January 2018 and the $12^{\text {th }}$ of February 2018, during discharges of 7.2 and $8.1 \mathrm{~m}^{3} \mathrm{~s}^{-1}$, and in the Dommel on $9^{\text {th }}$ and $16^{\text {th }}$ of January 2018 , during discharges of 9.3 and $13.0 \mathrm{~m}^{3}$ 
$\mathrm{s}^{-1}$. We measured the flow velocity in transverse cross-sections using a Teledyne RDI StreamPro ADCP. At each cross-section, we took at least ten transects to filter out the turbulence effect in the post-processing. Trees presented major obstacles for the ADCP measurements, which resulted in fewer measurements in the Dommel River during ADCP campaigns. Last but not least, short $(30 \mathrm{sec})$ movies were taken after each measurement day, and surface flow profiles were later extracted using PIVlab (?).

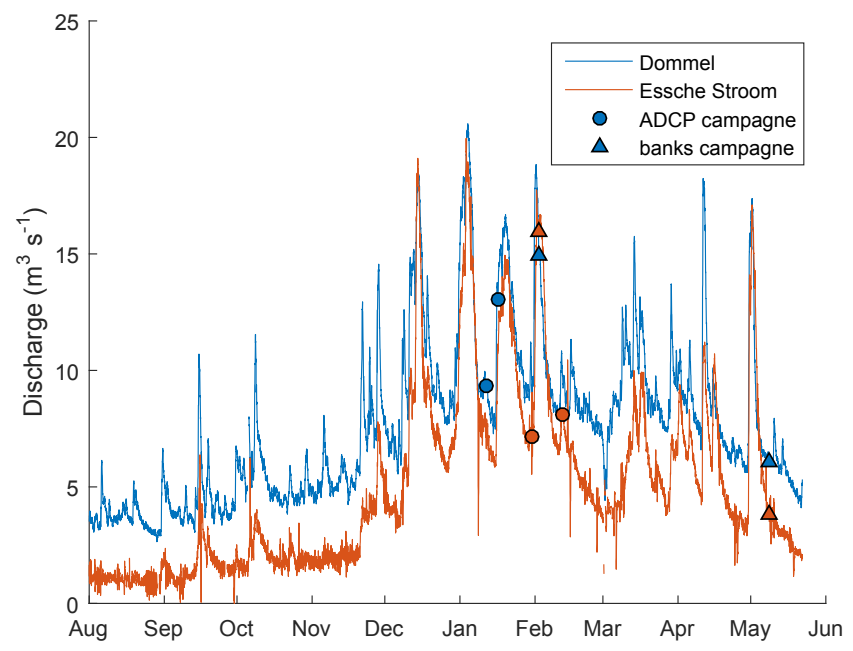

FIGURE 3.1. Discharge dynamics during the study period. The Essche Stroom and Dommel Rivers are indicated with the orange and blue lines, respectively. The timing of the ADCP campaign in the Essche Stroom and Dommel River are indicated by circles, and the timing of the bank campaign by triangles.

\subsection{Results}

\section{Water level measurements}

Based on the Bernoulli principle, increasing flow velocities and energy losses cause water levels to decrease. Since recirculation zones could result in additional energy losses (?), we investigate the longitudinal water level profile. The longitudinal water level measurements along the bank 

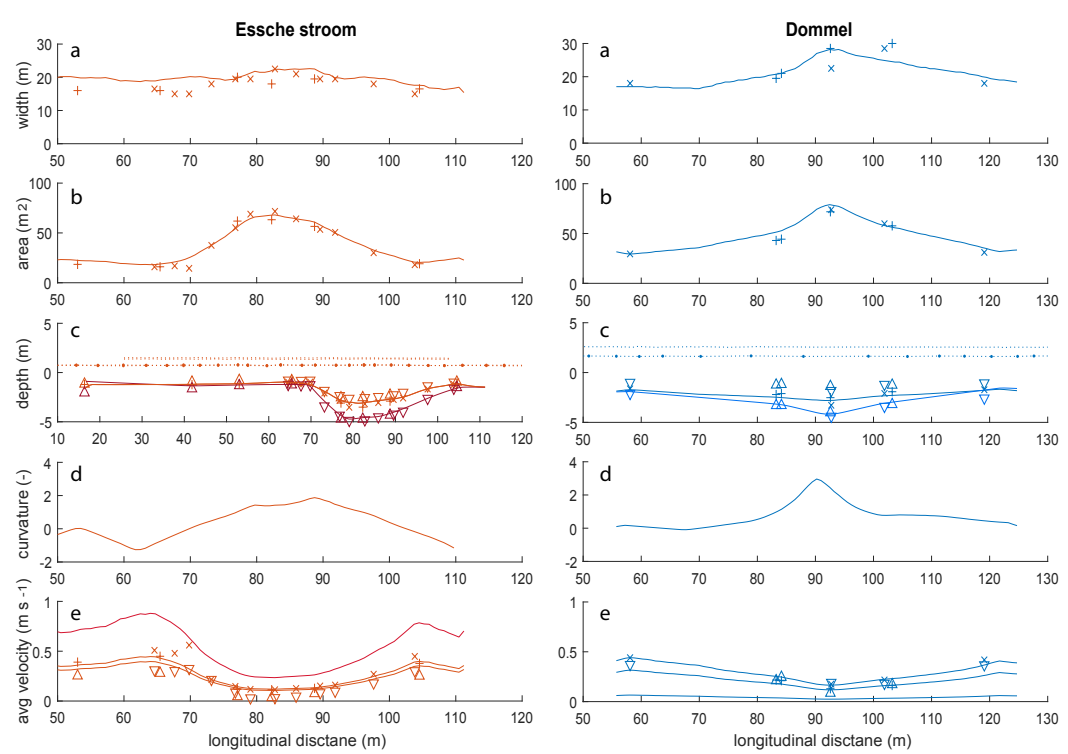

FIGURE 3.2. Geometries of the Essche Stroom and Dommel Rivers. The cross symbols indicate the ADCP measurements during the lowest discharge and the plus symbols during the highest discharge. The lines indicate the interpolation over the bend using the ADCP measurements. Panel c shows the cross-sectional averaged depth by dividing the area with the width and the maximum crosssectional depth. The triangles are the measured width averaged and maximum depths. The dots indicate the average through the measurements of the water level at the bank. Panel d shows the curvature along the streamwise direction and panel e the cross-sectional average velocity. The cross-sectional average velocities are determined by discharge divided by the area. The downward triangles are the measured averaged cross-sectional velocities during the lowest discharge and the upward triangles during the highest discharge.

show a standard deviation of $0.03 \mathrm{~m}$ over a water level difference of $0.04 \mathrm{~m}$ in the Dommel River (Figure 3.3). The slope is thus small in comparison to the standard deviation of measured water levels. Moreover, the water levels increase with increasing discharge, but no additional upstream water level increase is observed that could be interpreted as a backwater effect from the curved bend, which was expected to be a bottleneck that hampers conveyance. Similar results are found for the Essche Stroom (not shown here). 


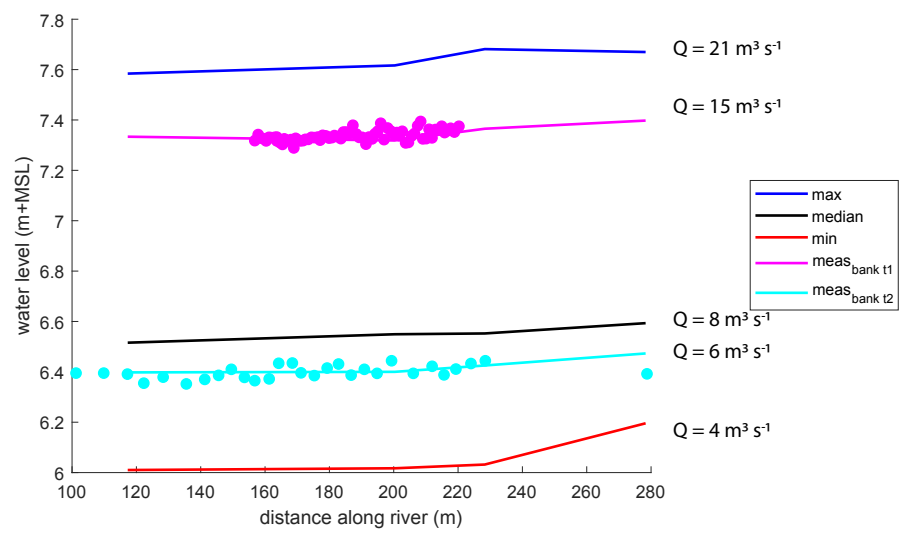

FIGURE 3.3. Longitudinal water level profiles of the Dommel River. The dots illustrate the water levels measured with the RTK-GPS at the bank and the lines the water levels continuously measured with the Keller sensors. Note that the scatter in the bank measurements is larger than the difference in the continuous water level measurements.

\section{Essche Stroom velocity measurements}

We constructed maps of the flow velocity patterns and the bathymetry for the Essche Stroom from the ADCP measuring campaigns. The depthaverage velocities are shown in top view (Figure 3.4). The velocity profile at the entrance of the bend is similar to velocity profiles in straight reaches, in which the flow is parallel to the streamwise direction and in which the highest velocities are measured in the middle of the cross-section. In the bend, the profile shows an outer bank and an inner bank recirculation cell and after the bend, the profile slowly becomes similar to a profile in a straight reach. The velocity profiles are similar for discharges of 7.2 and $8.1 \mathrm{~m}^{3} \mathrm{~s}^{-1}$ (Figure 3.4 and 3.5). The cross-section-averaged flow velocities for $7.2 \mathrm{~m}^{3} \mathrm{~s}^{-1}$ are $0.02 \mathrm{~m} \mathrm{~s}^{-1}$ smaller than for $8.1 \mathrm{~m}^{3} \mathrm{~s}^{-1}$.

Three dimensional flow patterns over the cross-section are shown in Figures 3.4 and 3.5. The streamwise flow at a discharge of $7.2 \mathrm{~m}^{3} \mathrm{~s}^{-1}$ is strong at the beginning of the scour hole. At and after the bend's apex, the magnitude of the flow is more equally spread over the cross-section, and shows secondary flow (Figure 3.4). The flow pattern at a discharge of 8.1 

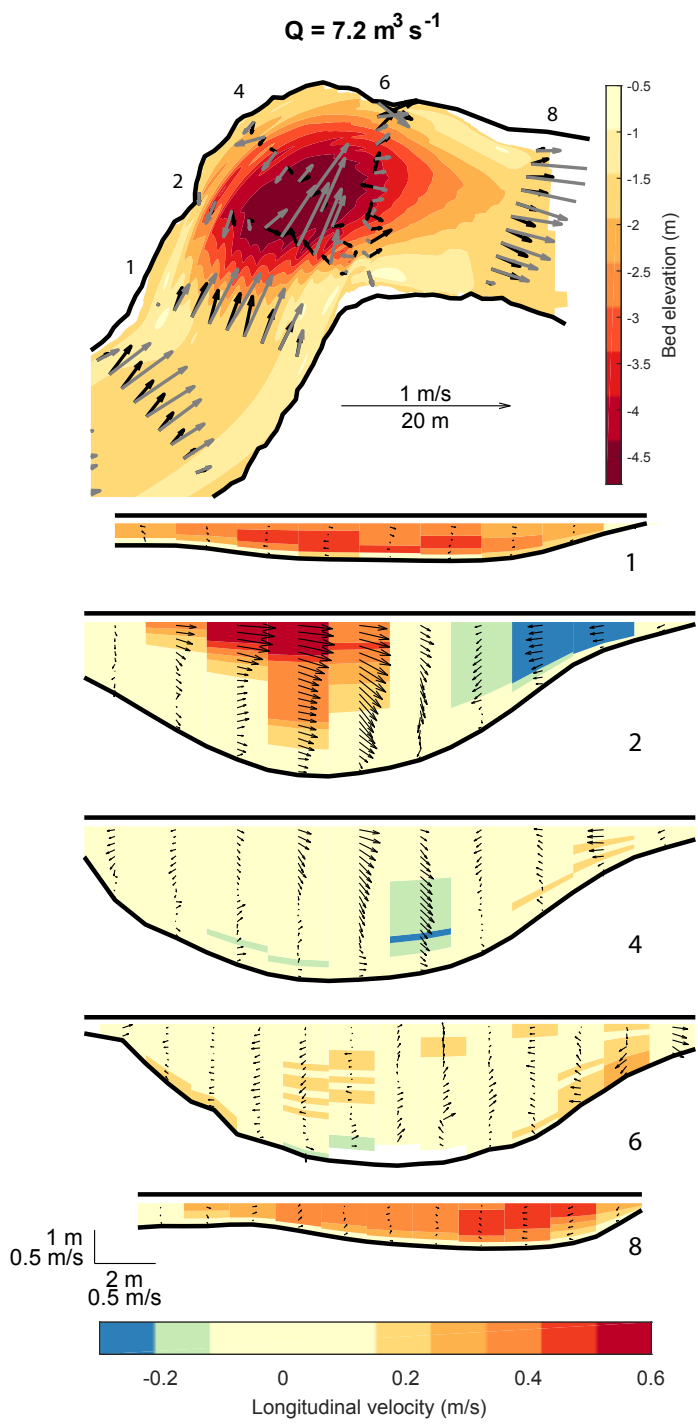

FIGURE 3.4. Measured bathymetry and depth-averaged flow velocities at the water surface and the bed in the Essche Stroom (top panel). The numbers indicate the number of the cross-section. Flow patterns of the five measured cross-sections are shown in the other panels. The inner bend is plotted at the left side and the colors indicate the streamwise flow component. The arrows depict the transverse and vertical flow components. 


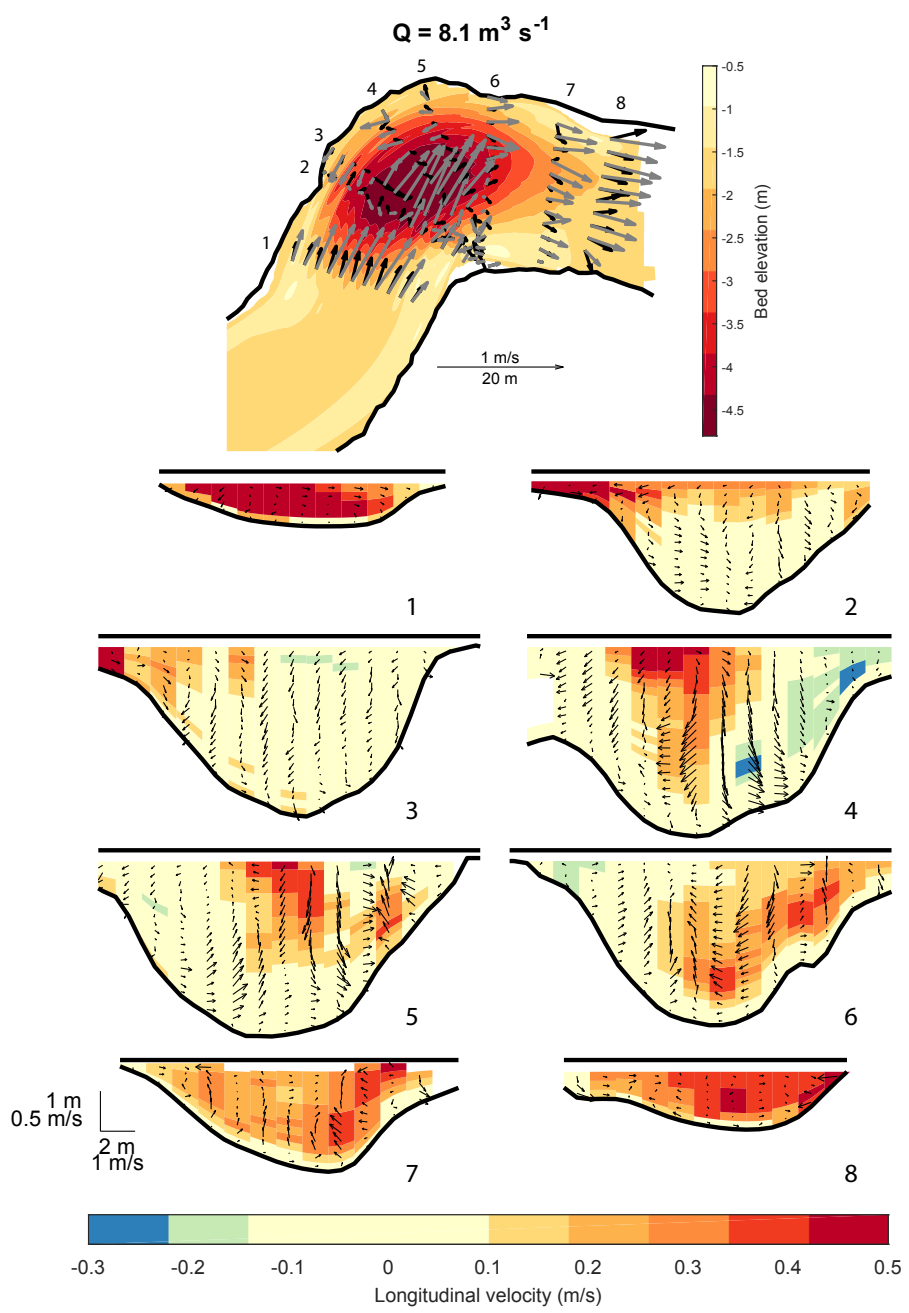

FIGURE 3.5. Measured bathymetry and depth-averaged flow velocities at the water surface and the bed in the Essche Stroom (top panel). The numbers indicate the number of the cross-section. Flow patterns of the eight measured cross-sections are shown in the other panels. The inner bend is plotted at the left side and the colors indicate the streamwise flow component. The arrows depict the transverse and vertical flow components. 
$\mathrm{m}^{3} \mathrm{~s}^{-1}$ shows that the streamwise flow concentrates right before the bend near the inner bend at the water surface, and diverts to the outer bend at the bed (Figure 3.5). This downflow is typical for sharp bends (????), but is also observed in straight bedrock canyons (?). A pronounced secondary flow is apparent similar to observations for a discharge of $7.2 \mathrm{~m}^{3} \mathrm{~s}^{-1}$. The small increase in discharge from 7.2 to $8.1 \mathrm{~m}^{3} \mathrm{~s}^{-1}$ result in a faster flow near the surface.

The PIV analysis at a discharge of $7.2 \mathrm{~m}^{3} \mathrm{~s}^{-1}$ confirms previous results. There is a clear recirculation zone in the inner and outer banks. The PIV analysis for measurements on the $2^{\text {nd }}$ of February is filmed during a much higher discharge, i.e. $16 \mathrm{~m}^{3} \mathrm{~s}^{-1}$ (Figure 3.6). The Essche Stroom was flowing overbank at several locations, but not in the bend itself. The PIV analysis shows that the horizontal flow recirculation zone decreases with increasing discharges.

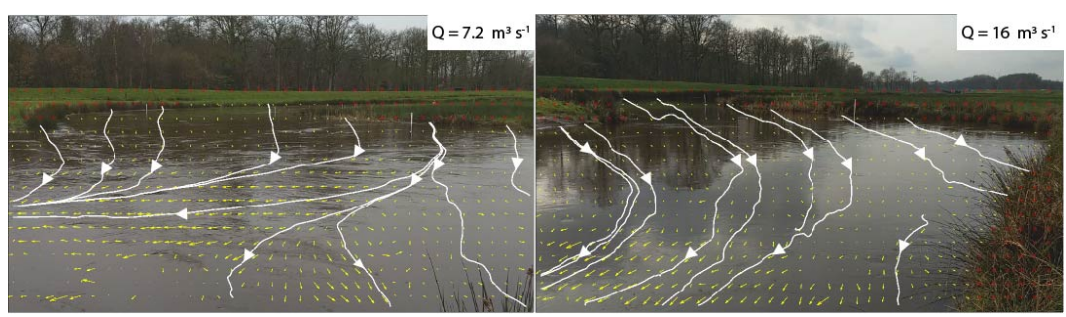

FIGURE 3.6. Surface water velocities observed based on PIV analysis for the Essche Stroom. The left panel shows the surface water velocities at a situation with a discharge of $7.2 \mathrm{~m}^{3} \mathrm{~s}^{-1}$ on January 30,2018, and the right panel the surface water velocities at a situation with a discharge of $16 \mathrm{~m}^{3} \mathrm{~s}^{-1}$ on February 2, 2018. The figure shows the recirculation cell in the outer bank, which reduces in size with increasing discharge.

\section{Dommel velocity measurements}

The bathymetry and depth-averaged velocities from the ADCP measuring campaigns in the Dommel are shown in Figure 3.7. The Dommel River shows the presences of a scour hole in the middle bend, which is similar to what is found in the Essche Stroom and many other sharp bends (?????). The depth-averaged velocity profile shows no recirculation cell in the inner bank, and only a recirculation cell in the outer bend at a discharge of $9.3 \mathrm{~m}^{3} \mathrm{~s}^{-1}$. The recirculation cell started $12 \mathrm{~m}$ downstream and ended 16 
$m$ upstream from the widest point in the river bend. The depth-averaged flow velocity showed no recirculation cell in the inner or outer bank at a discharge of $13 \mathrm{~m}^{3} \mathrm{~s}^{-1}$. The depth-averaged velocities show smaller flow velocities in the center of the bend apex, which corresponds to the location of the scour hole. A velocity profile typical of a straight reach was observed upstream of the sharp bend.

The three-dimensional flow patterns over the cross-sections are shown in Figure 3.7. The flow pattern at a discharge of $9.3 \mathrm{~m}^{3} \mathrm{~s}^{-1}$ shows a clear secondary circulation, a downward flow in middle of the bend, and an upward flow in the inner bend. In the inner bend, the flow velocities are the highest and slightly oriented to the inner bank. At the outer bank, the flow velocities are oriented upstream. The flow pattern for a discharge of 13 $\mathrm{m}^{3} \mathrm{~s}^{-1}$ distinctly differs from the flow pattern at a discharge of $9.3 \mathrm{~m}^{3} \mathrm{~s}^{-1}$, which was already shown in the top view (Figure 3.7). The flow pattern at a discharge of $13 \mathrm{~m}^{3} \mathrm{~s}^{-1}$ shows no flow reversal. The flow patterns show that the highest flow velocities are measured at smaller discharges, due to the reduction in effective cross-sectional area when a recirculation cell is present.

The PIV analyses confirm the results from the ADCP measurements (Figure 3.8). There is a clear recirculation zone at a discharge of $9.3 \mathrm{~m}^{3} \mathrm{~s}^{-1}$ and there is no recirculation zone at a discharge of $13 \mathrm{~m}^{3} \mathrm{~s}^{-1}$. During measurements of the water levels at the bank, we took a short movie of the surface water flow in the Dommel. The discharge on the $2^{\text {nd }}$ of February 2018, was $14.9 \mathrm{~m}^{3} \mathrm{~s}^{-1}$ and was thus higher than during the measuring campaign at a discharge of $13 \mathrm{~m}^{3} \mathrm{~s}^{-1}$, when no flow recirculation was observed. The PIV analysis shows that on the $2^{\text {nd }}$ of February 2018, the recirculation cell in the outer bend was present again. The recirculation zone was smaller in area than with a discharge of $9.3 \mathrm{~m}^{3} \mathrm{~s}^{-1}$, but there was a distinct flow reversal present.

\subsection{Discussion}

Bank morphology in sharp bends will impact the flow patterns and, vice versa, the flow will shape the banks. ? showed that the Dommel River creates non-erosive outer banks, which are caused by horizontal flow recirculation cells. Non-erosive banks cause the river to confine herself in her sedimentation by the formation of muddy counter-point bars (??). The formation of counter-point bars in the outer bank is visible in our cross- 

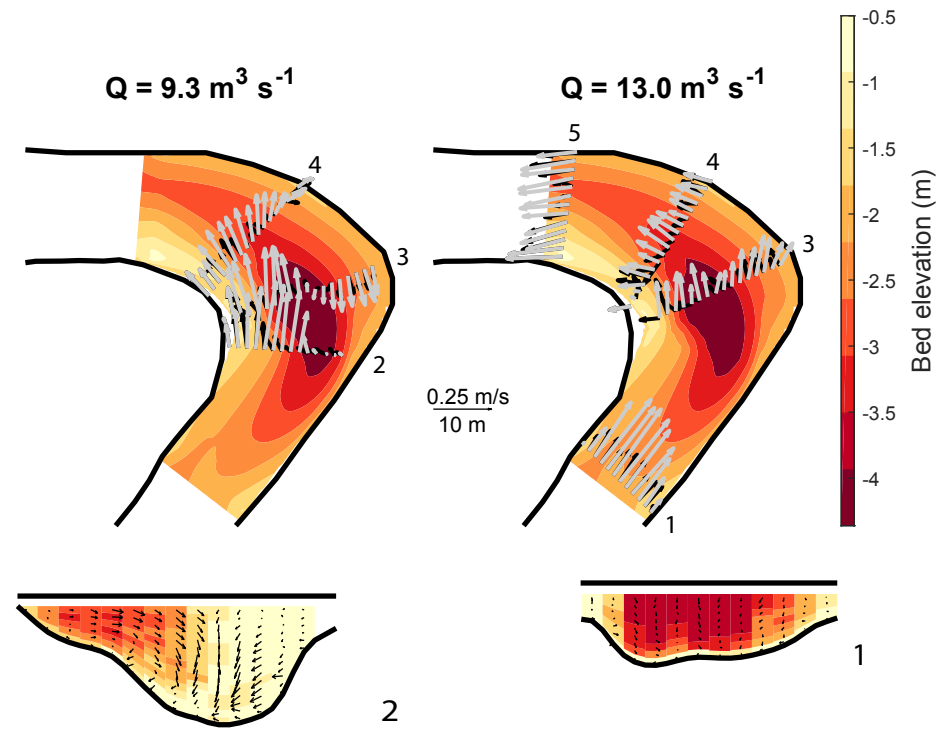

2
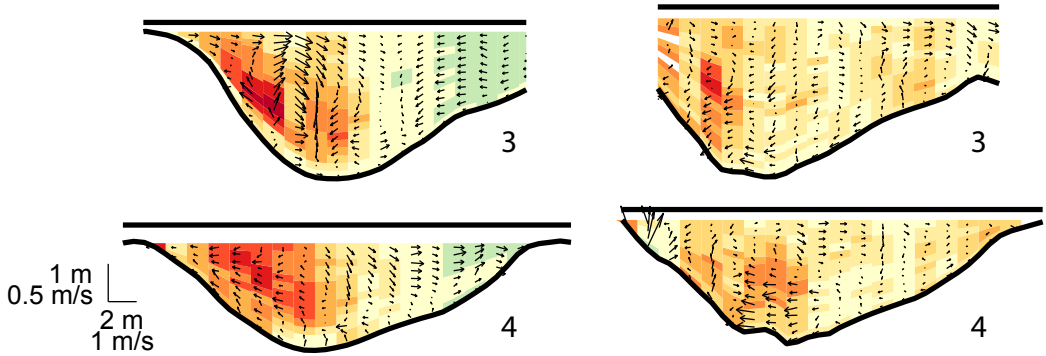

$-0.2$

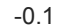

0

$\begin{array}{lcr}0.1 & 0.2 & 0.3 \\ \text { Longitudinal velocity } & (\mathrm{m} / \mathrm{s})\end{array}$

FIGURE 3.7. Measured bathymetry and depth-averaged flow velocities at the water surface and the bed in the Dommel River (top panels). The figure shows the recirculation cell in the outer bank at a discharge of $9.3 \mathrm{~m}^{3} \mathrm{~s}^{-1}$ and the absence of recirculation cells at a discharge of $13 \mathrm{~m}^{3} \mathrm{~s}^{-1}$. The numbers indicate the location of the cross-section. Flow patterns of the six measured cross-sections are shown in the other panels. The inner bend is plotted at the left side and the colors indicate the streamwise flow component. The arrows indicate the transverse and vertical flow components. 


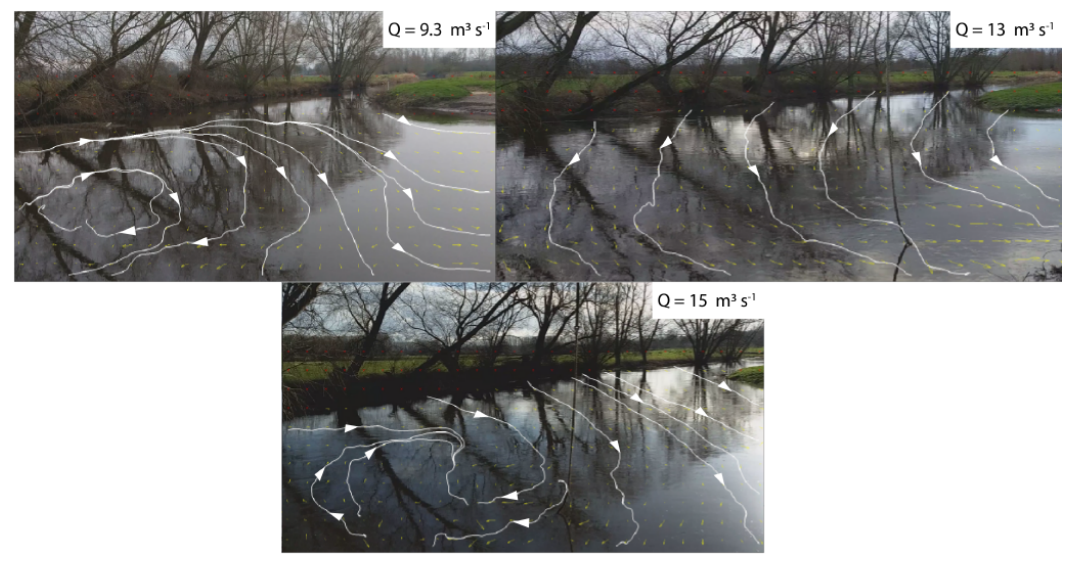

FIGURE 3.8. Surface water velocities qualitatively measured with PIV analysis for the Dommel River. The left panel shows the surface water velocities at a situation with a discharge of $9.3 \mathrm{~m}^{3} \mathrm{~s}^{-1}$ on $9^{\text {th }}$ of January, 2018, the middle panel with a discharge of $13 \mathrm{~m}^{3} \mathrm{~s}^{-1}$ on $16^{\text {th }}$ of January, 2018, and the right panel with aa discharge of $15 \mathrm{~m}^{3} \mathrm{~s}^{-1}$ on $2^{\text {nd }}$ of February, 2018.

sectional observations, where a small plateau is apparent in the bathymetry near the outer banks. Moreover, the horizontal flow recirculation in the outer bank can result in bank erosion in the inner bank (???). The Dommel River clearly shows the highest flow velocities in the inner bank, and also the Essche Stroom shows a concentration of high flow velocities at the entry of the inner bank. The Dommel River even shows the highest flow velocities for the lowest discharge conditions, which is a direct effect of the recirculation zone. This is an important finding, since bankfull discharge is often assumed to dominate morphological changes. For sharp bends, this assumption is not correct.

The results present two distinct flow patterns, one with and one without horizontal flow recirculation. The flow pattern in the Essche Stroom confirms what can be expected for sharp bends: a sharp bend develops an adverse pressure gradient that result in a recirculation cell. The flow pattern in the Essche Stroom bend is similar to the flow pattern in a sharp bend in the much larger the Mahakam River, Indonesia (?). Based on the results in the Mahakam, ? proposed a one-dimensional stationary model describing the effects of friction, curvature and cross-sectional increase (equation 11 ?). The friction and curvature representation are based on 
the findings of ?. The effect of cross-sectional increase was introduced by rewriting the one-dimensional depth-averaged momentum equation to longtitudinal water level gradient as result of cross-sectional change with distance (?). The Vermeulen model predicts the streamwise water surface gradient as in:

$$
\frac{\partial z_{s}}{\partial s}=-C_{f} F r^{2}+F r^{2} \frac{\partial}{\partial s}\left(\frac{H}{R}\right) n+\frac{F r^{2}}{W} \frac{\partial A}{\partial s},
$$

in which $z_{s}$ is the water surface elevation, $s$ is the downstream distance along the centerline, $C_{f}$ is the friction factor, $F r$ is the Froude number, $H$ is the mean depth, $R$ is the local radius of curvature, $n$ is the transverse coordinate, $W$ is the channel width and $A$ is the cross-sectional area. The first term on the right-hand side represents the roughness effect. The second term represents the transverse tilting of water surface caused by changes in curvature, which is called the curvature effect. The third term represents the water surface increase caused by the cross-sectional increase, which is called the cross-sectional effect. We apply the model to construct water surface topographies similar to what was done for the Mahakam River. We find the presence of adverse pressure gradients in both the inner and the outer bank in the Essche Stroom, which may explain the flow recirculation cells in the observations (Figure 3.9).

The results from the Dommel River provides a new insight. Although the surface topography patterns features an increasing adverse pressure gradient with discharge, flow recirculation occurs at $9.3 \mathrm{~m}^{3} \mathrm{~s}^{-1}$ and at 15 $\mathrm{m}^{3} \mathrm{~s}^{-1}$, but does not occur at $13 \mathrm{~m}^{3} \mathrm{~s}^{-1}$ (Figure 3.9). This is the first time that such evanescence and reappearance of a horizontal flow recirculation cell is described in literature. We compare the flow reduction based on the water surface gradient from the Vermeulen model with the reduction based on a local, one-dimensional depth-averaged momentum equation, retaining only the inertial term and the pressure gradient term:

$$
u \frac{\partial u}{\partial s}=-g \frac{\partial z}{\partial s},
$$

in which $u$ is the flow velocity and $g$ the gravitational acceleration. The observation at $13 \mathrm{~m}^{3} \mathrm{~s}^{-1}$ shows that the adverse pressure gradient reduces the flow velocity, more or less in accordance to the simplified momentum equation. The measured flow velocity at a discharge of $13 \mathrm{~m}^{3} \mathrm{~s}^{-1}$ reduces from 0.4 to $0.2 \mathrm{~m} \mathrm{~s}^{-1}$ over a distance of $35 \mathrm{~m}$, the average flow velocity over that distance is $0.3 \mathrm{~m} \mathrm{~s}^{-1}$. Equation 3.2 yields a water surface increase, $d z$, 

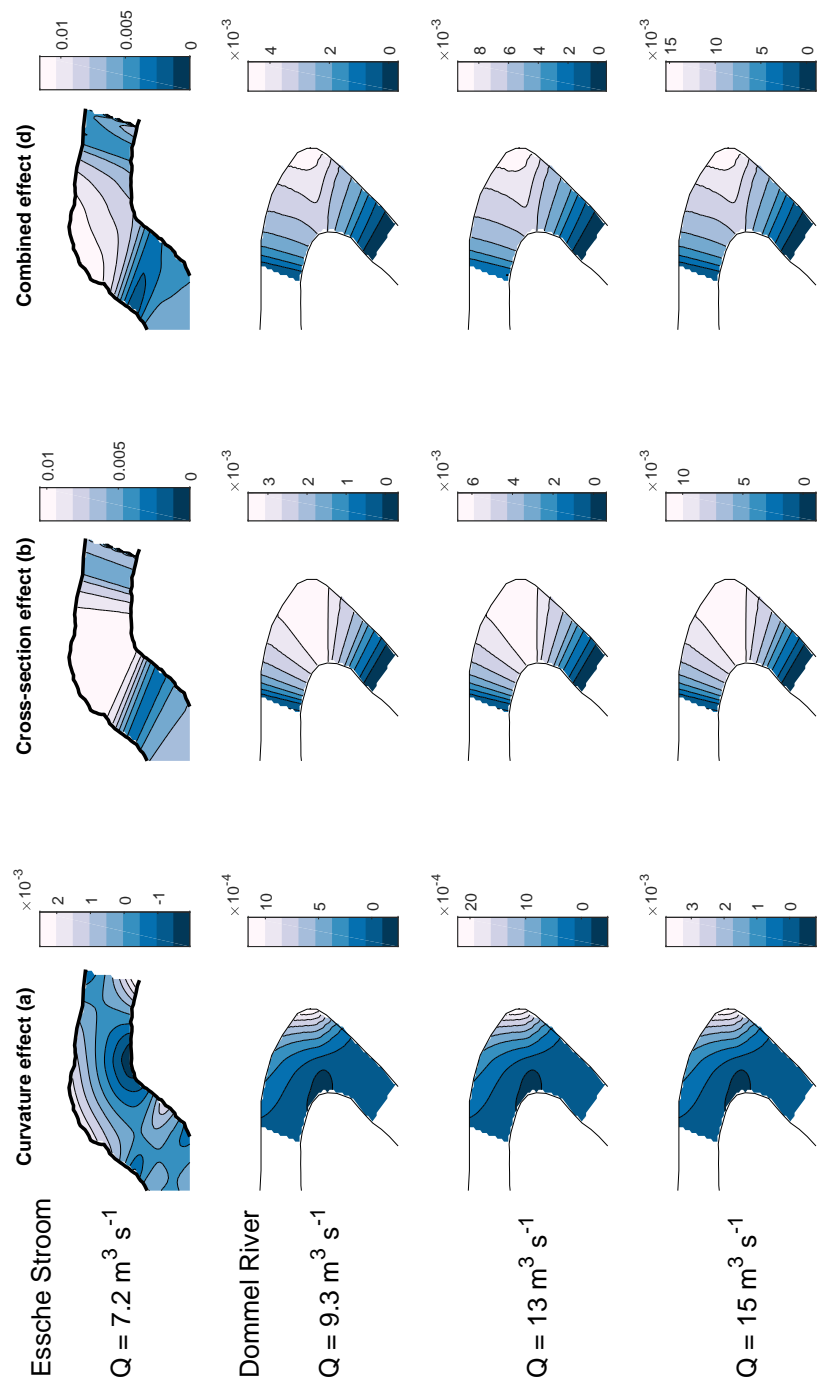

is
so
0
0
0
0

${ }^{T} \infty$
$n^{n}$
5
11
0
0

FIGURE 3.9. The adverse pressure, cross-section, water level gradient and the combined effect of these gradients for the Essche Stroom and the Dommel River with different discharges. Note that the color range per panel changes. 
of $-\frac{-0.2 \times 0.3}{9.81}=0.0061 \mathrm{~m}$, i.e. $6.1 \mathrm{~mm}$. The water level increase is even 6.8 $\mathrm{mm}$ when we use the velocity at the bend entrance. The Vermeulen model yields a comparable average water surface increase of $6.3 \mathrm{~mm}$. Such a direct comparison is impossible for the observations at 9.3 and $15 \mathrm{~m}^{3} \mathrm{~s}^{-1}$, because the local flow reduction and reversal shows not to be directly related to the surface topography predicted by the Vermeulen model. Extrapolating the velocity data to the entrance, the cross-sectional averaged flow at $9.3 \mathrm{~m}^{3} \mathrm{~s}^{-1}$ reduces roughly from 0.2 to $0.1 \mathrm{~m} \mathrm{~s}^{-1}$, which requires a water surface increase of $-\frac{-0.1 \times 0.15}{9.81}=0.0015 \mathrm{~m}$, i.e. $1.5 \mathrm{~mm}$. The Vermeulen model resulted in a water surface increase of $3.6 \mathrm{~mm}$. At $15 \mathrm{~m}^{3}$ $\mathrm{s}^{-1}$ flow velocity reduces roughly from 0.43 to $0.19 \mathrm{~m} \mathrm{~s}^{-1}$, which requires a water surface increase of $-\frac{-0.31 \times 0.24}{9.81}=0.0076 \mathrm{~m}$, i.e. $7.6 \mathrm{~mm}$. The Vermeulen model resulted in a water surface increase of $11.7 \mathrm{~mm}$. Thus, the Vermeulen model can be employed to estimate the propensity for flow recirculation to occur, but once a recirculation cell has established, the Vermeulen model is not applicable.

Qualitatively, it is possible to understand the reappearance of the recirculation cell when the discharge increases from 13 to $15 \mathrm{~m}^{3} \mathrm{~s}^{-1}$, because the adverse pressure gradient increases stronger with discharge than the flow strength at the entrance. The establishment of the recirculation cell for the smallest discharge conditions, however, is puzzling. Three potential factors to explain this: the effect of unsteady flow, lateral momentum redistribution at the entrance, and three dimensional effects. The water surface slope from unsteadiness can be calculated from the measurements and appears to be an order of magnitude smaller than the causes of water surface gradients considered in the Vermeulen model. This excludes flow unsteadiness as a possible explaining factor. The stage dependence of the lateral flow distribution at the entrance of the bend is a more likely candidate. ? and ?? showed the importance of two dimensional effects of inertia and secondary flow on the flow redistribution. These effects could create an exchange between the flow velocities in, for instance, the transverse direction. Moreover, the inflow magnitude interacts with the water surface topography. When the inflow angle changes, the surface topography will be effected, because of the flow curvature and the cross-section effect. We, unfortunately, could not test this hypothesis due to the absence of inflow measurements at $9.3 \mathrm{~m}^{3} \mathrm{~s}^{-1}$ for the Dommel River and the similar inflow angles for the Essche Stroom.

Moreover, three dimensional effects may play a role. The flow pattern in flow recirculation is intrinsically three-dimensional, in which the scour 
hole plays an important role (?????). As soon as a recirculation cell develops in the Dommel River, a mixing layer between the main flow and the recirculation cell is located above the scour hole. As the discharge increases, the main flow will occupy a larger part of the width, causing the mixing layer to shift to the outer bend and become shallower. As a result, the recirculation cell may neutralize itself, and cause the regular flow pattern at 13 $\mathrm{m}^{3} \mathrm{~s}^{-1}$ to re-establish. The Vermeulen model can then be applied across the entire channel. As the discharge increases further, the water depth will increase, and the adverse pressure gradient will increase so strongly that the recirculation cell will recover. More research is needed to validate this hypothetic interpretation based on, for example, model simulations or continuous monitoring of the state changes in the Dommel River.

\subsection{Conclusions}

Horizontal flow recirculation is frequently observed in sharp river bends. This study shows that horizontal flow recirculation can be a transient phenomenon. Observations were taken in two small rivers: the Essche Stroom and the Dommel Rivers. The observations in the Essche Stroom reveal a similar flow pattern as previously observed in a much larger river, which result from an adverse water level gradient that develops because of flow curvature and cross-sectional area increase. In both the inner and the outer bend, the flow reverses. In the Dommel bend, the flow reverses in the outer bend during low flow. With increasing discharge, the flow reversal vanishes, and then reappears during the highest flow conditions. Especially the appearance of the recirculation cell during low discharge is surprising, and cannot easily be explained from the main mechanisms held responsible for flow reversal to date. Also, unsteadiness of the flow cannot explain the transient character of the recirculation cell. We identify two potential explanatory factors: the transverse flow distribution at the entrance of the bend, and three-dimensional effects related to scours holes. Additional research is recommended to either reproduce or continuously monitor the state changes in the flow dynamics of the Dommel River. 



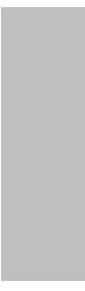



4

\section{Regional groundwater response to instantaneous lowering of river water levels}

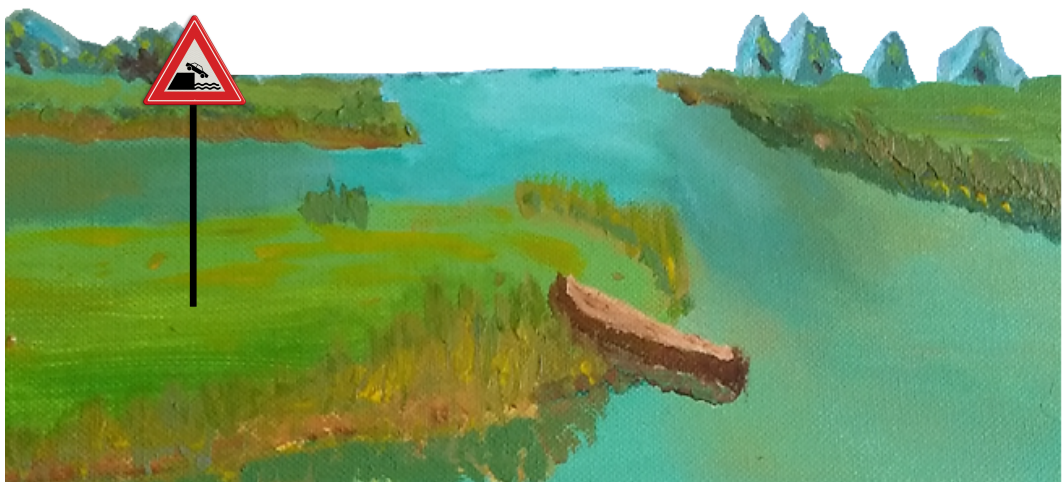

This chapter is based on: Geertsema, T. J., A. J. Teuling, L. A. Melsen, V. F. Bense, A. J. F. Hoitink, W. J. ZaAdnoordijk, And R. Uijlenhoet, Shipping incident provides unique opportunity to infer hydraulic properties on regional river-groundwater exchange. 


\section{Abstract}

On the evening of December $29^{\text {th }}, 2016$, a loaded motor tanker sailed through a weir complex in the Meuse River in the Netherlands. After the incident, the weir was broken and caused the Meuse water level to decrease by $1.7 \mathrm{~m}$ in approximately 12 hours and by $2.8 \mathrm{~m}$ in 3 days over $27.5 \mathrm{~km}$, which is the distance of the reach from the broken weir to the next upstream weir. The river water drop impacted the groundwater levels on either side of the river with a decline up to $0.5 \mathrm{~m}$ within a day and up to one kilometer from the river. This event provided the unique opportunity to study the regional rivergroundwater exchange, as if it were a large-scale groundwater pumping test along a line segment. We compared this event with results from actual pumping tests with a representative scale of a few kilometers. In the comparison, we focus on saturated hydraulic conductivity and specific yield derived from the pumping tests and estimated from the described river lowering. Hydraulic conductivity is a key soil parameter in Earth sciences and engineering. However, the effective hydraulic conductivity as well as the effective specific yield vary in space. This study aims to investigate to what extent the spatial variations between effective saturated hydraulic conductivity and effective specific yield for the local pumping tests and the regional effects of lowering of the river can be understood. With an analytical one-dimensional Boussinesq solution, we investigated a range of possible hydraulic conductivities and specific yields using measurements during the Meuse River lowering. The range of possible hydraulic conductivities and specific yields reduced using both the measured surface water levels and discharges. The effective hydraulic conductivity derived from the pumping test data was found to be similar to that derived from the river lowering. The effective specific yields, on the other hand, were almost twice as small for the pumping tests compared to the river lowering. This means that a larger fraction of the aquifer is released from storage during the river lowering, while the flow through the medium is almost stable. This study thus shows that models and predictions should consider the spatial variation of the effective specific yield. Moreover, future research should investigate the causes and effects of varying effective specific yield along varying spatial scales. 


\subsection{Introduction}

On the evening of December $29^{\text {th }}, 2016$, a thick fog was blocking the sight of the captain of a loaded motor tanker sailing on the River Meuse near the town of Grave, the Netherlands. The captain failed to see the lock complex ahead and rammed into the weir at Grave (Figure 4.1). The ship broke through the frame of the weir and plunged down about three meters through the resulting hole. The incident did not result in casualties or environmental pollution (?, in Dutch). However, the broken weir caused a sudden water outflow between the broken weir of Grave and the upstream weir of Sambeek (Figure 4.1), a $27.5 \mathrm{~km}$ long segment of the river, and connected water bodies. Meanwhile, water managers in the area closed the Maas-Waal Canal between Mook and Nijmegen and lowered the upstream weir of Sambeek by $28 \mathrm{~cm}$ (Figure 4.1). The water managers in addition started a short term fix of the weir. After a couple of failed attempts, a dam structure was successfully built in the river on January $23^{\text {rd }}, 2017$, which restored the river water levels to normal values. This was fortunate because the River Meuse is an important economic waterway, being the second largest river in the Netherlands, with an annual average discharge of $350 \mathrm{~m}^{3} \mathrm{~s}^{-1}$. The sudden lowering of the surface water levels in the Meuse also led to a subsequent lowering of groundwater levels on either side of the river. This provided a unique opportunity to study river-groundwater interaction on a regional scale.

The exchange between regional groundwater systems and large rivers is an important hydrological process, but notoriously hard to quantify. The effective hydraulic conductivity is the main parameter controlling the exchange between groundwater and river systems and is subject to a scaling issue (e.g. ?????). Measurements at one spatial scale cannot easily be translated to other scales, because different processes dominate at different scales (?????). Most river-groundwater studies concentrate on small rivers with relatively small water level variations affecting groundwater flow up to distances of only tens to hundreds of meters from the river (e.g. ???) or on the extraction of groundwater near a river (e.g. ???). Saturated hydraulic conductivity is typically estimated using pump or slug tests yielding values that are representative for at most a few kilometers. The interest in groundwater flow, however, is often at catchment or river reach scales of a couple of kilometers to hundreds of kilometers, a scale at which the effective hydraulic conductivity can vary over a range of several orders of magnitude as a result of spatial heterogeneity. The evidence for increas- 
ing effective hydraulic conductivity with increasing scale is overwhelming and has been shown over a variety of scales, methods and fluid flows (?). ? found an increase of effective hydraulic conductivity by a factor 1000 for the Pierre Shale derived from core tests and a regional mass balance. ? found an increase of almost 2 orders magnitude for a granite block derived from a pulse test $(10 \mathrm{~cm})$ versus model calibration of cross-hole tests $(100$ $\mathrm{m})$. ? additionally showed an increase of several orders of magnitude from laboratory to regional scales for different sites. The cause and even the existence of such scale effects remain controversial, but the most widely accepted reason is the better connectivity between highly conductive zones as compared to lower conductive zones (??). The controversy of the scaling effect is probably the reason why most studies on river-groundwater interaction are conducted at small scales, while the interest for water management and long-term pollution investigations is prominent at catchment or large river reach scales.

In addition to hydraulic conductivity, specific yield also plays an important role in groundwater response to instantaneous river lowering. The specific yield controls the release from storage as result of changes in head. This parameter is often even more uncertain than the hydraulic conductivity (????). The specific yield is often taken from literature or measured simultaneously with the hydraulic conductivity. When the specific yield is unknown or not correctly measured, it is estimated in two ways: (1) by assuming a certain specific yield for an entire area (?) or (2) by calibrating and validating river-groundwater exchange models using inverse techniques (????). Studies using a value from literature assimilate the potential error of the effective specific yield in the output variable and use the specific yield as spatial constant. Most studies, however, calibrate the specific yield, which makes it very sensitive to the employed (conceptual) model and its uncertainties, errors and input parameters. Moreover, these models are typically not calibrated for an extreme event such as described above. Most of these studies are neglecting the interaction between specific yield and hydraulic conductivity and its effects on the output (??). ? state that most research is concentrated on hydraulic conductivity rather than on the relevance of specific yield. An effective specific yield is therefore used, which is also subject to scaling effects (?). Although it is unknown how this effective parameter behaves at different spatial scales, especially for scales larger than a few kilometers.

The Meuse case provides a unique opportunity to study regional rivergroundwater exchange as a result of sudden river lowering. This setting 
can be seen as a large-scale incidental pumping test along a line, because a large volume of water is extracted from the area and we study the resulting drawdown cone. The advantage of such opportunistic research is that underrepresented phenomena can be studied in a setting that would otherwise not occur (e.g. ?????). On the other hand, opportunistic research does not involve designing an experiment and we therefore had to work with routine observations. This study aims to infer regional-scale values for effective hydraulic conductivity and effective specific yield using information contained in the hydrological groundwater response to the weir failure, and to compare those values to previous estimates from pumping tests. We considered the effective hydraulic conductivity as a representation of the one-dimensional groundwater flow through the medium and the effective specific yield as a representation of the one-dimensional change in groundwater table as result of change in head. We used a 1D groundwater model based on a solution to the Boussinesq equation, which is run for a range of hydraulic conductivities and specific yields. Eventually, we constrained hydraulic conductivities and specific yields based on the observed groundwater heads and discharge dynamics, and compared those to values obtained from pumping tests. This unique event thus provided an opportunity to study regional river-groundwater interaction, which will ultimately allow us to improve our models and predictions of groundwater flow at the regional scale.

\subsection{Data and study area}

Multiple routine observations are available to analyse the situation before, during and after the event. We used the soil parameters measured from pumping tests reported by the Geological Survay of the Netherlands, TNO (??????, in Dutch). The pumping test reports describe an unconfined aquifer consisting of sand with thin unconnected gravel and clayey layers. The average measured base level is 35 meter below the surface, with a standard deviation of 19 meter over the whole aquifer. Figure 4.1 shows the measured hydraulic conductivity values in the vicinity of the river, varying from 47 to $100 \mathrm{~m} \mathrm{~d}^{-1}$. The aquifer's hydraulic conductivities vary between 53 and $118 \mathrm{~m} \mathrm{~d}^{-1}$ in the same aquifer but outside the map. Two pumping tests deteremined a specific yield of 0.2 and one yielded a value of 0.25 . In addition, we studied the rainfall amounts, river water levels, river discharge and groundwater levels during the event. Hourly rainfall was mea- 


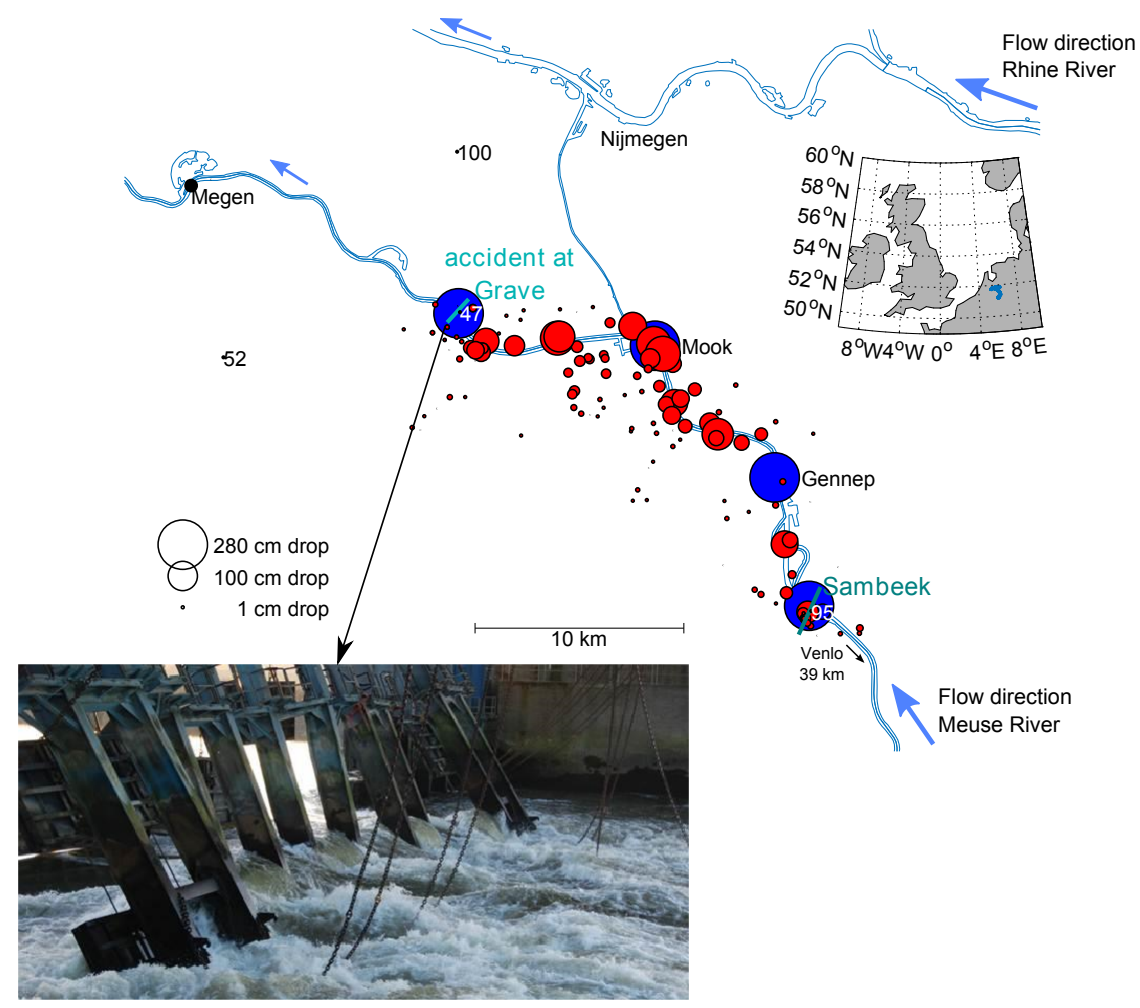

FIGURE 4.1. Map of the water level drop three days after the incident, when the water level reached its minimum. The blue dots illustrate the river water level drop and the red dots the groundwater table drop. The numbers refer to measured hydraulic conductivities in $\mathrm{m} \mathrm{d}^{-1}$ from pumping tests. Image courtesy of Rijkswaterstaat.

sured at the meteorological station Volkel, which is the closest automatic weather station. River water levels and discharges were measured with a 10-minute frequency (Rijkswaterstaat; https://waterinfo.rws.nl/, last access: 5 September 2019). Groundwater levels were measured with a daily frequency (DINOloket; https://www.dinoloket.nl/ondergrondgegevens, last access: 5

September 2019). We selected all measurements located within $4 \mathrm{~km}$ from the affected Meuse River section. To ease the comparison, all data were 
aggregated to an interval of one day.

Below we give an overview of the changes in river water levels, rainfall, river discharge and groundwater levels during the event. Immediately after the incident, the river water level dropped with $1.7 \mathrm{~m}$ in 11 hours and 40 minutes (Figure 4.2a). After this, a small flood peak propagated through the river, which slowed down the drop. Eventually the river water level dropped to $2.8 \mathrm{~m}$ below the normal level in 3 days. On January $13^{\text {th }}$, the river water level rose due to a rain fall event. On January $23^{\text {rd }}$, the river water levels returned to its initial level due to the fixed dam structure. There was no substantial rain in the research area until the $13^{\text {th }}$ of January (Figure $4.2 \mathrm{~b}$ ). We ignored the influence of the rain event by concentrating on the first 15 days after the incident. The river discharge downstream differed from that upstream due to storage change in the segment between the weirs of Grave and Sambeek (Figure 4.2b). The storage change in the segment can be subdivided into surface water release of the river and the connecting bodies and ground water release. This is described in the water balance:

$$
\frac{\Delta S_{g w}}{\Delta t}=-Q_{\text {in }}+Q_{\text {out }}-\left(\frac{\Delta S_{\text {riv }}}{\Delta t}+\frac{\Delta S_{\text {can }}}{\Delta t}+\frac{\Delta S_{\text {lak }}}{\Delta t}\right),
$$

in which $Q_{i n}$ and $Q_{\text {out }}$ are, respectively, the upstream and downstream river discharge. The difference between the upstream and downstream river discharge is defined as the total release over the described segment ( $\frac{\Delta S_{\text {tot }}}{\Delta t}$ in Figure 4.2c, green line). $\frac{\Delta S_{r i v}}{\Delta t}$ is the surface water release of the river, $\frac{\Delta S_{\text {can }}}{\Delta t}$ is the surface water release of the Meuse-Waal Canal, $\frac{\Delta S_{\text {lak }}}{\Delta t}$ is the surface water release of the connected lakes. The surface water release of the river, canal and lakes together is called the surface water release $\left(\frac{\Delta S_{s w}}{\Delta t}\right)$. The surface water release of the river was determined by the volume change in time, which was calculated by the cross-sectional area change as result of the river water level drop in time, times the river length (Figure 4.2c, blue line). The cross-sectional areas were based on the dredged cross-sectional areas at Mook, Grave, Gennep and Sambeek (?, in Dutch). In addition, the surface water release of the Maas-Waal Canal and of two small lakes, Mookerplas and Plaesplas, contributed to the surface water release by $1.47 \cdot 10^{6}$ and $1.07 \cdot 10^{6} \mathrm{~m}^{3} \mathrm{~d}^{-1}$ in the first day and $1.17 \cdot 10^{6}$ $\mathrm{m}^{3} \mathrm{~d}^{-1}$ over 3 days, respectively. These values were based on reported water level drops in time (?, in Dutch) and the deduced areas from satellite images. $\frac{\Delta S_{g w}}{\Delta t}$ is the groundwater release as a result of groundwater table lowering determined by the difference between total release and sur- 


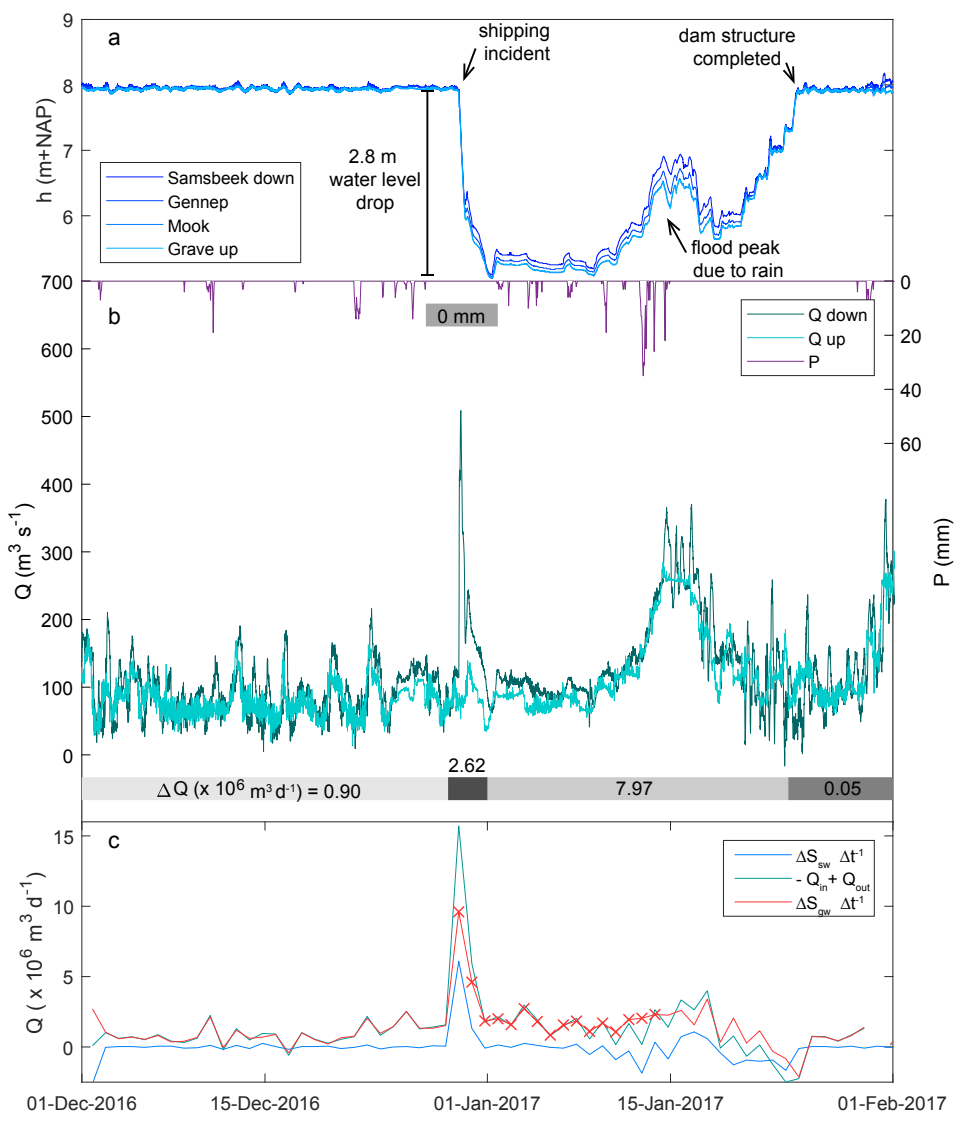

FIGURE 4.2. Water level and discharge measurements during the accidental lowering of the River Meuse. The upper panel (a) illustrates the measured river water levels for the stations in the segment between the weir of Grave and Sambeek. In the middle panel (b), the Meuse river discharges for the measurement location upstream of the segment, in Venlo (Q up), are compared to those for the measurement location downstream of the segment, in Megen ( $Q$ down). The panel also includes the rainfall time series $(\mathrm{P})$. The gray bars indicate the average storage change of the segment per day during four periods. Note that the average storage change discharged per day within three days from the incident is three times the value during the month before the incident. The lower panel (c) illustrates the difference between downstream and upstream measurements, the total release $\left(\frac{\Delta S_{t o t}}{\Delta t}\right)$, subdivided into surface water release $\left(\frac{\Delta S_{s w}}{\Delta t}\right)$ and groundwater release $\left(\frac{\Delta S_{g w}}{\Delta t}\right)$. 
face water release (Figure 4.2c, red line). The groundwater release is called groundwater outflow in the remainder of this chapter.

The magnitude of groundwater drawdown had a distinct relation with the distance from the river (Figure 4.3). Close to the river, $28 \mathrm{~m}$ from the river bank, the water table drop was about $1.5 \mathrm{~m}$ in 3 days, while $1 \mathrm{~km}$ from the river hardly any response was observed (Figure 4.1). Groundwater reacts both in space and in time. Figure 4.3 shows that the response is most pronounced during the first three days, after which the response weakens. The speed of the groundwater table drop stabilizes approximately within 4 days to a drop of 5 to $8 \mathrm{~cm}$ per day for the considered distances. Distance from the river is, however, not the only explanatory factor for the observed groundwater table response. The response can vary substantially at one distance, for example close to $100 \mathrm{~m}$ distance (Figure 4.3). This can be explained by heterogeneity in hydraulic conductivity and specific yield. The distribution of saturated hydraulic conductivities and specific yields of the measurements could differ from the actual distribution in the study area because of preferential measurement locations (?). To reduce this effect, we averaged the groundwater table drop over locations at similar distances from the river (Figure 4.3).

\subsection{Groundwater model}

Since analytical solutions are often found to be similar to numerical solutions (e.g ????) and since numerical solutions are rarely applied to sudden surface water drawdown studies, we will compare the described measurements with a one-dimensional analytical solution to the Boussinesq equation specifically derived for a surface water drawdown case. Analytical solutions to the Boussinesq equation are based on the following assumptions (?):

- only horizontal groundwater flow is assumed and resistance to vertical flow is neglected (the Dupuit-Forchheimer assumption),

- there is no input or output of groundwater other than discharge to the river,

- the release of water from storage is instantaneous with water level change,

- the aquifer is homogeneous and isotropic, 


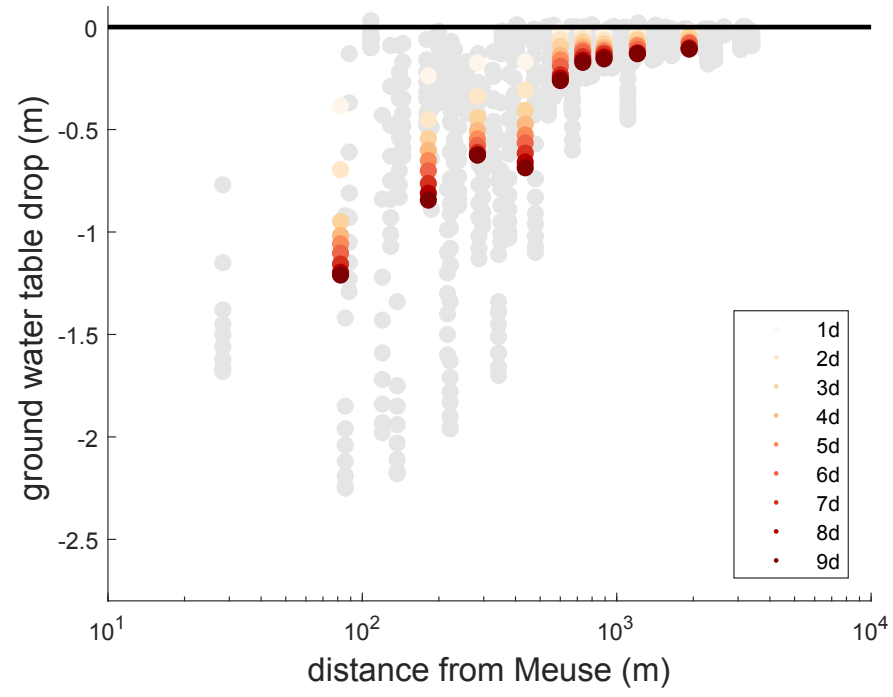

FIGURE 4.3. Space-time dependence of the groundwater table drop for the first 9 days after the incident. The coloured points indicate the spatially averaged groundwater table drop, which are used for comparison with the Boussinesq equation. The darker the color the more days have passed since the incident. The gray points are the measured groundwater table drops. The black line indicates the initial groundwater table.

- the aquifer bottom is horizontal,

- the capillary fringe is negligible.

The validity of the fourth assumption is dependent on spatial scale and therefore indirectly tested in this study. These assumptions result in the following one-dimensional Boussinesq equation:

$$
\frac{\partial h}{\partial t}=\frac{K}{S} \frac{\partial}{\partial x}\left(h \frac{\partial h}{\partial x}\right),
$$

with the following boundary and initial conditions for a semi-infinite aquifer:

$$
\begin{gathered}
h(0, t)=h_{1}, \\
h(\infty, t)=h_{0}, \\
h(x, 0)=h_{0} .
\end{gathered}
$$


Here, $h$ is the groundwater head with respect to the aquifer base (m), $h_{0}$ is the initial groundwater head and the head at infinite distance from the river $(\mathrm{m})$ and $h_{1}$ the groundwater head at the river immediately after the incident $(\mathrm{m})$. Since the aquifer height is $10 \mathrm{~m}+\mathrm{MSL}$ close to the river, the initial river water level was $8 \mathrm{~m}+\mathrm{MSL}$, the aquifer depth was $35 \mathrm{~m}$ and the total surface water drop was $2.8 \mathrm{~m}$, we used $h_{0}$ of $33 \mathrm{~m}$ (depth of 35-10+8) and $h_{1}$ of $30.2 \mathrm{~m}$ (depth of $35-10+8-2.8$ ). $x$ is the distance from the river (m) and $t$ is the elapsed time starting from the shipping incident (d). $K$ is the saturated hydraulic conductivity $\left(\mathrm{m} \mathrm{d}^{-1}\right), S$ is the specific yield (-) and $K / S$ is the hydraulic diffusivity $\left(\mathrm{m} \mathrm{d}^{-1}\right)$.

We used an implicit iteration approach presented by?, which was found to perform much better than the linear solutions. The non-linear onedimensional analytical solution of the groundwater head is then given by:

$$
\tilde{h}^{2}=h_{1}^{2}+\left(h_{0}^{2}-h_{1}^{2}\right) \operatorname{erf}\left(\frac{\xi}{\sqrt{4 \tilde{h}}}\right),
$$

in which erf() is the error function and

$$
\xi=\frac{x}{\sqrt{\frac{K}{S} t}} .
$$

For the discharge from aquifer to river, the solution is given for $x=0$ by ?:

$$
Q=-\frac{2 L \Gamma K}{\sqrt{\frac{K t \tilde{h}}{S}}} \times \frac{1}{\left(2 \tilde{h}+\frac{x \Gamma}{2 \tilde{h} \sqrt{\frac{K t \tilde{h}}{S}}}\right)},
$$

in which $L$ is the river reach length (m) of 27,530 $\mathrm{m}$ in our case and

$$
\Gamma=\frac{1}{\sqrt{\pi}}\left(h_{0}^{2}-h_{1}^{2}\right) \exp \left(-\frac{\xi^{2}}{4 \tilde{h}}\right) .
$$

We used a range of hydraulic conductivities and specific yields to investigate the best combination of and the interaction between these two parameters. The range for the hydraulic conductivity was log-normally scaled from 1 to $1000 \mathrm{~m} \mathrm{~d}^{-1}$. The range for specific yield was normally scaled from 0.02 to 0.4 . We validated the results of Eq. 4.3 with the measured groundwater tables and those of Eq. 4.5 with the groundwater release using the Kling-Gupta efficiency (?) as a measure for the goodness of fit. Finally, we combined the Kling-Gupta efficiencies for groundwater head and groundwater release by averaging their individual Kling-Gupta 
efficiencies. Using the combined results, we assessed the distribution of the hydraulic conductivities and specific yields for the pumping test and the river lowering.

\subsection{Results}

The Kling-Gupta efficiencies corresponding to the parameter distributions resulting from the Boussinesq model are shown in Figure 4.4. The groundwater levels and the groundwater outflow are quite insensitive for specific yield in contrast to the saturated hydraulic conductivity. For groundwater levels, the Boussinesq model performs best for hydraulic conductivities between 15 and $40 \mathrm{~m} \mathrm{~d}^{-1}$ at specific yields between 0.3 and 0.4 . For specific yields between 0 and 0.1 , the hydraulic conductivity performs best from 3.5 to $7 \mathrm{~m} \mathrm{~d}^{-1}$ (Figure 4.4a). For the groundwater outflow, the Boussinesq model performs best for hydraulic conductivities between 85 and 250 $\mathrm{m} \mathrm{d}^{-1}$ at specific yields between 0.3 and 0.4 . For specific yields between 0 and 0.1 , the hydraulic conductivity performs best from 500 up to more than $1000 \mathrm{~m} \mathrm{~d}^{-1}$ (Figure 4.4b). Figure 4.4 (panels a and b) show that the optimal values of hydraulic conductivity and specific yield are strongly related, albeit differently for groundwater levels than for groundwater outflow. For the combination of groundwater level and outflow, the model performance is still insensitive to specific yield, but the range decreases to specific yields smaller than 0.2 (Figure 4.4c). The model performs best for hydraulic conductivity values between 30 and $60 \mathrm{~m} \mathrm{~d}^{-1}$. These values are comparable to the hydraulic conductivity values of 5 to $100 \mathrm{~m} \mathrm{~d}^{-1}$ in the area with a standard deviation of 5 to $10 \mathrm{~m} \mathrm{~d}^{-1}$ used in the current operational groundwater model for the Netherlands, REGIS II (?). Figure $4.4 \mathrm{~d}$ shows the distributions of the Kling-Gupta efficiencies above zero, both for the pumping test measurements and for the Boussinesq model. Bivariate normal distributions are fitted to the log-hydraulic conductivities and the specific yields. The optimal hydraulic conductivity values are 42 and 72 $\mathrm{m} \mathrm{d}^{-1}$ for the Boussinesq model and for the pumping test measurements, respectively. This difference is within the standard deviations of the methods. We therefore consider the hydraulic conductivities similar for both methods. The optimal specific yield is two times larger for the Boussinesq model than for the pumping test measurements. 

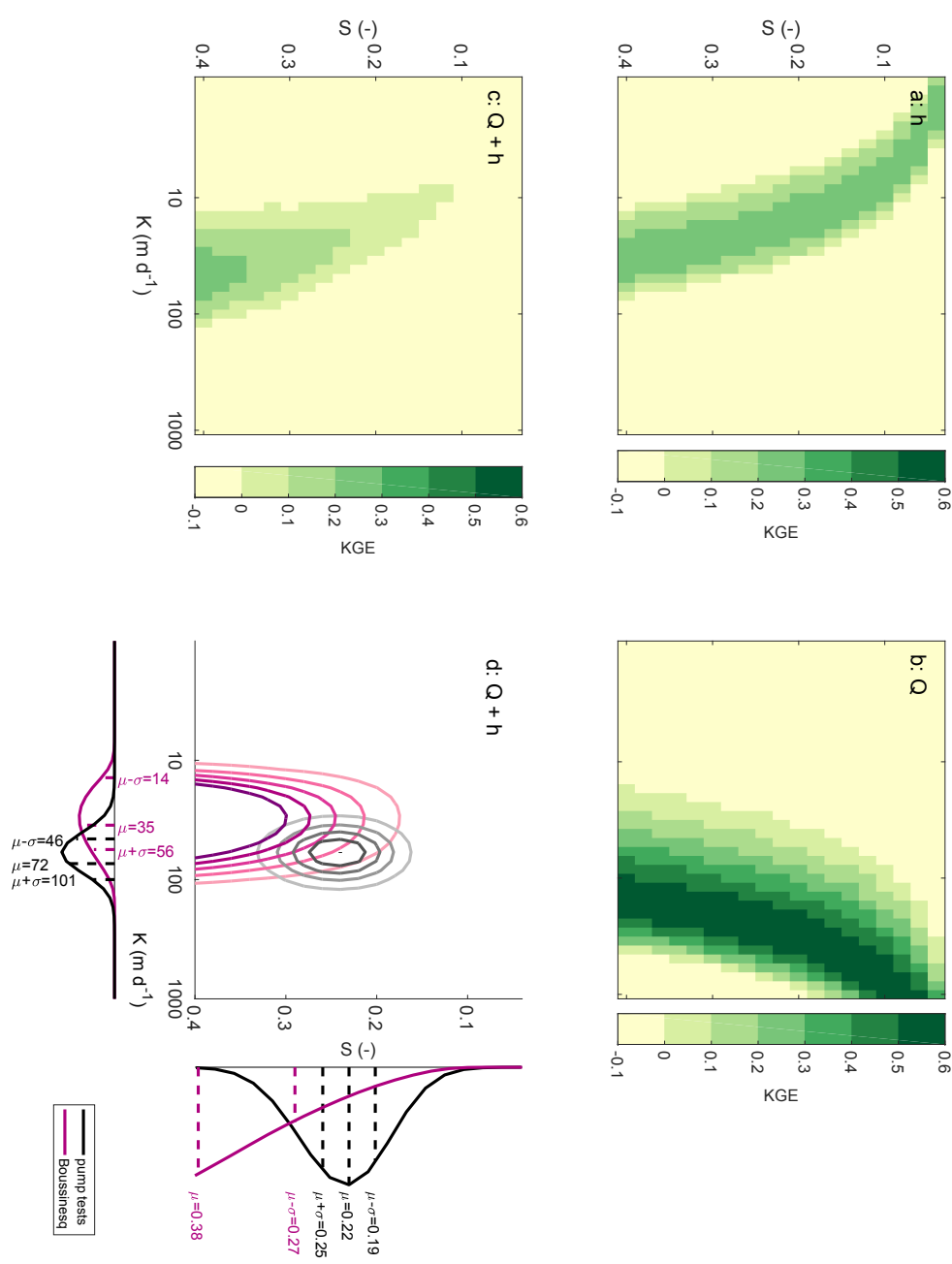

FIGURE 4.4. Response surfaces of the parameters of the Boussinesq model, using hydraulic conductivities $(K)$ ranging from 1 to $1000 \mathrm{~m} \mathrm{~d}^{-1}$ and specific yields $(S)$ ranging from 0.02 to 0.4 . The colors indicate the values of the Kling-Gupta efficiency (KGE) and the different panels represent the KGE for groundwater levels (a), for groundwater outflow (b) and the combination of the groundwater level and the river discharge (c). Panel d represents the distributions of the hydraulic conductivity and specific yield for the pumping test measurements (black) and the Boussinesq model (purple), where $\mu$ indicates the mean and $\sigma$ the standard deviation 


\subsection{Discussion}

Although both the pumping test measurements and the Boussinesq model are physics-based, reality is approximated in both cases because of measurement errors, missing processes, and/or assumptions. The pumping test method, for example, yields different hydraulic conductivity values than other methods, such as slug tests or texture analysis. We therefore used all available measurements in the study area to account for measurement errors. As far as the Boussinesq equation is concerned, it does not involve a resistance layer at the river bed, although this is an important characteristic according to river-groundwater interaction studies (??). There are no bed resistance measurements available, however, and it is unknown how the riverbed resistance changes with scale (??). We did not use the riverbed resistance in the analysis to prevent introducing extra uncertainty with an unknown and unmeasured parameter. Moreover, it is expected that large rivers have lower bed resistances, because they transport larger sediments and have a smaller clogging potential. Further research is necessary to incorporate the riverbed resistance in the Boussinesq model and to investigate the theory regarding scale issues for river beds. In addition, not all assumptions required for the Boussinesq model are defendable. The river does, for instance, not fully penetrate the aquifer. The DupuitForchheimer assumption is therefore strictly speaking not valid, although vertical groundwater flow near the river will not affect groundwater flow significantly for larger distances from the river (???). Since the Boussinesq model is compared with groundwater levels 87 meters from the river, we assume that the violation of the Dupuit-Forchheimer assumption does not affect the results. The aquifer is not homogeneous and isotropic and the flow is not one-dimensional either. The effective parameters incorporate the effects of preferential flow paths possibly caused by river bends or former geological stream beds. We investigate in this study how different scales affect our parameter estimates only indirectly. The other assumptions are considered valid for this study area. We eventually conclude that the Boussinesq model can be used in our study area after careful consideration of the (correct) assumptions.

The range of hydraulic conductivities that lead to better model performance differs substantially for groundwater level and groundwater outflow (Figure 4.4a and b). The best performing hydraulic conductivities, when comparing modeled and measured groundwater levels, are 5 to 6 times smaller than the values based on groundwater outflow. Introducing 
bed resistance or another aquifer depth will not reduce the difference in optimal values, however, this will affect the best performing hydraulic conductivities for both the groundwater outflows and the water levels. Combining the results for groundwater level and groundwater outflow yields a more precise and sensitive outcome (??). The hydraulic conductivity derived in this manner is very similar to the values from the pumping tests and the values employed in the operational model, REGIS II. We did not find a substantial scale effect for the hydraulic conductivity. This can have two reasons: (1) the scales of the river lowering and the pumping tests are too much alike or (2) scale effects in this unconfined sandy aquifer are small.

Combining groundwater levels and discharges does not only constrain the range of hydraulic conductivities, but also the range in specific yields. The combined results are, however, still less sensitive to the value of the specific yield. The optimal value of the specific yield derived from the Boussinesq model is almost twice as large as that from the pumping tests. According to ? and ? this could be caused by better connectivity between highly porous areas instead of low porosity areas in the aquifer (????). While previous work showed that the hydraulic conductivity increases with increasing spatial scales (???), our study shows that the specific yield increases with increasing spatial scale and that the hydraulic conductivity remains similar for different spatial scales. This result is also found by? at local scales. It can thus be concluded that a larger portion of the water in this aquifer is released from the storage per unit head difference for the reported river lowering than for the employed pumping tests. More research is needed to investigate causes and effects of these findings for different scales, but it is apparent that models and predictions should consider varying the effective specific yield along spatial scales.

Water availability in highly-regulated river systems can permanently be increased when groundwater can be lowered to store rainfall within the time frame of nowcasting. The first step is to understand the groundwater table rise per unit rainfall. Figure 4.5 shows that the groundwater table barely reacts under 'normal' conditions. However, when the river level and groundwater table are lowered abruptly, the groundwater table can rise 5 to 10 times more vigorously to rainfall than under 'normal' conditions. More rainfall can thus be retained in the subsurface when groundwater tables are low. Consequently, less groundwater will be flowing into the rivers, resulting in lower river water levels and discharges. To apply this strategy in reality, more research is needed to understand the effects of 
river-groundwater exchange, such as impact on ecology, soil compaction and erosion.

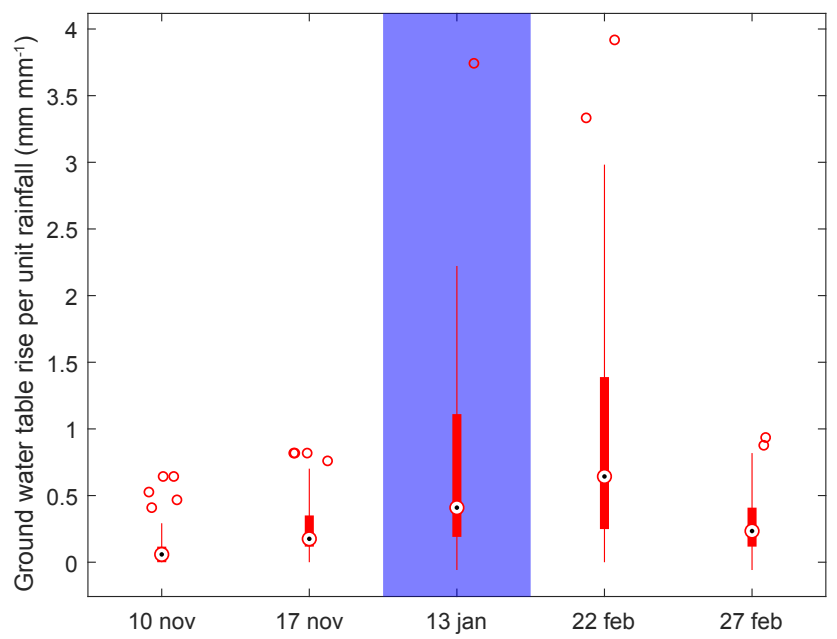

FIGURE 4.5. Groundwater table rise per $\mathrm{mm}$ rainfall. Blue area indicates the period of low river water levels. Box plots show the median (black dot), the $25^{\text {th }}$ and the $75^{t h}$ percentiles (red bar with larger width) and the range of groundwater table rise (entire bar) with a few outliers (red dots). Note that the groundwater table rise is larger during and right after the lowering of the river water levels.

\subsection{Conclusions}

In this study, we investigated a sudden lowering of the surface water level by $2.8 \mathrm{~m}$ in the Meuse River affecting a river reach of $27.5 \mathrm{~km}$ and its surroundings. The effective hydraulic conductivity and specific yield were estimated using an analytical Boussinesq solution and these soil parameters were compared with results of local pumping tests. Both the pumping test measurements and the Boussinesq model provided a range of hydraulic conductivities and specific yields. For the Boussinesq model, the range of hydraulic conductivities and specific yields became smaller when using both the water level and the discharge measurements to constrain the parameters. Using both observations therefore reduces the uncertainty in the estimates of these soil hydraulic properties. The range of hydraulic conductivity values was similar for the pumping tests and the river low- 
ering. The range of specific yield values was substantially smaller for the pumping tests than for the river lowering. This indicates that a larger proportion of groundwater storage is released for the river lowering. The largest studied spatial scale, the regional river reach scale, is thus predominantly affected by increasing specific yield and not by increasing hydraulic conductivity. The interaction between hydraulic conductivity and specific yield is thus crucial to understand river-groundwater flow interaction. Future research should concentrate on understanding the causes and effects of these findings for different spatial scales. 
CHAPTER

5

\section{Simultaneous occurrence of} flood peaks at a lowland confluence

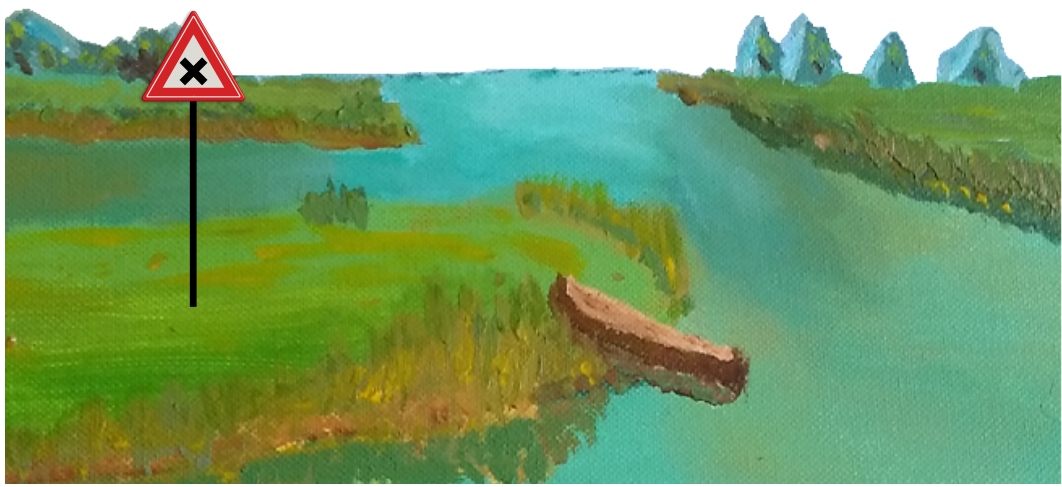

This chapter is based on: T.J. Geertsema, A.J. Teuling, R. Uijlenhoet, P.J.J.F. Torfs \& A.J.F. HoITINK, Anatomy of simultaneous occurrence of flood peaks at a lowland confluence, Hydrol. Earth Syst. Sci., 22, 5599-5613, https://doi.org/10.5194/hess-22-5599-2018, 2018 


\begin{abstract}
Lowlands are vulnerable to flooding due to their mild topography in often densely populated areas with high social and economic value. Moreover, multiple physical processes coincide in lowland areas, such as those involved in river-sea interactions and in merging rivers at confluences. Simultaneous occurrence of such processes can result in amplifying or attenuating effects on water levels. Our aim is to understand the mechanisms behind simultaneous occurrence of discharge waves in a river and its lowland tributaries. Here, we introduce a new way of analyzing lowland discharge and water level dynamics, by tracing individual flood waves based on dynamic time warping. We take the confluence of the Meuse river, $\sim 33,000 \mathrm{~km}^{2}$, with the joining tributaries of the Dommel and Aa rivers as an example, especially because the January 1995 flood at this confluence was the result of the simultaneous occurrence of discharge peaks in the main stream and the tributaries and because independent observations of water levels and discharge are available for a longer period. The analysis shows that the exact timing of the arrival of discharge peaks is of little relevance, because of the long duration of the average discharge wave compared to typical time lags between peaks. The discharge waves last on average 9 days, whereas the lag time between discharge peaks in the main river and the tributaries is typically 3 days. This results in backwater effect that can rise up to $1.5 \mathrm{~m}$ over a distance of $4 \mathrm{~km}$ from the confluence. Thus, local measures to reduce the impact of flooding around the confluence should account for the long duration of flood peaks in the main system.
\end{abstract}

\title{
5.1 Introduction
}

In January 1995, water was only a few centimetres below the crest of the dikes in the lowlands of the major rivers Rhine and Meuse. This high water event created fears for major flooding across large parts of the Netherlands, causing the Dutch government to decide to evacuate more than 200,000 inhabitants from the area immediately under threat. Luckily these fears did not materialise and people could return to their homes within a few days. However, this high water event did lead to local flooding (Figure 5.1). The flood occurred just upstream of the city center of 's Hertogenbosch, where two tributaries (Dommel and Aa) join, and spread over a small region. This small region included an economically important European highway and could have spread over a much larger area if the du- 


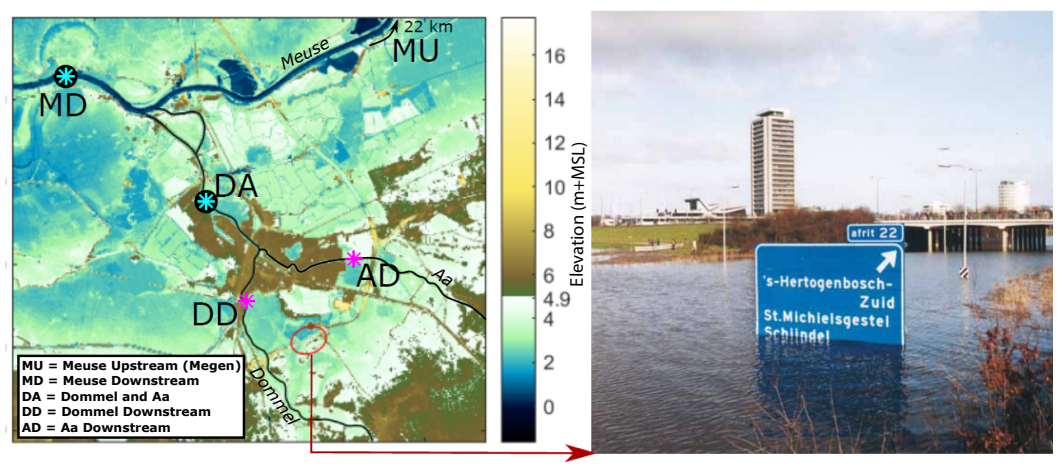

FIGURE 5.1. Flood proneness near the confluence of the Meuse and the tributaries Dommel and Aa. Left panel: DEM of the area around the Dutch city of 's Hertogenbosch is shown. The green and blue colors indicate areas below $4.9 \mathrm{~m}$ above MSL (the maximum water level in the Meuse that was reached in January 1995 and also the maximum protected flood level). These areas are, at least potentially, prone to flooding. The magenta asterisks indicate gauge stations with discharge and water level data and the cyan asterisks indicate stations with only water level data. The red circle indicates the flooded area of the European highway E25 (right panel; ?).

ration of the overtopping would have been longer (Figure 5.1). The overtopping was the result of water levels rising to $4.9 \mathrm{~m}$ above mean sea level (msl) in the Dommel, indicated by the water authorities as maximum protection level. It was concluded that the simultaneous occurrence of the discharge peaks in the Meuse river and the Dommel tributary likely caused the flooding, but no in-depth analysis of the simultaneous occurrence has been performed so far.

While simultaneous occurrence (coincidence) of high discharge and storm surge has been investigated (???), only few studies have addressed the processes leading to simultaneous occurrence of discharge peaks. In one of these studies, ? analyzed the sensitivity of changing hydrological response to the relative timing and succession of discharge peaks by subwatersheds, to investigate the possibility of reducing flood risk. The cause of the relative timing and succession, however, was not considered in their analysis, making it difficult to extrapolate their findings. A key point from their analysis was that flood impacts are unpredictable when synergy occurs between two sub-watersheds. In another study by ?, it is shown that a discharge wave accelerates with river training, resulting in simultane- 
ous occurrence of flood peaks in the Rhine river and the Neckar tributary, which partly causes increasing Rhine flood discharges. ? analysed the simultaneous occurrence of discharge peaks of the Rhine and Neckar based on trend analysis, without offering details of individual discharge events. While in rain-fed systems, the variability in the hydrograph shapes of individual peak discharge events can be so large, that changes in the relative timing cannot readily be translated to a change in flood risk.

Various factors contribute to the process of simultaneous occurrence of discharge peaks at lowland confluences. These include spatial precipitation distribution, precipitation duration, length of the drainage network, the slope of the catchment area and the antecedent soil moisture. The spatial-temporal variability of precipitation is a key factor in the simultaneous occurrence of discharge peaks. Since there are no discharge peaks to coincide if there is no rain in one of the catchment areas. The spatial precipitation pattern over a larger river basin and the lowland tributary might show little correlation (?). Precipitation events exceeding 1 day can cover more than $10^{4} \mathrm{~km}^{2}$ (????) and may therefore be comparable for a part of the river basin, but not for the entire basin of medium-sized rivers (river lengths between 300 and $1000 \mathrm{~km}$ ). On the other hand, the climatological precipitation maxima can be influenced by orographic effects and can therefore be relatively close to the lowland area, which after all lead to a correlated spatial precipitation distribution between both catchments. Even if the precipitation pattern would be homogeneous in both catchment areas, then the shorter drainage network length of the lowland tributary should result in discharge peaks reaching the confluence before the peak in the main river (??). In addition to the factors spatial precipitation pattern and drainage network length, the process of simultaneous occurrence at confluence is influenced by duration of the discharge peaks (?). The multiple lowland tributaries can increase the duration of the discharge peaks due to the different arrival times at the main river and can therefore result in simultaneous occurrence of the discharge peaks, as has been reported for large river basins such as the Amazons (?). This leads to the question what the dominant factors are at medium-sized rivers and whether the event described above reflects a general pattern of possible simultaneous occurrence of flood peaks or simply is a rare extreme event.

This study aims to increase our understanding of simultaneous occurrence of flood peaks at confluences in lowland areas, by investigating the precipitation, discharge and water level dynamics for peak discharge events in the lower branch of the River Meuse. We will address the follow- 
ing research questions:

- Under which conditions do discharge peaks coincide at the selected lowland confluences?

- How are water level profiles in lowland tributaries affected by backwater effects associated with simultaneous occurrence of a flood peaks in the main river?

Peak discharge hydrographs vary in time due to heterogeneity in precipitation patterns and antecedent catchment characteristics. A single flood event may be insufficiently representative to gain generic insight into the conditions when discharge peaks coincide and what the consequences are. Here we carry out an analysis of a selection of events leading to the highest discharges, and establish the impacts on water levels. The precipitation patterns for these events provide insight in the variety of conditions that may lead to simultaneous occurrence of discharge peaks, whereas water level analysis offers insight into the possible consequences. Obviously, extreme water levels in tributaries can lead to inundation of larger areas when the surrounding region is flat (i.e. in lowlands).

The lowland Dommel and Meuse confluence is used as study area for two reasons. First, because simultaneous occurrence reportedly occurred in January 1995. Second, the study area is uniquely suited for this research since routine and independent observations of water height and discharge are available at several locations in the Meuse and its tributaries. The nine highest discharge events of the Meuse between 1999 and 2015 are analyzed in detail, to gain insight in the spatio-temporal precipitation and discharge patterns. For these events, the time lags between peaks in the Meuse and the Dommel and Aa are determined, as the timing indicates the potential of simultaneous occurrence of discharge peaks. We employ a method that is relatively new in hydrology to calculate time lags, dynamic time warping (DTW), which is introduced in Section 5.2 (Methods and Materials). The Meuse river basin, its tributaries and the employed discharge and precipitation data are described in more detail in the same section. Section 5.3 (Results) shows the precipitation patterns prior to these discharge events, and the resulting time lags between the Meuse and the tributaries Dommel and Aa for the studied discharge peaks. In addition, the effects of simultaneous occurrence of discharge peaks on water levels in the rivers are analyzed. Finally, we will discuss our results and conclude that the exact timing of the discharge peaks is not the single and most important factor 
in explaining the hydrological consequences of the simultaneous occurrence of discharge peaks at lowland confluences (Section 5.4, Discussion, and Section 5.5, Conclusions).

\subsection{Methods and materials}

\section{Dynamic Time Warping}

Dynamic time warping (DTW) is a relatively new method and has so far seen few applications in the field of hydrology (??). The DTW method compares time series to determine, for example, the time shift or the similarity between these time series. Within hydrology, the DTW method can have great value to determine transports through the system, for example of substances or water quantities (?). The method can therefore be used to compare transport effects through and between catchment areas, for example rainfall-runoff characteristics or distribution of pollutions. This comparison can be performed for one discharge event or for multiple years. We have used the DTW method to determine the time lag between rainfall and runoff, and the time lag between the nine highest discharge peaks of the different catchments, namely of the Meuse and the Dommel and Aa. The advantage of DTW is that no assumptions are needed regarding the definition of a wave in discharge time series. This is in contrast to common methods based on the centre of mass and the unit hydrograph. The only required input data are the discharge time series and a possible restriction of the warping path. We have used one week before and after the discharge peak as input signal. Considering discharge wave propagation, the time lags between stations cannot be infinite. Therefore, warping paths greater than one week are not used, but this warping path restriction can be increased for larger catchments. Moreover, the method has no difficulty with different diffusion effects of the discharge time series and DTW is unique in considering the time axis elastic / dynamic, which is desirable to match similar shapes in different phases, such as long wave propagation. ? and ? provide a detailed description of the DTW method. Below, we describe step-by-step the essence of the method using two discharge time series as an example (Figure 5.2a), $x_{i}$ (upstream) with $i=1 . . n$ and $y_{j}$ (downstream) with $j=1 . . m$.

- Step 1: Standardisation 

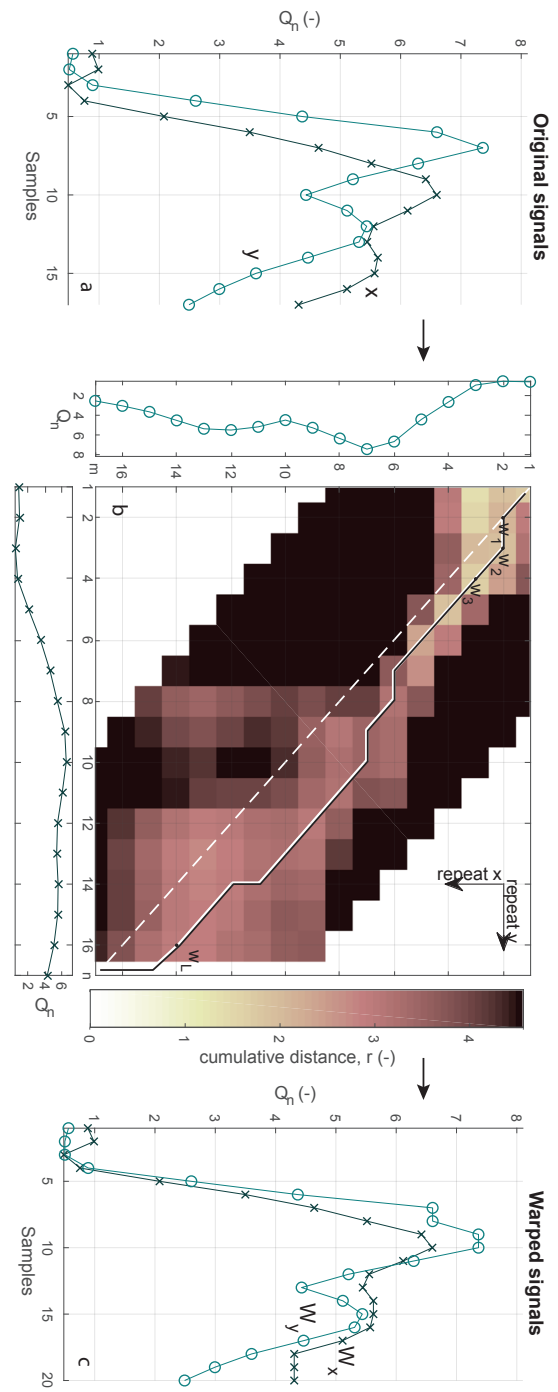

FIGURE 5.2. Principle of Dynamic Time Warping. The original time series (a) were used for the cumulative distance matrix (b), which shows the cumulative distance between points in the time series on the $x$-axis and $y$-axis. The black line shows the warping path and the white dashed line shows the path without time lag. The difference between the black and the white dashed line is the visualized time lag. The warping path was used to construct the warping signals (c). 
For optimal matching of the time series, the amplitudes of $x$ and $y$ should be similar, which is achieved by standardizing both time series (through subtracting the mean and dividing by the standard deviation). This operation changes the hydrographs in terms of scale, but not in terms of shape and is similar to common methods such as cluster analysis. It is also used in other hydrological studies employing DTW (??). A property of standardization is that the euclidean distances between two standardized time series can become equally spaced in periods without peaks, which makes the method unsuitable for DTW in these circumstances. This was prevented by limiting the analysis to the nine highest discharge peaks. The Derivative Dynamic Time Warping (DDTW) method can provide a solution to the need of standardization (?), but the minor tidal influence at the lowland confluence makes DDTW not applicable in this case.

- Step 2: Euclidean and cumulative distance

The Euclidean distance, $d\left(x_{i}, y_{j}\right)$, between the two time series is expressed as an $n$-by- $m$ matrix,

$$
d\left(x_{i}, y_{j}\right)=\left|x_{i}-y_{j}\right|,
$$

which should not be confused with the physical distance between the two stations. The distance is used to find optimal matches by minimizing the distances. The cumulative distance, $r(i, j)$, is the sum of the distance $d(i, j)$ of the current element and the minimum of the cumulative distances of the surrounding elements:

$$
r(i, j)=d\left(x_{i}, y_{j}\right)+\min \left\{r_{i-1, j-1} ; r_{i-1, j} ; r_{i, j-1}\right\} .
$$

Figure $5.2 \mathrm{~b}$ shows the $x$ and $y$ time series below and to the left of the figure with the cumulative distance. The cumulative distance is shown using colors, with the lighter colors showing a smaller cumulative distances and the darker colors a larger cumulative distances between the samples of the time series. The figure also shows that the cumulative distance increases to the end of the time series, which results from the summation of the (cumulative) distance from the smallest horizontal left, vertical up or diagonal upperleft element (right hand-side of the equation Equation 5.2) In the next step, we will further explain the path of the cumulative distance. The white spaces in the figure correspond to the warping path restriction of one week. 
- Step 3: Warping path

The warping path, $W$, is a matrix that maps $x$ to $y$ with the lowest cumulative distance (black line in Figure 5.2b) and basically reconstructs the $i^{\prime} s$ and $j^{\prime} s$ of the right hand-side of the plus in Equation 5.2 (black line in Figure 5.2b). The warping path in Figure 5.2b connects thus the path with the lightest colours. The length of the path is not necessarily equal to the length of $x$ or $y$ due to the dynamic time lags, where $i$ is not equal to $j$ (horizontal and vertical movement of the warping path in Figure 5.2b). Hence,

$$
\begin{aligned}
& W_{x}=w_{1}, w_{2}, \ldots, w_{l}, \ldots, w_{L}, \\
& W_{y}=w_{1}, w_{2}, \ldots, w_{l}, \ldots, w_{L},
\end{aligned}
$$

where $W_{x}$ and $W_{y}$ are the $x^{\prime} s$ and $y^{\prime} s$, respectively, of the lowest cumulative distances with lengths, $L$, of $\max (m, n) \leq L<m+n$. In the given example $n$ and $m$ have 17 samples and $L$ has 20 (Figure 5.2a and Figure 5.2c). The warping path is subject to the following constraints related to the dependency on the cumulative distance:

1. Boundary conditions: requires the warping path to start in the top left and end in the bottom right of the matrix (Figure 5.2b);

2. Continuity: restricts the allowable step size not to be greater than 1 relative to the previous $i$ and $j$, thus moving horizontally, vertically or diagonally with steps of 1 (Figure 5.2b);

3. Monotonicity: forces the points in $W$ not to go back in time (black line is only going down and/or to the left Figure 5.2b).

The boundary conditions constrain requires a start-up time before a 'stable' time lag is found. We used a start-up time equal to the warping path limitation, thus one week. The example in Figure 5.2b shows a start-up time of one day therefore $w_{1}$ and $w_{L}$ are connected to the 2nd and the 16th sample, respectively. The final result of the warping path into a time series is shown in Figure 5.2c. Note that the time series before and after warping are not equal. The $W_{x}$ and $W_{y}$ are not used for further analysis, because of the lack of physical interpretation of the time series after the warping proces, instead the 
indices to transform $x$ and $y$ into $W_{x}$ and $W_{y}$ are used in the further analysis.

- Step 4: Time lag and duration of discharge peaks

The difference between indices to transform $x$ and $y$ into $W_{x}$ and $W_{y}$ was not constant during the analyzed discharge wave, for example due to diffusion. When a diffusive discharge wave is compared with a non-diffusive discharge wave, the slope of the rising and falling limbs differ between the two waves. This difference results in a variation of the time lag along the rising and falling limbs of the discharge waves, regardless of the time lag influenced by advection. The time lag was calculated as the modal difference between the indices to transform $x$ and $y$ into $W_{x}$ and $W_{y}$, as the modal difference is not influenced by diffusion. Figure $5.2 \mathrm{~b}$ shows the time lag by the model of (diagonal) difference between the white dashed and the warping path. The time lag at $w_{1}$ is zero, at $w_{2}$ one and at $w_{L}$ two, but the model time lag from $w_{1}$ and $w_{L}$ is two days.

The duration of the discharge peaks was defined as the time the discharge is above the $5 \%$ highest discharges over the fifteen analyzed years.

\section{Study area and data}

\section{River Meuse}

The Meuse drains an area of $33,000 \mathrm{~km}^{2}$ between northern France and the Netherlands (Figure 5.3) and experiences a temperate climate. The Meuse is mainly rain-fed and has an average annual discharge of $350 \mathrm{~m}^{3} \mathrm{~s}^{-1}$. The rain-fed flow regime is erratic and the catchment has different geological and orographic settings, causing different response times and precipitation patterns within the Meuse catchment area (???). The Meuse can be divided into three parts: Meuse Lorraine, Ardennes Meuse and the lowland Meuse (see ?). Meuse Lorraine has mild valley slopes and lies between two ridges. It therefore responds temperately to precipitation, which is partly retained in reservoirs. The Ardennes Meuse consists mainly of hard rock, has steep valley slopes, and as such responds flashy, besides some retention in reservoirs. The lowland Meuse has very mild slopes and lies in deep alluvial deposits and therefore responds slowly to precipitation. The 
largest amount of precipitation falls in the Ardennes and therefore contributes most to the discharge (??).

\section{Tributaries Dommel and Aa}

The Dommel and Aa catchments represent $5 \%$ of the Meuse catchment and flow from the Belgian Kempen region to the Dutch city of 's Hertogenbosch (Figure 5.3). The average discharges of the Dommel and the Aa are $14 \mathrm{~m}^{3} \mathrm{~s}^{-1}$ and $8 \mathrm{~m}^{3} \mathrm{~s}^{-1}$, respectively, and their gradients are $\sim 75 \mathrm{~m}$ per $100 \mathrm{~km}$. The Dommel and Aa are rain-fed and, due to the high groundwater levels, have a flashy character despite the river's deep alluvial basins. The Aa has been straightened and canalized in the past hundred years. The Dommel has mostly kept its natural plan form. Downstream of the confluence of the Dommel and Aa, the river is called Dieze. When the water level in the Dieze is less than 5 centimetres higher than the Meuse, the weir in the Dieze is closed and the water discharges through the Drongelse Canal, which has a capacity of $100 \mathrm{~m}^{3} \mathrm{~s}^{-1}$. The aim of the river training is to prevent the Meuse from flooding areas in the Dommel and Aa catchments. Retention areas of 8.60 million $\mathrm{m}^{3}$ are used when the discharge capacity of the Drongelse Canal is not sufficient in discharging the Dommel and Aa when the weir to the Meuse is closed. The weir in the Dieze was closed only for a few hours in the focus period 1999-2015, namely during the January 2011 event.

\section{Discharge and precipitation data}

In this study, we used hourly measured water levels and discharges of the Meuse at Megen (MU) and of the Dommel (DD) and Aa (AD) between 1999 and 2015 (Figure 5.1). Flow velocities were measured every 15 minutes using a current meter, FLOW 2000 measuring device. The flow velocities were converted to discharges using a known cross-sectional area. The water level differences were computed by subtracting MD from MU, and DA from $\mathrm{DD}$ or $\mathrm{AD}$ (Figure 5.1). The water levels in this area are controlled by weirs and dikes due to the high flood risk, but the position of the gauging stations were chosen such that the water levels would be least influenced by the weirs.

In addition to discharge and water level data, a data set of daily precipitation for Europe was used (?). The data set interpolates the European precipitation observations (using the European Climate Assessment 


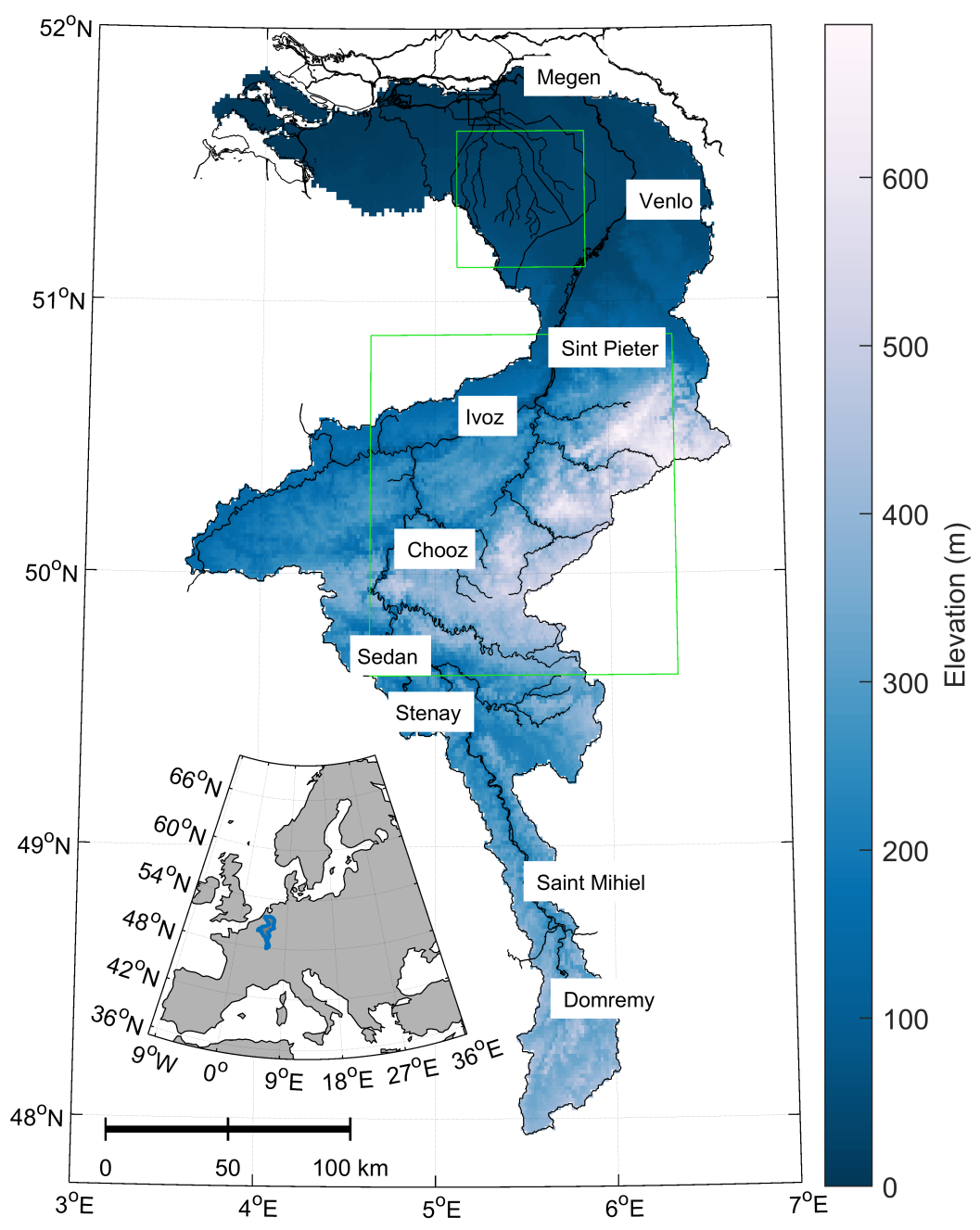

FIGURE 5.3. Map of the Meuse, Dommel and Aa catchments. The locations of the main gauging stations in the Meuse are shown. Color indicates elevation, and green boxes indicate the areas over which the precipitation is assumed representative for the Meuse and Dommel/Aa catchments, respectively. The white box indicates the area of Figure 5.1 


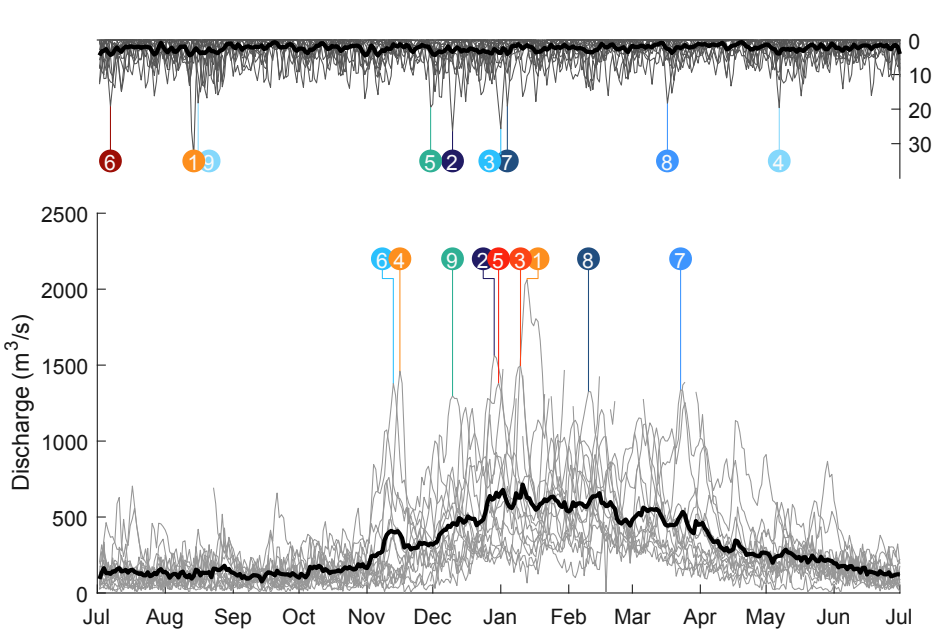

FIGURE 5.4. Precipitation and discharge extremes for the Meuse. The grey lines show measurements and the black line shows the average value over the measuring period. The colors of the peaks indicate the year and the numbers the decreasing order of the maximum discharges. Note the strong seasonality in discharge, with peaks only occurring in the period November-March, whereas precipitation events occur year-round.

Data set; https://www.ecad.eu/, last access: 24 October 2018) on a grid of $0.25^{\circ}$ latitude by $0.25^{\circ}$ longitude. The combined Dommel and Aa catchment areas and the Ardennes catchment area are extracted from the data set using the green boxes in Figure 5.3. The precipitation sum over the catchment, thus the sum over the area of the boxes, are used in the analysis, because the highest discharge and precipitation peaks will generally have the largest flood implications in case of simultaneous occurrence. The nine highest discharge peaks at Megen (MU) were analyzed (Figure 5.4). High evaporation rates in summer cause a strong seasonal discharge cycle. The highest precipitation peaks in summer will therefore be stored in the soil or evaporated, and will not result in discharge peaks. As a result, the timing of the nine highest discharge peaks does not match with the nine highest precipitation peaks in the Meuse and Dommel. 


\section{Response times and time lags}

Simultaneous occurrence of discharge waves is caused by a combination of similar precipitation and discharge patterns in two catchments (?). We first analyze the rainfall-discharge response times for the nearest gauging stations upstream of the confluences subject to study, indicated with DD, $\mathrm{AD}$ and $\mathrm{MU}$ in Figure 5.1. For these stations, we calculate the time lags between peaks in rainfall and discharge using the dynamic time warping method (DTW). The time lags are calculated in days and hours for, respectively, the rainfall and discharge.

Subsequently, we analyse the travel time needed for a discharge peak to move from the gauging station to the confluence, based on the celerity of the flood wave (?, p. 64-65). In order to be able to determine the time lag between a main river and a tributary at a confluence, the celerity from the nearest gauging station to the confluence is determined and added to the timing of the measured discharge peaks. The travel time of the discharge peak can be approximated by:

$$
t_{c}=\frac{s}{\sqrt{g \cdot h}}
$$

where $t_{c}$ (s) is the travel time of a discharge peak from gauging station to confluence, $s(\mathrm{~m})$ the distance from gauging station to confluence, $g\left(\mathrm{~m} \mathrm{~s}^{-2}\right)$ the gravitational acceleration and $h(\mathrm{~m})$ the mean water depth during the discharge peak. We used the mean water depth to keep the travel time constant during the discharge wave. The average travel time from the gauging station to the confluence for the Meuse is 2 hours. It is negligible for both the Dommel and the Aa. Hence, in order to calculate the degree of simultaneous occurrence of discharge peaks at the confluence, 2 hours are subtracted from the time lag between the main river and tributary determined from the gauging stations.

Together, these two time lags serve to understand the meteorological and hydraulic conditions leading to the discharge events. In addition, the time lags between the main river and its tributaries were determined, again based on DTW.

\subsection{Results}

Rainfall in the Meuse river basin is mainly concentrated in the Ardennes and surrounding area as a result of orographic effects (Figure 5.5). The 

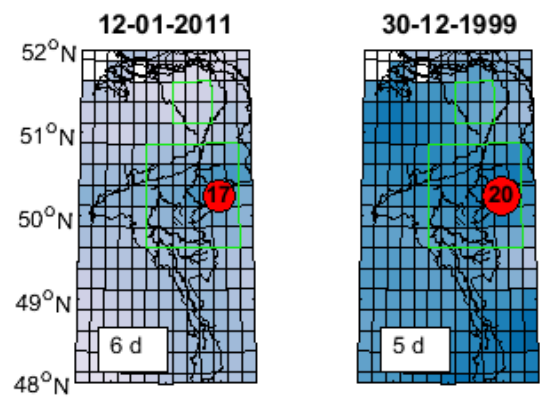

09-01-2012
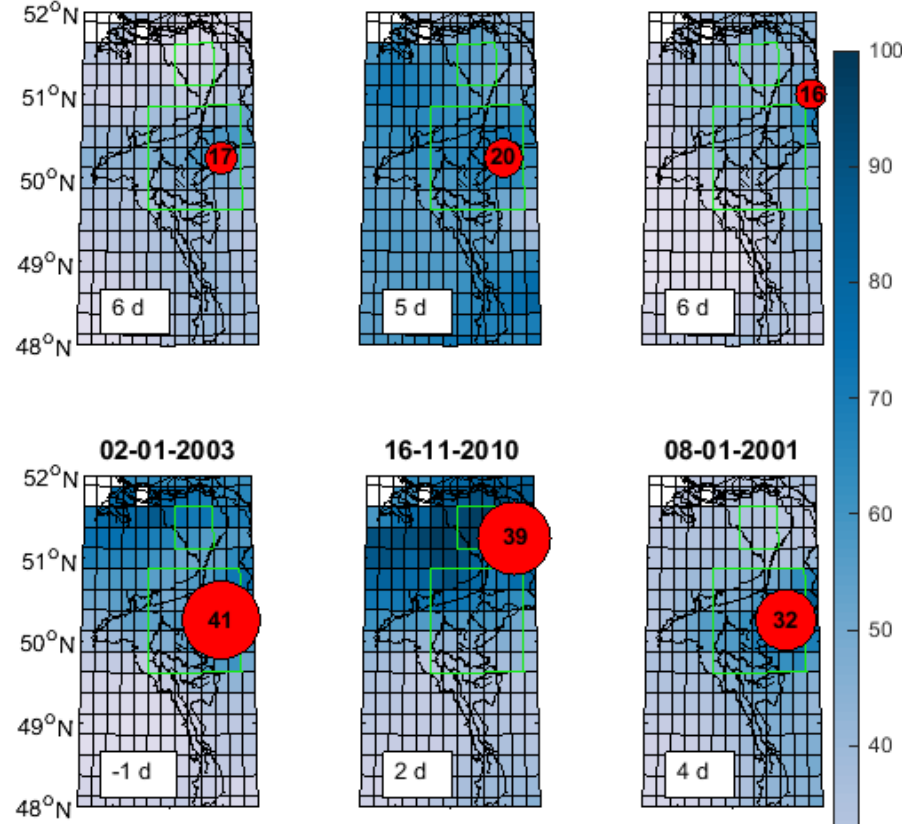

08-01-2001
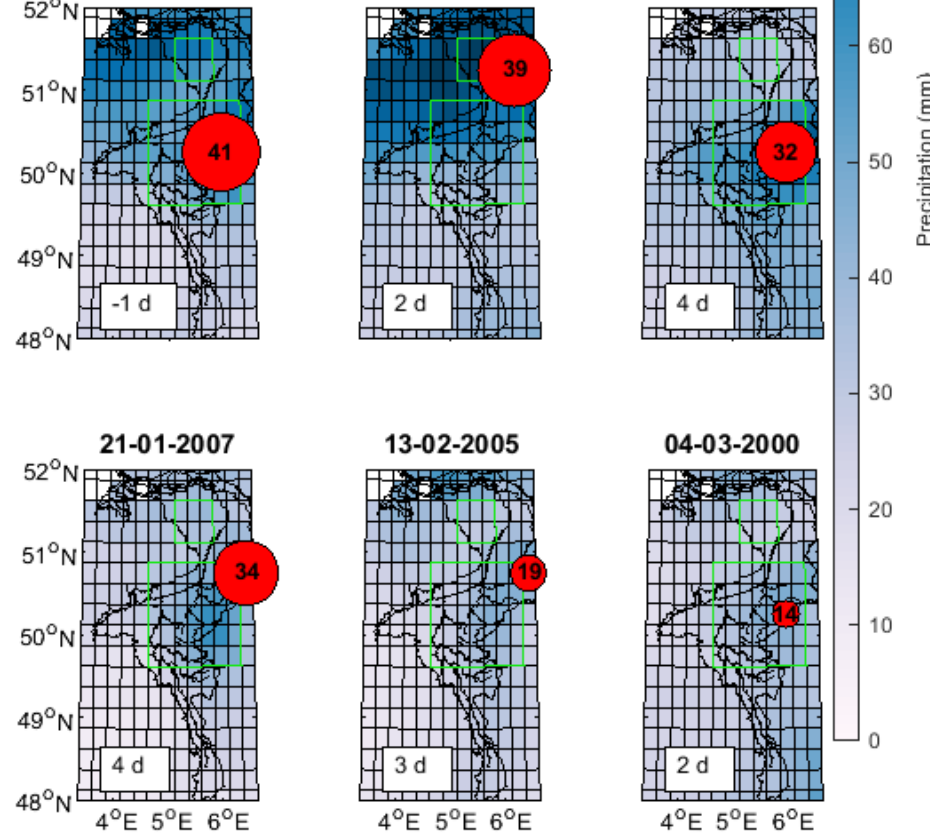

FIGURE 5.5. Distribution of the 5-day precipitation sum preceding the discharge peaks at Megen (MU). The red circle represents the location and the amount of the highest daily precipitation sum $(\mathrm{mm})$. The numbers in the boxes show the time delay between the day with the largest precipitation sum and the discharge peak at MU (d). The flood peaks are arranged from highest flood peak (top left) to lowest flood peak of the nine events (bottom right) 
precipitation patterns of 5-daily precipitation sums preceding discharge peaks show that both catchments typically receive large sums, with the sums over the Ardennes part of the basin generally being larger. Even though the combined Dommel/Aa catchment and the Ardennes catchment are separated by 150 kilometres (the green boxes in Figure 5.5), daily precipitation patterns over the two catchments are spatially correlated (Figure 5.6). Figure 5.6 shows the daily precipitation summed over the Ardennes and the Dommel/Aa catchment areas over the period of the past 45 years. As result of the multiple measurements without precipitation, the data has been transformed into a Gumbel distribution to focus on the high precipitation events. The scatter plot shows that the simultaneous occurrence of the high precipitation events in both the Meuse and the Dommel/Aa catchment areas occur $2.9 \%$ over the past 45 years in relation to $5 \%$ and $0.25 \%$ in case of complete correlation and in case of randomness, respectively. The daily precipitation summed over the Ardennes and the Dommel are not completely correlated due to travel times and increase or decrease of rainfall events. The lines in Figure 5.6 indicate that most precipitation events do not consist of a single day event and therefore a combination of multi-day and heavy precipitation event results in high discharge events. The highest discharge events are caused by multi-day precipitation events or by a series of precipitation events with an interval of a couple of days.

The average response times between precipitation and discharge at the three gauging stations close to the junctions subject to study are 3 days for MU (Figure 5.5), 2 days for $\mathrm{DD}$ and 1 day for $\mathrm{AD}$, with standard deviations of approximately half the average response times. These standard deviations emphasize the large variability of the events. The response times suggest that precipitation events occurring within a two-day interval may lead to a higher probability of simultaneous occurrence of the maxima of discharge waves. Inundations with societal impacts are reported for the discharge events of 2003, 2010 and 2011 in Wallonia (Belgium) and in the southern regions of the Netherlands. The computed response time for the severe precipitation event of 2003 to a discharge peak is negative, because the discharge measuring device failed and consequently leads to an incomplete discharge wave. The high discharge events show that the response time from precipitation to discharge not only depends on the intensity and duration of the precipitation event, but also on wave attenuation (???) and initial conditions of the catchment before the discharge peak, such as antecedent soil moisture (Figure 5.4). 


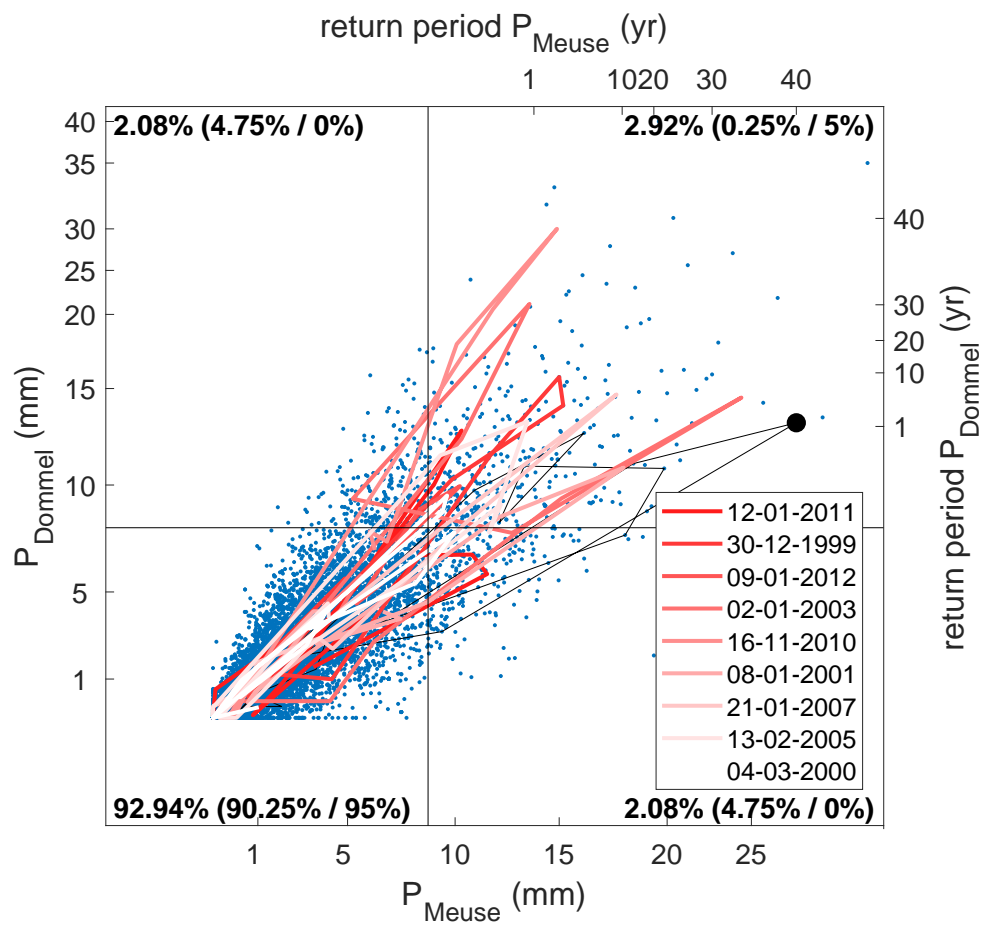

FIGURE 5.6. Gumbel distribution of the precipitation in the combined Dommel and Aa catchments and the Ardennes from 1968 to 2015. The red lines show the precipitation a week prior and a week after the analyzed discharge events in Megen, and the black line shows the precipitation two-weeks prior to the flood event in 1995. The figure is divided in quadrants in such a way that $95 \%$ of precipitation values for the Meuse are located at the left-side of the vertical line and that $95 \%$ of precipitation values at the Dommel are located below the horizontal line. The numbers in the corners successively indicate the percentage of samples in each quadrant and the percentages that would result from complete randomness and exact (1-to-1) correlation. The latter two are in brackets. 
Our results show that the precipitation patterns for the Dommel/Aa and Meuse catchment areas are correlated (Figure 5.6), which underlines the importance of the time lags between the discharge peaks of the Meuse and the Dommel/Aa to assess the potential for simultaneous occurrence of discharge waves. The discharge waves in the Dommel and Aa arrive at the confluence 3.2 and 2.7 days prior to the discharge wave in the Meuse, respectively (Figure 5.7). The time lag of the Aa is thus half a day smaller, likely because of the shorter drainage length and the higher degree of canalization of the channels. The corresponding standard deviations are 16 hours ( 0.67 days) for the Dommel and 28 hours ( 1.17 days) for the Aa. Note that the discharge of the Aa has been measured only since 2004, which explains the absence of time lags prior to 2004. Figure 5.8 shows the average travel time of the nine highest discharge waves along the Meuse catchment. The tributaries increase the peak discharges in the Meuse, which is shown by the increasing circle sizes along the Meuse. In addition, some tributaries show similar time lags at the confluence joining the Meuse, which indicates possible simultaneous occurrence of upstream confluences. We conclude that the average time lags between the arrival of discharge peaks from the Meuse-Dommel and Meuse-Aa confluences are larger than the average response time of discharge at the monitoring stations to precipitation events. Thus, when processes of runoff generation are fast, simultaneous occurrence of discharge peaks is unlikely.

Although discharge peaks may not coincide, the question remains whether the time lag between the discharge waves is large enough to prevent simultaneous occurrence of high discharges. Figure 5.9 shows the precipitation of the Meuse and the tributaries Dommel and Aa, as well as the standardized discharge waves. The colored discharge waves are the periods during which the standardized discharge exceeds the $95^{\text {th }}$ percentile of the time series. Unfortunately, some data gaps (caused by measurement errors) are present in the time series during discharge waves. Despite this, it is evident that all nine highest discharge waves show color overlap and thus coincide.

The fact that simultaneous occurrence of discharge waves takes place for all analyzed extreme events can be explained from the relatively long durations of the discharge waves. The duration of the discharge waves is 9 days on average at MU and even 13 days for the three highest discharge waves (Figure 5.7). The average time lag between the discharge waves of 3 days is therefore too small to prevent simultaneous occurrence. Figure 5.10 shows the discharges in the Meuse and Dommel upstream of the 

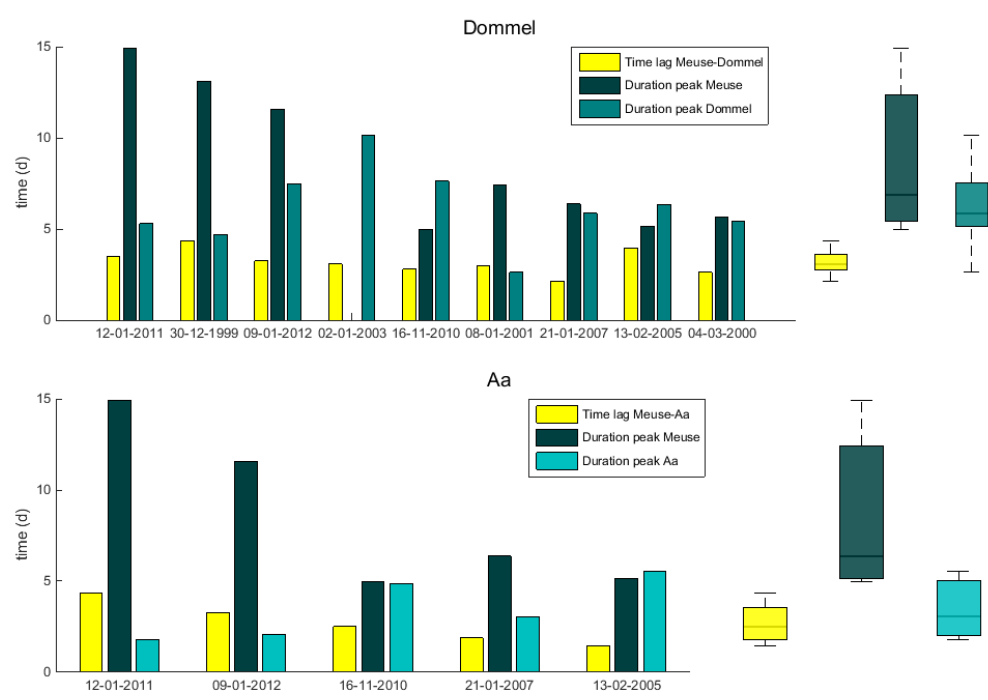

FIGURE 5.7. Duration of the discharge peaks in the Meuse (MU), the Dommel (DD) and the $\mathrm{Aa}(\mathrm{AD})$ rivers and the time lag at the confluence between the Meuse and the Dommel and between the Meuse and the Aa. Box plots show the median, the $25^{\text {th }}$ and the $75^{t h}$ percentiles and the range of the durations and time lags.

confluence over the analysed 15 years, with and without applying a 3-day time shift, corresponding to the left and right panels, respectively. Similar to the precipitation sum, the discharges are transformed into a Gumbel distribution to emphasize the high discharges over the low discharges. The Meuse and Dommel discharge are in $2.5 \%$ of the time both higher than $5 \%$ of their discharge, which is in between complete correlation and randomness. The Meuse and Dommel discharges are not completely correlated as consequence of the time lag between Meuse and Dommel discharge. The application of the time shift increases however the correlation for the highest discharges only slightly, which is apparent from the increase of data points in the top right quadrant from $2.5 \%$ to $2.7 \%$. The lines in Figure 5.10 show that, besides the time shift, most of the nine events move through all quadrants, which implies that the scatter is due to the different peak duration length by for example, spatial rainfall distribution and size of catchment. 


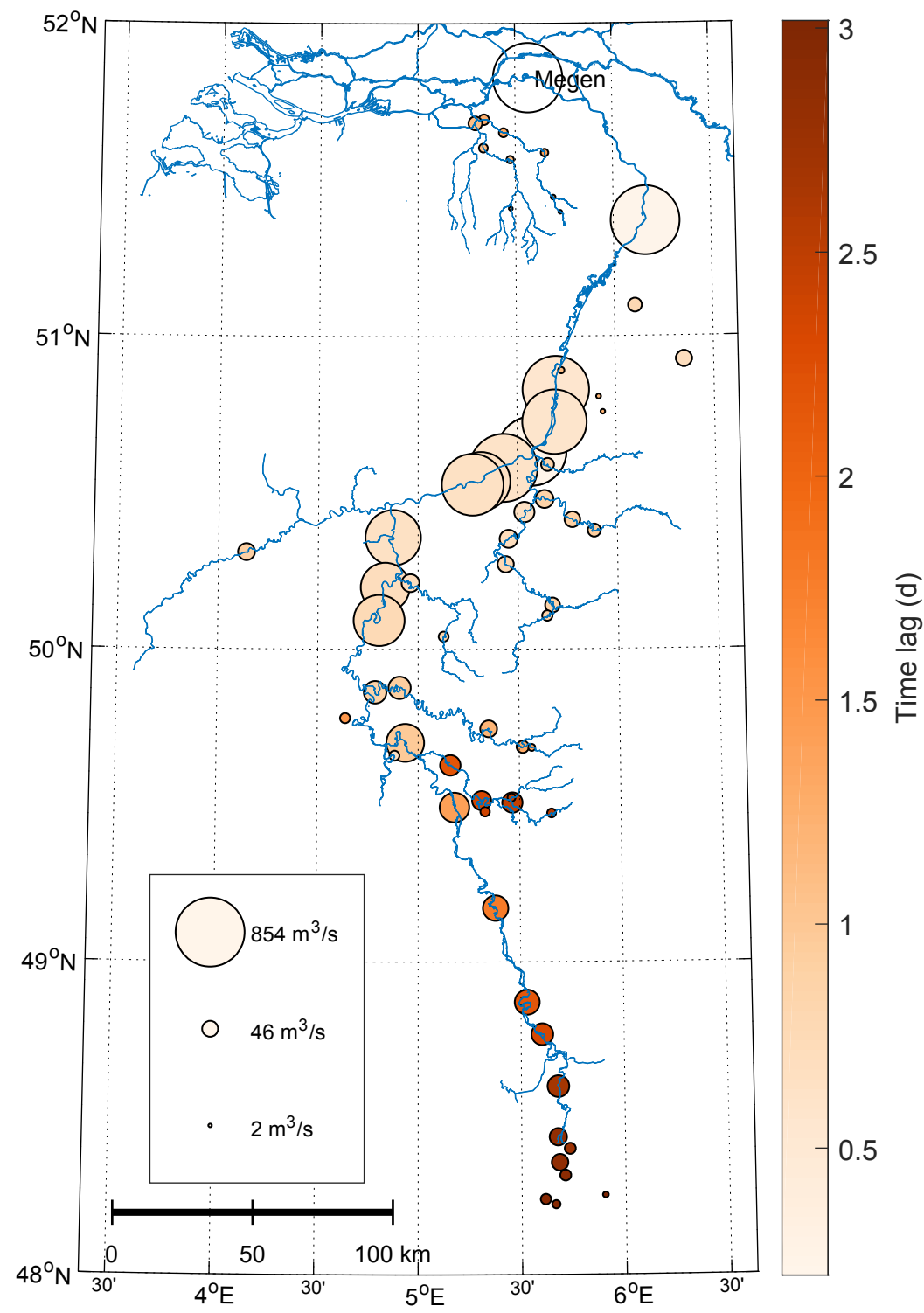

FIGURE 5.8. Distribution of the average travel time of the nine highest discharge waves in the period 1999-2015, between various gauging stations along the Meuse and the confluence subject to study. The circle size indicates the $95^{\text {th }}$ percentile discharge of the gauging station. 

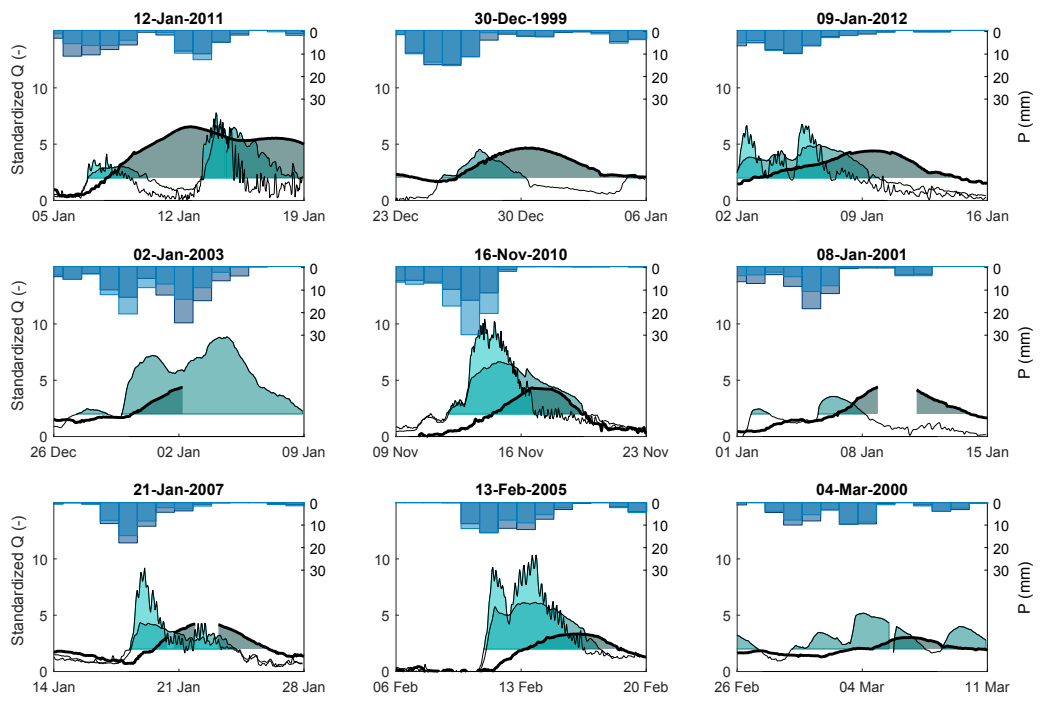

Q Meuse $\square$ Q Dommel $\square$ Q Aa $\square$ P Ardennes $\square$ P Dommel

FIGURE 5.9. Standardized hydrographs of the Meuse, Dommel and Aa rivers for the nine highest discharge peaks (Figure 5.4). The colors indicate discharge exceeding the $95^{t h}$ percentile for the Meuse river (dark green), the Dommel river (lighter green) and the Aa river (light turquoise). The overlap between the colors is indicative of simultaneous occurrence. The precipitation in the catchment areas is indicated by dark blue for the Ardennes catchment and lighter blue for the Dommel/Aa catchment.

From a water management perspective, it is relevant to establish the degree to which simultaneous occurrence of discharge waves affects extreme water levels. During high discharge events the water level difference over a distance of $40 \mathrm{~km}$ in the Meuse between MU and MD (Figure 5.1) increases by about $1.5 \mathrm{~m}$ (Figure 5.11). Afterwards, it decreases to the water level difference typical for normal discharges $(0.5$ to $1 \mathrm{~m})$. The water level differences in the Dommel (between DD and DA) and Aa (between AD and DA), on the other hand, decrease from about $1.5 \mathrm{~m}$ to $0.5 \mathrm{~m}$ and in some cases the difference even vanishes during peak discharges, and increases afterwards over a distance of 4 and $6 \mathrm{~km}$, respectively (Figure 5.11). Hence, the water level differences decrease during a discharge event in the tributaries, reflecting backwater effects of the Meuse on the tributaries also vis- 

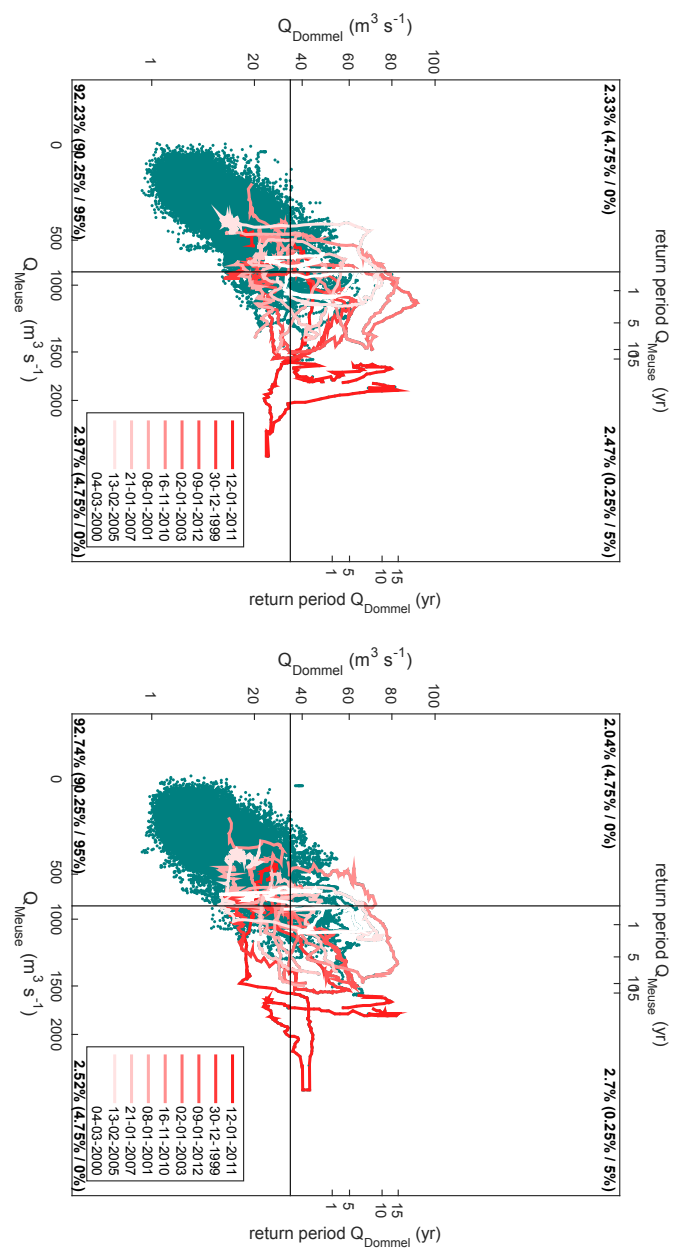

FIGURE 5.10. Gumbel distribution of the discharge of the Dommel and the Meuse from 1996 to 2015. The red lines show the discharge a week prior and a week after the analysed discharge peaks at Megen and follow a clockwise hysteresis. The discharge of the flood event of 1995 was $2.825 \mathrm{~m}^{3} \mathrm{~s}^{-1}$ for the Meuse and $100 \mathrm{~m}^{3} \mathrm{~s}^{-1}$ for the Dommel. The figure is divided in quadrants in a way such that $95 \%$ of discharge values at the Meuse are located at the left-side of the vertical line and that $95 \%$ of discharge values at the Dommel are located below the horizontal line. The numbers in the corners successively indicate the percentage of samples in each quadrant and the percentages that would result from complete randomness and exact (1-to-1) correlation. The latter two are in brackets. 

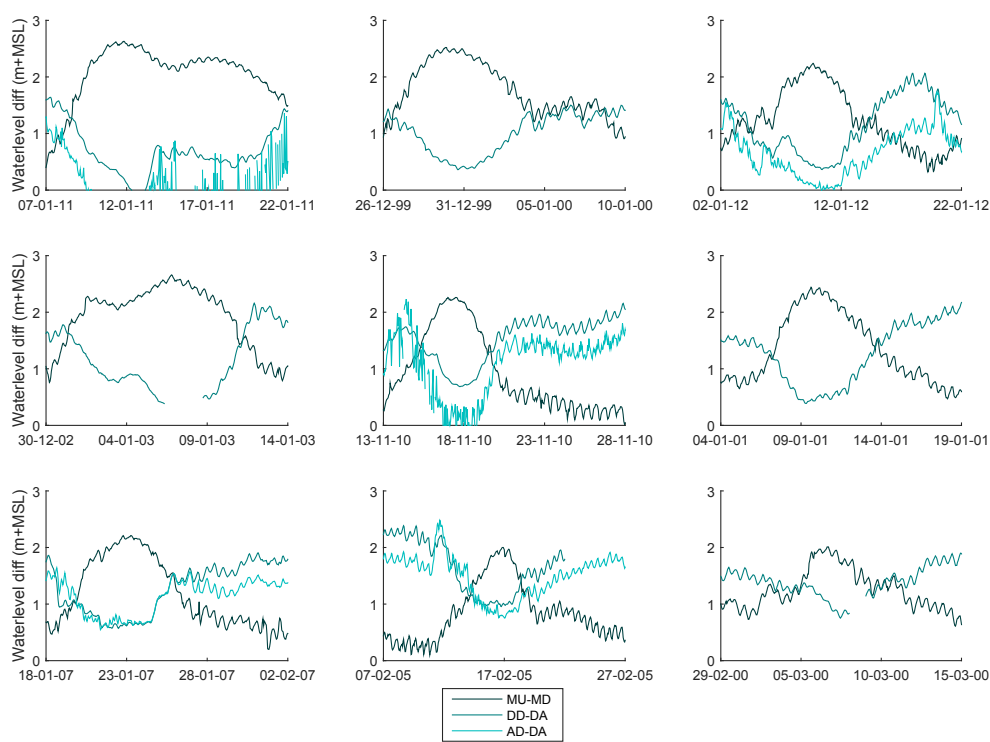

FIGURE 5.11. Water level differences of the Meuse, Dommel and Aa rivers during the nine highest discharge peaks in the Meuse. Note that the water level difference of the Meuse (MU-MD) increases, while the differences of the Dommel (DD-DA) and $\mathrm{Aa}$ (AD-DA) decrease during the discharge peak.

ible in the the corresponding stage-discharge relation (Figure 5.12). The backwater height can reach $1.5 \mathrm{~m}$ over $4 \mathrm{~km}$ from the confluence in the Dommel and Aa tributaries.

\subsection{Discussion}

The exact time lag between discharge waves in the main river and the tributary is shown to be less relevant than the duration and magnitude of the discharge waves. The impacts of simultaneous occurrence of discharge waves depend strongly on the detailed hydrograph of the discharge wave, which may have a composite character. The probability of simultaneous occurrence of discharge peaks, as referred to in existing studies (??), becomes less relevant when the duration of the discharge waves becomes large compared to the time-lag between the arrival of discharge waves from branches joining at a confluence. The amount of discharge before 


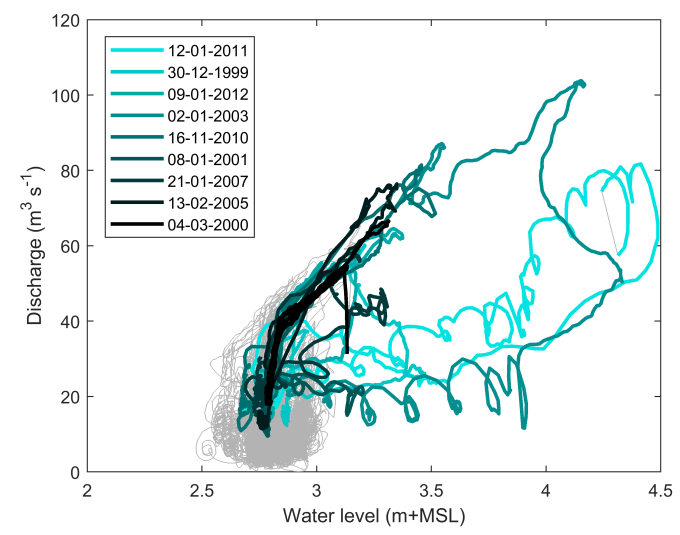

FIGURE 5.12. The stage-discharge relation of the Dommel river at measuring station DD (Figure 5.1). Note that stage and discharge have been measured independently, and that strong non-uniqueness and hysteresis effects can be seen.

or after the peak can be relatively high, and can lead to backwater effects in the tributary similar to those generated during a true event of wave peak coincidence. The choice of an appropriate discharge threshold is critical in the analysis, because it determines the portion of the discharge wave taken into consideration. The threshold here employed to isolate the 9 extreme discharge events does not influence the results of the DTW method, which shows that DTW can be considered a robust tool when analysing the interaction between discharge waves. Catchment properties and climate characteristics are known to determine the duration of discharge peaks (?). This study adds main stream-tributary interaction as an important factor influencing the local duration of a discharge wave in lowland areas.

Based on our analysis and a literature review, the following conceptual framework for simultaneous occurrence emerges (Figure 5.13). The time lag between discharge peaks at the confluence and the duration of the discharge waves are the most important parameters for determining whether discharge peaks coincide (given that precipitation falls over both drainage areas). Figure 5.13 shows the proposed conceptual framework with relations between factors influencing the time to peak discharge at the outlet and the duration of discharge waves. Since the time lag between the catchment is of interest for simultaneous occurrence of discharge peaks, we consider the differences of the factors influencing the time to peak dis- 
charge as conceptual representation of the time lag between the catchments (dashed box in Figure 5.13). The time to peak discharge at the confluence is positively related to the drainage network length, amount of precipitation / discharge and friction and a negatively related to slope and antecedent soil moisture. The slope and drainage length are the predominant factors influencing the time to peak discharge in catchments. The duration of the discharge wave is positively related to the amount of tributaries, friction, duration of precipitation and time to discharge and is thus also related to the factors influencing time to peak discharge. The friction factor can occur in various forms, such as roughness in watercourse, transport through soil or river training by e.g. weirs. Figure 5.13 can be used to conceptual understand the effects of other climates and catchment areas. For example, if most precipitation in the Meuse basin would be concentrated further upstream (which may be expected in many other lowland areas), the difference in travel time would merely increase by about two days (Figure 5.8). Two days extra travel time would still result in simultaneous occurrence of discharge peaks at the confluence for most of the analyzed discharge waves. Another example is the Amazon River for which simultaneous occurrence of discharge peaks is described by?. A discharge wave in the Amazon River lasts for 4 months in the wet season and coincides with discharge waves from tributaries that can peak one month to two months earlier. The simultaneous occurrence of discharge waves in the Amazon region is the result of the duration of precipitation in the Amazon area, which can also last for four months (???). A more extensive investigation into multiple confluences and climates would have an added value in understanding simultaneous occurrence of discharge peaks and the presented method provides a generic tool for further investigation of the influencing factors and processes.

The common practice of determining the discharge using stage- discharge relations is not applicable near confluences, because one cannot account for the backwater effects apparent as hysteresis in a rating curve (Figure 5.12, see also ??). Especially during the highest discharge waves, backwater effects show the most variation. For this reason, the exceedance levels of the upstream stations of the confluence cannot directly be projected to locations closer to the confluence. Establishing the exceedance levels and stage-discharge relations for regions near a confluence therefore presents challenges for water management and introduces one of the causes for spatial variation in flood risk.

The aim of the current Dutch water policy is to retain water in small 


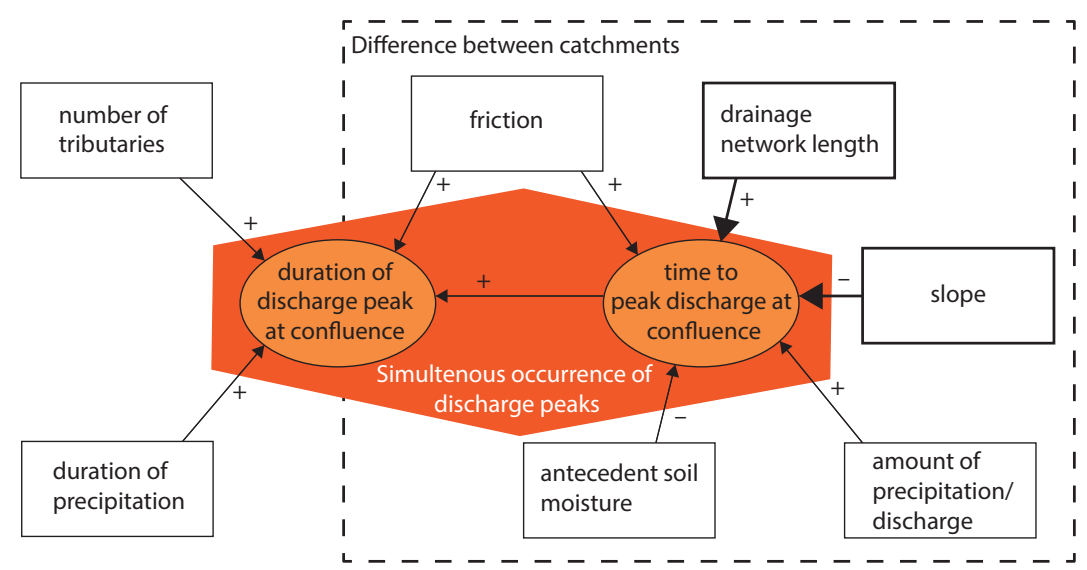

FIGURE 5.13. Conceptual framework of processes controlling simultaneous occurrence of discharge peaks at confluences. When discharge peaks coincide at confluences indicated by the orange polygon, the time to discharge plus the duration of the discharge peaks should overlap. The arrows indicate the factors influencing the time to discharge and/or duration of the discharge peak. The plus signs indicate positive effects and the minus signs indicate negative effects of the factors. The drainage network length and the slope have a larger influence on time to discharge than the other factors. For the time to discharge is it crucial to understand the difference between the catchment areas joining at the confluence, which is indicated by the dashed box.

catchments contributing to the main rivers, mainly to prevent drought and to improve water quality. From a flood risk perspective, water should preferably be retained for the duration of the discharge peak in the main river. An existing concern is that the current practice of water retention in the Dommel and Aa catchments increases flood risk, by enhancing the probability of coinciding flood waves. Our analysis puts the importance of the relative timing of flood waves in perspective. The average duration of extreme discharge events is 9 days in the study area, and it is not so relevant when in this period the peaks in discharge of the Dommel and Aa occur. A significant reduction in flood risk would only be achieved when the water is retained for a period covering multiple rainfall events, which is far from the present-day situation. 


\subsection{Conclusions}

Extreme discharge events at the confluence of the River Meuse and two joining lowland tributaries are studied, introducing a new method of analysis based on dynamic time warping. The method offers robust means of tracing individual discharge waves in discharge time series collected throughout a catchment. The study shows that the precipitation patterns in the catchment areas are spatially correlated. Spatial correlation of the precipitation patterns is a prerequisite for simultaneous occurrence at the confluence. From a comparison of the nine highest discharge waves in the main stream and the joining lowland tributaries it follows that the exact timing of the discharge peaks and the probability of simultaneous occurrence of discharge peaks are little relevant to flood risk. The duration of the discharge wave in the main stream is large compared to the time lags between discharge peaking in the main channel and the tributaries. Initial catchment characteristics produces ambiguous discharge responses to precipitation, such that the timing of duration and magnitude of the discharge peak relative to the precipitation is variable. When discharge waves coincide, the water level difference in the Meuse increases and the water level differences in the tributaries Dommel and Aa decrease. The decrease of water level differences indicates backwater effects in the tributaries due to simultaneous occurrence. The backwater height can increase to $1.5 \mathrm{~m}$ over $4 \mathrm{~km}$ from the confluence in the Dommel and Aa rivers. A public belief is that rapid drainage in a lowland tributary will reduce flood risk, because it diminishes the likelihood of coincident discharge peaks in the main stream and the tributary. In addition, there is a concern that measures of water retention, for example to prevent drought and to improve water quality, will increase flood risk. Our analysis puts this concern into perspective, as a systematic retention in the order of days will only marginally affect peak water levels. 

ChAPter

6

\section{Synthesis}

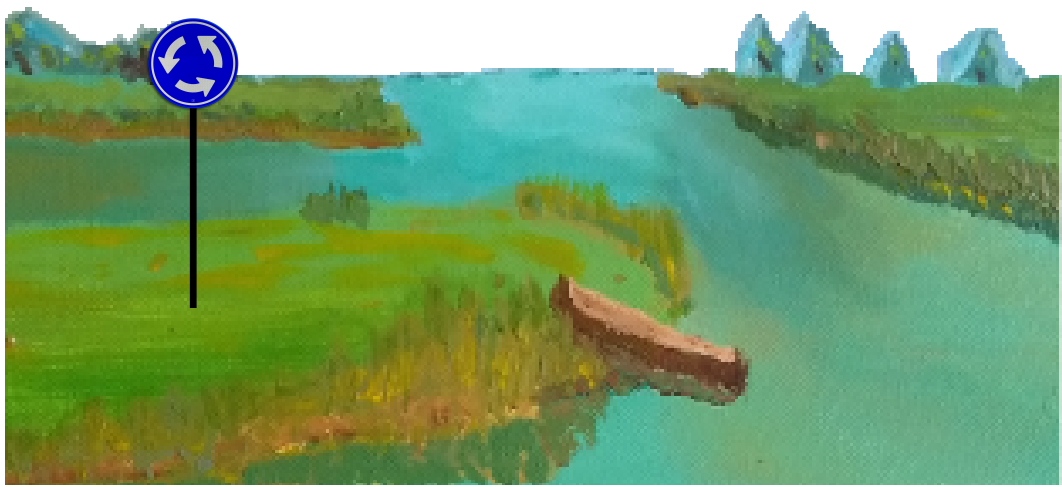




\subsection{Overview of main findings and lessons learned}

This thesis shows the importance of local controls on, and regional impacts of water level and discharge dynamics in lowland rivers. The studies in this thesis vary in their focus on scale, local or regional, and variable, water level or discharge, as illustrated in Figure 1.2 (in the Introduction). Due to their differences, the studies are first discussed one by one, followed by an overview of the findings.

\section{Wood-induced backwater effects in lowland streams}

2.1. What are the observed backwater effects under various flow conditions?

2.2. Can the observed effects be predicted from a conceptual model?

2.3. How sensitive are the predicted backwater effects to the geometry of wood configurations?

Wood in streams increases water levels by means of an enhanced friction and a reduced cross-sectional area. A conceptual model containing both processes is able to correctly simulate the wood-induced backwater effect variation as a result of a changing discharge (answer to 2.1). The wood-induced backwater effect increases with increasing discharge up to a maximum, after which it decreases with increasing discharge (answer to 2.2). This model shows that the width of the inserted wood affects the peak in the backwater elevation, and the height of the inserted wood controls the discharge at which the highest backwater effect is observed (answer to 2.3). Hence, the model can be employed by scientists and practitioners to allow for controlled insertion of wood in streams, without jeopardizing flood protection. By understanding the local water level controls in relation to wood in streams, optimal wood patches can be designed that can retain up to a few cubic meters of water per wood patch.

\section{Flow patterns and backwater effects in sharp lowland river bends}

3.1. How does the appearance of horizontal flow recirculation cells depend on discharge? 


\subsection{Which mechanisms explain the observed changes?}

Horizontal flow recirculation is frequently observed in sharp river bends. Chapter 3 shows that horizontal flow recirculation is not stable with increasing discharge. Measurements were performed in two small rivers: the Essche Stroom and the Dommel Rivers. Measurements in the Essche Stroom reveal a similar flow pattern as described in literature: a longitudinal adverse water level gradient develops because of flow curvature and a cross-sectional area increase. The adverse pressure gradient causes the flow to reverse in both the inner and the outer bend. Measurements in the Dommel bend show flow reversal in the outer bend during low flow. With increasing discharge, the flow reversal vanishes, and then reappears during the highest flow conditions (answer to 3.1). Especially the appearance of the recirculation cell during low discharge is surprising, and cannot easily be explained from the main mechanisms held responsible for flow reversal to date. Moreover, non-stationary flow effects cannot explain the transient character of the recirculation cell. We identify two potential factors: the transverse flow distribution at the entrance of the bend, and three-dimensional effects related to scours holes (answer to 3.2). Additional research is recommended to either reproduce or continuously monitor the state changes in the flow dynamics of the Dommel River.

\section{Regional groundwater response to instantaneous lowering of river water levels}

4.1. What is the characteristic response time of groundwater to instantaneous lowering of river water levels, as function of distance from the stream?

4.2. How does the hydraulic conductivity and specific yield obtained from local pumping tests and estimated using a regional lowering of river water levels differ?

A lowering of river water levels lead to an inflow of regional groundwater and a lowering of groundwater tables result in a loss of groundwater storage. The decreased groundwater storage can be used to retain severe rain events. This process can affect the timing and height of the discharge peaks. By proactively managing the groundwater storage, water levels can be maintained at higher levels during periods without rain. 
When a shipping accident caused a weir failure, the Meuse River water levels were instantaneously lowered, which resulted in an instantaneous groundwater response. Within 3 days, the groundwater levels were lowered by $1.5 \mathrm{~m}$ close to the river to a negligible drop at $2 \mathrm{~km}$ from the river (answer to 4.1). The fast response of groundwater levels in the Meuse area is encouraging for quickly using the soil as additional storage. Additionally, the scaling effect of soil hydraulic parameters was investigated by comparing local pumping tests to regional instantaneous lowering of the Meuse River water levels. The available soil parameters from the pumping tests are preferably applied for understanding the regional groundwater response using the physics-based Boussinesq equations. Chapter 4 shows that the measured saturated hydraulic conductivity from the pumping tests are comparable to the deduced saturated hydraulic conductivity from the river-groundwater exchange. However, the measured specific yield from the pumping tests is not comparable to the specific yield deduced from the regional river-groundwater exchange (answer to 4.2). The currently available data can therefore not easily be used to understand the river-groundwater exchange. In conclusion, the fast response of groundwater levels to an instantaneous river lowering creates a potential to store large amounts of water and thus a potential to increase water levels regionally during periods without severe rain events. Nevertheless, more research is needed on scaling effects and other environmental impacts, such as soil compaction and aquatic ecology before managed lowering of groundwater levels can be used for water retention purposes.

\section{Simultaneous occurrence of flood peaks at a lowland confluence}

5.1. Under which circumstances do discharge peaks coincide at a lowland confluence?

\subsection{How does the coincidence of discharge peaks affect water levels?}

Delaying the timing of the discharge peaks in smaller systems is often seen as a local solution. However, the delaying can have undesired side-effects when discharge peaks regionally coincide, with major consequences for flooding. Chapter 5 shows that the precipitation patterns in the catchment areas are spatially correlated. Spatial correlation of the precipitation patterns is a prerequisite for simultaneous occurrence at the confluence. The nine highest flood peaks from 1999 to 2015 are studied 
at the lowland confluence of the River Meuse with the tributaries Dommel and Aa. Chapter 5 shows that these nine flood peaks coincide due to the long duration of the discharge waves compared to the typical lag times between the flood peaks (answer to 5.1). The discharge waves last on average 9 days, whereas the lag time between discharge peaks is typically 3 days. The exact timing of the flood peaks is thus of little relevance. The simultaneous occurrence of discharge peaks results in backwater effects in the tributaries, which can increase to $1.5 \mathrm{~m}$ over $4 \mathrm{~km}$ from the confluence in the Dommel and Aa rivers (answer to 5.2). Delaying discharge will thus marginally affect the peak water levels despite the substantial backwater effect in the tributaries.

From the different studies, the following general conclusions can be drawn:

- local water level increase can be created by obstruction and/or enhanced friction.

- local discharge delay is not increased by sharp bend processes, however bends contribute to additional advection and diffusion resulting from a longer thalweg.

- regional water level increase can be obtained by preserving higher surface water and groundwater levels during 'normal' conditions and by managing surface water levels before severe rain events.

- regional discharge delay has a marginal negative impact on the simultaneous occurrence of flood peaks at lowland confluences, despite the locally increased water levels in the tributaries.

Water level and discharge dynamics have been the focus of several studies. Water level dynamics are also known to be caused by river width changes as result of obstruction due to natural processes such as vegetation (????), recent sedimentation (??), or due to human-induced interventions such as bridges and spur dikes (????), side channels (??), longitudinal training dams (?) or sediment supply/dredging (??). Moreover, interaction of rivers with tides (?), lakes (?) or other rivers (?, Chapter 5) can cause water level variations. These natural water level variations can result in avulsions (??), chute cut-offs (??) and floodings (??, Chapter 5). Water level changes due to physical changes in the river system can thus have 
a large influence on the environment and should therefore be thoroughly understood.

Discharge is dynamical in space and time because it results from the interaction between net precipitation and catchment characteristics, such as catchment size, river and valley slope, river network and hydraulic roughness. In gauged basins, it is known that flood wave propagation is influenced by changes in hydraulic roughness as result of vegetation or flow in floodplains (???) or as result of river training (???). Moreover, the increasing number of dams strongly influences discharge dynamics (??????). In ungauged basins, research has shown that it is very challenging to understand the natural discharge dynamics (???). To achieve the best water retention measures, it is crucial to understand the water level and discharge dynamics of the system and the influences of the different measures described above.

\subsection{Recommendations for future research}

Several knowledge gaps concerning human-affected water level and discharge dynamics were identified during this thesis project. This thesis concentrates on field work and analyzing field data to focus on the main processes and to be independent of model limitations. However, laboratory experiments would have helped to comprehend the processes in more detail, and model studies could have helped to expand the processes to larger spatial and/or temporal scales. The three described methods thus have their own strengths and weaknesses, but require other methods to advance our understanding of the system. These recommendations, therefore, involve all three methods. The recommendations are first discussed in relation to the chapters, followed by a general overview:

\section{Wood-induced backwater effects in lowland streams}

It was almost impossible to measure the three-dimensional wood geometry (in field experiments). The flow deformation induced by wood was, therefore, simplified in Chapter 2 to focus on the overall impact. Many other studies investigating wood in streams simplified the problem of flow deformation by concentrating on one- or two dimensions and/or partly describe the flow patterns in the stream (e.g. ????). Since cross-sectional permeability is an important factor, these studies risk missing a complete overview of the flow deformation, friction and hence backwater effects. 
Emerging techniques, such as underwater drones, will enable scientists to measure at places which were previously out of reach and to navigate along migrating processes through rivers, such as flood waves, fish and sediments. In relation to wood in streams, underwater drones will be able to measure the three-dimensional wood geometries, the floating of wood and morphological change in time. These processes will increase our understanding about detailed flow deformation and flow resistance resulting in the backwater effects. Using these processes, detailed three-dimensional cross-sectional flow patterns in and around the wood patches can be modelled and potentially measured. This will contribute to our understanding of the impact of permeability and wood-induced backwater effects.

\section{Flow patterns and backwater effects in sharp lowland river bends}

Chapter 3 showed transience of horizontal flow recirculation and identified the downstream flow magnitude and the water surface topography, induced by curvature and cross-sectional increase, as controlling factors for horizontal flow recirculation cells. These controlling factors were analyzed in one-dimensional longitudinal direction, however horizontal flow recirculation is acting in three-dimensions. Additional controlling factors will influence the flow recirculation when it is analyzed in two- or threedimensions . ? concluded that the water surface topography is the principal mechanism for three-dimensional flow velocity redistribution, although inertia and secondary flow are dominant as well. He concluded furthermore that turbulence has a minor influence on flow velocity redistribution. The inflow angle at the bend will determine the experienced flow velocity reduction in the bend, since flow in the outer bank will experience a larger velocity reduction due to the curvature effect (???). Moreover, the bed and bank stability influence the scour hole development and the cross-sectional widening (???), which influences the water surface topography in the bend. The next step is to expand the current analysis of transient flow recirculation cells into two and three dimensions and to elaborate the current analysis with the above-described factors (????). This extended study could be performed in a field situation, a laboratory or a three-dimensional Large Eddy Simulation study (??). For a field study, time lapse cameras can be employed to make short movies at fixed frequencies to understand the timing of transitions of flow patterns and the distribution ratio between the flow patterns. Lasers can be employed to measure the water surface topography in detail. The continuous development of 
new sensors, such as time lapse cameras and lasers (???), will allow researchers to measure different processes simultaneously and to check the consistency between the measurements of different sensors. For a laboratory and a three-dimensional Large Eddy Simulation study, controlling factors can systematically be changed to investigate their interaction with horizontal flow recirculation cells. When these factors are understood in detail, they may possibly be added to one- and two-dimensional models so that the increased understanding of sharp bends can be communicated more easily to people, who are not an expert in this field.

\section{Regional groundwater response to instantaneous lowering of river water levels}

Chapter 4 showed the potential of dynamic groundwater storage by managing river water levels before intense rain events. More research is needed to explore the potential of dynamic groundwater storage in different regional systems. First, the following parameters should be investigated: the timing of river and groundwater lowering, the degree of river lowering in relation to rain events, and the influence on soil characteristics adjacent to the river, such as saturated hydraulic conductivity and antecedent specific storage. This could be investigated in laboratory, experimental field and model studies. In the laboratory study, these factors can be studied using a small constructed river reach in a permeable substrate. In the field study, the groundwater response to the lowering of river water levels can be studied for different catchment states. In the model study, the influence of the above-described factors can be studied in different model dimensions. A multidimensional model will require input data on the multidimensional hyporheic exchange, the detailed aquifer depth topography and/or the detailed heterogeneity of soil parameters (??). However, the input data are often not available and might change with scale. It will likely remain a challenge to find an optimal balance between the accuracy and quality of the input data in relation to the model complexity and the model output (???). This challenge might become larger in the near-future, because model complexity will likely become more dependent on accurate input data than on computational performance due to developments in computer and data sciences, such as increasing computational power, increasing algorithm efficiencies and increasing predictions by artificial intelligence. Secondly, the potential link with operational use of hydrometeorological nowcasting should be studied. Weather prediction models and 
nowcasting schemes are increasing in their spatial and temporal accuracy (???). However, the most intense rain events have small spatio-temporal dimensions (??) and are therefore harder to forecast, while these events have large impacts. The accuracy of nowcasting should be sufficient to manage the lowering of river water levels. Moreover, the dynamic groundwater storage can only become operational if the environmental impacts are well-defined. Possible environmental impacts are responses in the soil as result of the river lowering, such as soil compaction or erosion and deposition at the banks (?). Additionally, river lowering will have ecological effects by giving preference to species that can tolerate temporary high flow velocities and possibly increased sediment load. This should be investigated in more detail. In conclusion, Chapter 4 shows the potential of managing groundwater storage, however managing groundwater system will influence the entire water system.

\section{Simultaneous occurrence of flood peaks at a lowland confluence}

Simultaneous occurrence of flood peaks is likely at lowland confluences and results in backwater effects in the tributaries (Chapter 5). In addition to backwater effects, the flow patterns and morphodynamics in tributaries are also likely to be influenced by the simultaneous occurrence of flood peaks. Typical flow patterns from entrance of the tributary in main river to couple of river widths downstream show: a flow deflection zone, a flow separation zone at the side of the tributary and a maximum flow zone at the opposite side of the tributary, and a flow recovery zone (????). A river bank is often found in the flow separation zone, while a scour hole is often found in the maximum velocity zone. These flow patterns and morphological response are probably affected by simultaneous occurrence of flood peaks. It is, however, unknown how simultaneous occurrence of flood peaks influence these flow patterns and morphological response. ? showed that the sedimentation and erosion pattern in tributaries evolves towards an equilibrium state, however discharge dynamics can temporally impose fluctuations to the morphological equilibrium state. These temporal morphological fluctuations could locally influence the flow and morphological behavior right after simultaneous occurrence of flood peaks. The current knowledge could be expanded by investigating flow patterns and morphological effects during and right after simultaneous occurrence of flood peaks. The current knowledge on simultaneous occurrence could, moreover, be expanded by concentrating on other areas 
with different climates and catchment characteristics (??). Since climate will influence the spatiotemporal scale of the precipitation events resulting in discharge peaks and catchment characteristics, such as valley slope and river network, will influence the celerity of the discharge peak to the confluence. A better understanding of the regional impacts in different areas and the local impacts at the confluence will improve the predictions of simultaneous occurrence of flood peaks.

\section{River's connectivity}

Rivers are, in essence, the landscape features that spatially connect environments in longitudinal (mountains, hills, lowlands and seas), lateral (main channel, bank, floodplain and riparian areas) and vertical direction (hyporheic zone, groundwater, river and atmosphere) (????). They transport water and sediments and provide habitats for animals and plants. Additionally, rivers experience temporal changes, such as flood peaks, droughts, seasonality and global change (e.g. ?). Rivers thus connect space, time and disciplines, such as hydrology, hydraulics, morphology and ecology. This makes rivers inherently complex and dynamic. To decrease complexity and distillate processes, scientists and engineers tend to focus on one discipline and often lose the complete view on the river's connectivity. However, this loss of connectivity leads to loss of habitat diversity, changes in sedimentation and/or changes in water level and discharge dynamics. To counteract and reduce the problems currently faced in surface waters around the world, it is essential to perform multi-disciplinary research and engineering. Since one person cannot be an expert in all the fields and disciplines, interdisciplinary scientific teams would be better in coping with large complex scientific questions, such as river connectivity.

In this thesis, the disciplines hydrology and hydraulics were combined (??). These disciplines might seem similar, but I identify a couple of apparent differences. Hydrology is identified as a science concerned with the earth's water cycle, and hydraulics is identified as a science concerned with the motion of water. Hydrology is mostly performed at catchment scales, while hydraulics is mostly performed at laboratory and (small) river reach scales. Since the spatial and temporal scales are linked in hydrology (e.g. ?), the temporal scales of interest in these scientific disciplines differ as well. When combining the two disciplines, it is crucial to choose similar spatial and/or temporal scales otherwise controlling processes will not match. Methods, however, can be exchanged without spatiotempo- 
ral overlap. Hydraulics could, for example, benefit from the use of more statistics and conceptual modelling as shown in Chapters 2 and 5. Thus, by combining the research disciplines, both methods and concepts from one discipline can lead to new creative insights in another discipline.

\section{Societal impact}

Last but not least, technical aspects are not independent of societal impacts. When water managers, politicians and/or local stakeholders are not involved or convinced, measures are unlikely to be implemented nor maintained (?). All stakeholders should be involved in and convinced of the technical projects, not only those with economic or power interest (??????). ? and ? showed an increased acceptance of large river training projects when stakeholders, including citizens, had the opportunity to express their concerns. ? even showed that local farmers are willing to invest in water measures and are willing to discuss their desires and concerns in stakeholder groups, which provides water managers and politicians to directly react on these desires and concerns. Stakeholders even helped in providing data for scientists (citizen science) (??). Citizen science is an interesting scientific development of increased communication systems and might lead to an further increase of data availability in the future (e.g. ???). Involving stakeholders in group discussions and discuss the desires, concerns and willingness to participate in the projects is an important factor in the eventual success of applying water retention measures. Costbenefit analysis could additionally convince stakeholders, water managers and politicians to act on water retention measures (e.g. ????). A cost analysis for the measures described in the thesis should include the cost of the measure, the societal cost of locally enhanced flood risk in upstream areas and of possible land use changes. The benefit analysis should include the benefits of, for instance, reduced need for irrigation during dry periods as well as the societal benefits of reduced flood proneness of cities along the large rivers. The involvement of stakeholders and the cost-benefit analysis will probably result in new (scientific) questions about the functioning of the water system, which can function as input for new research proposals.

\subsection{Contribution to water management}

An important advice to water managers and politicians is to prioritize the understanding of the impacts of proposed measures and the monitoring of 
their implementations. For the monitoring schemes, it is important to integrate the different disciplines to understand the complete system, which is also described by the river's connectivity. This will ensure that measures are not only a solution in one discipline, but is proving beneficial in other disciplines as well. Moreover, it was apparent that billions of US dollars were spend on stream restoration, but few lessons were learned in the process (?). While monitoring will not only improve our understanding of performed measures in the future, it will also provide a thorough understanding of possible adaptations that contribute to reaching the final objective. It will furthermore improve the setup of measures in other areas. Understanding and monitoring are thus important to ensure current and future cost-efficient and sustainable projects.

As explained in the Introduction, humans have changed the lowland water system in an unsustainable way. The system therefore needs constant maintenance and is causing problems related to fast drainage, such as increased flood levels and prolonged droughts. It is highly inefficient to maintain the system under these conditions and it is harming the habitats of many species. Nature-based solutions (e.g. ??), including river restoration projects, are contributing to tackle this problem. However, the question is whether these interventions can be expanded over large areas so that these nature-based solutions are really retaining substantial amount of water and providing a solution to the problems related to fast drainage. I would advise water managers to perform these nature-based solutions, including making room for the river (???), and to accept that not every farmer and citizen is protected against possible flooding. Since these naturebased solutions might provide local increased flood proneness, they should nationally decrease the flood proneness. These local farmers and citizens should, instead, be better informed on the flooding potential by, for example, pro-active flood early-warning systems and water signs (???). In that way, water managers and politicians do not have to be guided by fear of working in an erratic dynamic system, but managers and politicians have to communicate and explain their responsibilities in relation to the dynamic system. It is therefore crucial to thoroughly understand the water level and discharge dynamics context in which researchers have a task to study and inform. It is thus important that researchers, managers, policy makers and consultants work together and keep learning from our water systems to maintain a livable environment for humans and other biota. 


\section{Bibliography}

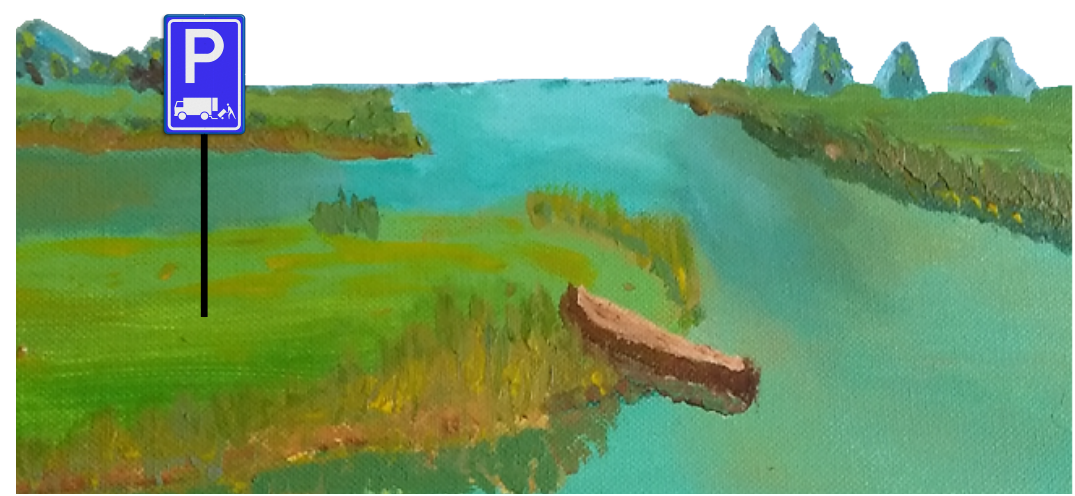





\section{Summary}

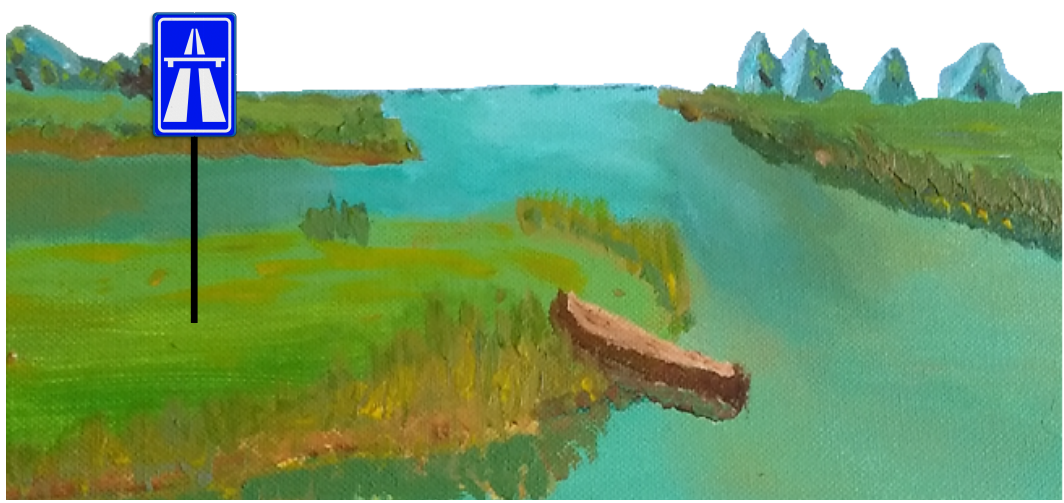


The current water policy aims to accelerate discharge, which is causing problems, such as eutrophication, reduced (aquatic) biodiversity, drastic decline in groundwater levels, increased water levels during floods and prolonged droughts, predominantly in urban areas and densely populated lowland areas. To address and prevent these problems, the water policy should concentrate more on water retention. Few of the existing strategies towards water retention have been evaluated regarding their functionality and quantified impacts on the regional water system. Specifically, regional water systems in lowland areas are defined as areas that freely drain in large rivers and where groundwater is an important component in the water system. In this context, the research focusses on the local and regional effects of increasing water levels and delaying discharge in regional water systems. The current practice of stream restoration involves the construction of meander bends and insertion of wood in streams, asserting local controls on stream conveyance capacity and on water level and discharge dynamics. Backwater effects resulting from sharp bends and the obstruction by wood in streams are currently poorly understood, and are considered key sources of uncertainty in predicting the effects of stream restoration and water retention measures. Regionally, streams are typically analysed in isolation from the downstream river system, with the risk of simultaneous occurrence of discharge peaks in the river and its tributaries. Within a catchment, groundwater variation near rivers is rarely being analysed as a response to surface water dynamics. Progress in understanding the impacts of stream restoration on discharge dynamics requires more knowledge about simultaneous occurrence of discharge peaks in a river and its tributaries, and a deeper understanding of response time dependence on open water-subsurface water exchange. This thesis discusses the topics wood in streams (chapter 2), flow in sharp bends (chapter 3), groundwater reaction as result of instant lowering of river water levels (chapter 4) and the simultaneous occurrence of discharge peaks in a main river and its tributaries (chapter 5).

Wood-induced backwater effects are influenced by discharge, wood configuration and channel geometry. Model simulations and field experiments in chapter 2 show that the backwater effect increases with increasing discharge up to a maximum, after which the backwater effect decreases with discharge. A sensitivity analysis of this model showed that the width of the wood patch is responsible for the peak in the backwater elevation, and the height of the wood is responsible for the discharge at which the 
highest backwater effect is observed. Moreover, the characteristics of this relation depend on wood configuration and channel geometry. These two components may change over time, exerting an impact on the backwater response to discharge condition. Significant morphological adjustments and wood degradation were observed within two to five years after wood placement.

Horizontal recirculation zones are common flow patterns in sharp river bends. Chapter 3 shows that these recirculation zones are not stable with increasing discharge. The Essche Stroom showed similar flow patterns for similar discharge conditions. The Dommel River, on the contrary, showed two distinct flow patterns, one with and one without flow recirculation. With a simple model for bend flow and the one-dimensional depthaveraged momentum equation, it is shown that for the flow pattern without flow recirculation, the flow decelerates according to what may be expected from channel curvature and cross-section variation. For the flow pattern where flow recirculation is present, the model is less easily applicable. Chapter 3 discusses the delicate processes that may or may not result in flow reversal in the Dommel River, highlighting the instability of flow recirculation zones. The water surface topography substantially influences the flow patterns in bends, however, it is too small to be directly measured with standard instrumentation, and is only locally observed in the bends. Two and three dimensional effects, such as lateral redistribution of momentum and the interaction with scour holes, will influence the horizontal flow recirculation. These effects should be incorporated in future analysis to explain the unexpected transience of flow recirculation in the Dommel River.

When the Maas water levels were instantaneously reduced, the groundwater levels responded immediately. Chapter 4 shows that the groundwater levels close to the river were reduced by 1.5 meters within 3 days. The groundwater level reduction was negligible at $2 \mathrm{~km}$ distance from the river. The rapid response of groundwater levels in the Maas area is encouraging to rapidly create additional groundwater storage. Groundwater storage can be created by lowering river water levels, and thereby lowering groundwater levels, before an intense rainfall event. When the groundwater storage is dynamically managed, the timing and height of the discharge peaks can be controlled, and water levels can be maintained at higher levels during periods without intense rainfall. In addition to groundwa- 
ter storage, the scaling effects of hydraulic soil parameters were investigated in chapter 4 , by comparing the hydraulic soil parameters of local pumping tests and of the regional river lowering in the Meuse. The available soil parameters of the pumping test are preferably used to understand the regional groundwater response using the physically-based Boussinesq equations. Chapter 4, however, shows that the measured specific yield from the pumping tests is not comparable with the specific yield obtained from the regional lowering of the Meuse water levels. The currently available data can therefore not be easily used to understand rivergroundwater exchange. It can be concluded that the rapid response of groundwater levels to an instantaneous lowering of the river water levels is promising to store large amounts of water, but scale effects have to be taken into account for application at regional scale.

Extreme discharge events at the confluence of the River Meuse and two joining lowland tributaries are studied, introducing a new analysis method based on dynamic time warping. The method offers robust means of tracing individual discharge waves in discharge time series collected throughout a catchment. Chapter 5 shows that the precipitation patterns in the catchment areas are spatially correlated. Spatial correlation of the precipitation patterns is a prerequisite for simultaneous occurrence at the confluence. From a comparison of the nine highest discharge waves in the main stream and the joining lowland tributaries, it follows that the exact timing of the discharge peaks and the probability of simultaneous occurrence of discharge peaks are of little relevance to flood risk. The duration of the discharge wave in the main stream is larger compared to the time lags between discharge peaks in the main channel and the tributaries. Simultaneous occurrence of discharge peaks result in the backwater effects in the tributaries. The backwater height can increase to $1.5 \mathrm{~m}$ over $4 \mathrm{~km}$ from the confluence in the Dommel and Aa rivers.

Water level and discharge dynamics can change as result of human intervention in lowland river systems. It is important to understand the dynamics in detail before interventions are applied in order to improve, for instance, water retention. A number of interventions have been studied in detail in this thesis. It can be concluded from these studies that:

- local water level increase can be created by obstruction and/or increased friction. 
- local discharge delay cannot be achieved by creating sharp bends, despite the additional advection and diffusion resulting from a longer thalweg.

- regional water level increase can be obtained by preserving higher surface water and groundwater levels during conditions without severe rain events and by managing surface water levels before severe rain events.

- regional discharge delay has a marginal negative impact on the simultaneous occurrence of flood peaks at lowland confluences despite the locally increased water levels in the tributaries.

With the help of these insights, local and regional effects on water level and discharge dynamics can be better understood, and by continuous learning from the water system, a livable environment can be maintained for humans and other biota. 



\section{Samenvatting}

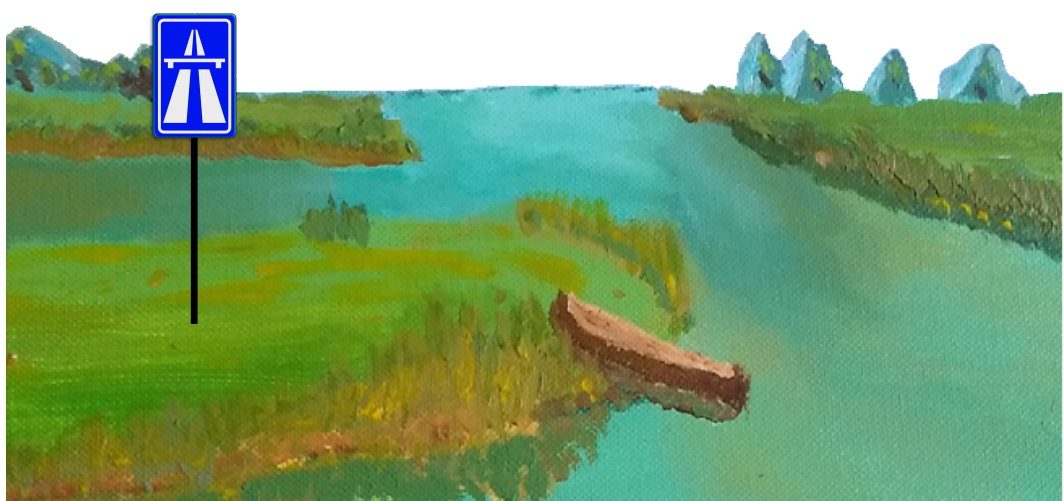


Het huidige waterbeleid heeft als doel water versnelt af te voeren, wat problemen veroorzaakt zoals eutrofiëring, verlaagde (aquatische) biodiversiteit, drastische daling van grondwaterstanden, verhoogde waterstanden tijdens hoge rivierafvoeren en langdurige droogte. Dit speelt voornamelijk in stedelijke gebieden en dichtbevolkte laaglandgebieden. Om deze problemen aan te pakken en te voorkomen, zou het waterbeleid zich meer moeten concentreren op het vasthouden van water. Weinig van de bestaande strategieën voor waterretentie zijn geëvalueerd met betrekking tot hun functionaliteit en effecten op de waterstands- en afvoerdynamiek in het bovenstroomse regionale watersysteem. Bovenstroomse regionale watersysteem in laaglandgebieden zijn gedefinieerd als gebieden die vrij afstromen op grote rivieren en waar grondwater een belangrijk component in het watersysteem is. In dit verband richt het onderzoek zich op de lokale en regionale effecten van verhogen van waterstanden en vertragen van afvoeren in regionale watersystemen. De huidige praktijk van beekherstel omvat de constructie van meanderbochten en het inbrengen van hout in waterlopen, waardoor de lokale transportcapaciteit wordt beperkt en tevens de waterstands- en afvoerdynamiek verandert. Opstuwingseffecten als gevolg van scherpe bochten en obstructie van hout in waterlopen blijven tot op heden slecht begrepen en worden beschouwd als belangrijke bronnen van onzekerheid bij het voorspellen van de effecten van beekherstel- en waterretentie-maatregelen. Regionaal worden bovenstroomse waterlopen doorgaans afzonderlijk van het riviersysteem, waarin ze uitstromen, geanalyseerd. Dit brengt risico's met zich mee van gelijktijdig optreden van afvoerpieken in de rivier en de zijrivieren. Binnen deelstroomgebieden wordt grondwatervariatie nabij waterlopen zelden geanalyseerd als een reactie op oppervlaktewaterdynamiek. Vooruitgang in het begrip van de regionale effecten van waterretentie-maatregelen op de afvoerdynamiek vereist meer kennis over het gelijktijdig optreden van afvoerpieken in een rivier en zijn zijrivieren, en een beter begrip van de responstijd op oppervlakte water- en grondwateruitwisseling. Deze thesis behandelt de onderwerpen hout in waterlopen (hoofdstuk 2), scherpe bochten (hoofdstuk 3), grondwaterreactie naar aanleiding van onmiddellijke verlaging van rivierwaterstanden (hoofdstuk 4) en het gelijktijdig optreden van afvoerpieken in hoofdrivier en zijrivieren (hoofdstuk 5).

De mate van opstuwing door hout in waterlopen wordt beïnvloed door de afvoer, de houtconfiguratie en de geometrie van de waterloop. Modelsimulaties en veldonderzoek in hoofdstuk 2 laten zien dat de opstuwing 
toeneemt met toenemende afvoer tot een maximum, waarna de opstuwing afneemt met toenemende afvoer. Het geïntroduceerde model toont, door middel van een gevoeligheidsstudie van houtconfiguratie, aan dat de breedte van het hout verantwoordelijk is voor de hoogte piek in de opstuwing, en dat de hoogte van het hout verantwoordelijk is voor de afvoer waarbij het hoogste opstuwing wordt waargenomen. Bovendien kunnen de houtconfiguratie en geometrie van de waterloop veranderen in de loop van de tijd, wat invloed heeft op de reactie van de opstuwing op afvoerdynamiek. Significante morfologische aanpassingen van houtdegradatie en/of van oevers werden waargenomen binnen twee tot vijf jaar na plaatsing van het hout.

Horizontale recirculatiezones (neren) zijn gebruikelijke stromingspatronen in scherpe rivierbochten. Hoofdstuk 3 laat zien dat deze neren niet stabiel zijn bij toenemende afvoer. De Essche stroom vertoonde vergelijkbare stromingspatronen voor vergelijkbare afvoeromstandigheden. De Dommel rivier vertoonde daarentegen twee verschillende stromingspatronen, een met en een zonder neren. Met een eenvoudig model voor bochtstroming en een eendimensionale dieptegemiddelde momentumvergelijking wordt aangetoond dat voor het stromingspatroon zonder neren, de stroming wordt vertraagt door de bekende processen van bochtkromming en toename in dwarsdoorsnede. Voor het stromingspatroon, waarbij neren aanwezig zijn, is het model minder gemakkelijk toepasbaar. Hoofdstuk 3 bespreekt de delicate processen die al dan niet kunnen resulteren in het ontstaan van neren in de Dommel rivier, en benadrukt de instabiliteit van neren. De wateroppervlakgradiënt beïnvloedt de stromingspatronen in bochten aanzienlijk, maar het is te klein om direct te meten met standaardinstrumenten en wordt alleen lokaal waargenomen in de bochten. Twee- en driedimensionale effecten, zoals laterale herverdeling van momentum en de interactie met de toename van de dwarsdoorsnede, zullen de neren beïnvloeden. Deze effecten moeten in toekomstige analyses worden opgenomen om de onverwachte vergankelijkheid van neren in de Dommel rivier te verklaren.

Op het moment dat de niveaus van de Maas instantaan werden verlaagd, reageerden de grondwaterstanden onmiddellijk. Binnen 3 dagen werden de grondwaterstanden dichtbij de rivier met $1,5 \mathrm{~m}$ verlaagd. De grondwaterverlaging was verwaarloosbaar op $2 \mathrm{~km}$ afstand van de rivier. De snelle reactie van grondwaterstanden in het Maasgebied is bemoedi- 
gend om snel extra grondwaterberging te creëren. Grondwaterberging kan snel worden gecreëerd door rivierwaterstanden en daardoor grondwaterstanden te verlagen voor een intense neerslaggebeurtenis. Hierdoor kan het moment en de hoogte van de afvoerpieken worden gecontroleerd, en kunnen waterstanden op hogere niveaus worden gehandhaafd tijdens periodes zonder intense neerslag. Naast de grondwaterberging is het schaaleffect van hydraulische bodemparameters onderzocht in hoofdstuk 4 , daarbij zijn de hydraulische bodemparameters van lokale pompproeven en van de regionale daling van de Maas vergeleken. De beschikbare bodemparameters van de pompproef worden bij voorkeur toegepast om de regionale grondwaterreactie te begrijpen met behulp van de fysisch-gebaseerde Boussinesq-vergelijkingen. Hoofdstuk 4 toont echter aan dat de gemeten specifieke berging uit de pompproeven niet vergelijkbaar is met de specifieke berging verkregen uit de regionale daling van de Maas. De huidige beschikbare gegevens kunnen daarom niet gemakkelijk worden gebruikt om de rivier-grondwateruitwisseling te begrijpen. Er kan dus geconcludeerd worden dat de snelle reactie van grondwaterstanden op een onmiddellijke rivierverlaging veelbelovend is om grote hoeveelheden water te bergen, maar voor de toepassing op regionaal niveau moeten schaaleffecten in acht worden genomen.

Een nieuwe analysemethode wordt geïntroduceerd die is gebaseerd op "dynamic time warping" om het samenvallen van afvoergolven bij de confluentie van de Maas en twee zijrivieren te bestuderen. De methode is een robuust middel voor het traceren van individuele afvoergolven in tijdreeksen binnen een stroomgebied. Hoofdstuk 5 toont aan dat de neerslagpatronen in de stroomgebieden ruimtelijk gecorreleerd zijn. Ruimtelijke correlatie van de neerslagpatronen is een voorwaarde voor het samenvallen van afvoergolven. Uit een vergelijking van de negen hoogste afvoergolven in de hoofdrivier en de zijrivieren volgt dat de exacte timing van de afvoerpieken bij de confluentie weinig relevant is voor het overstromingsrisico aangezien de duur van de afvoergolf in de hoofdrivier groter is in vergelijking met de tijdsvertraging tussen de afvoerpieken in de hoofdrivier en de zijrivieren. Wanneer afvoergolven samenvallen, resulteert dit in opstuwingseffecten in de zijrivieren. De opstuwing kan oplopen tot $1,5 \mathrm{~m}$ over $4 \mathrm{~km}$ in de onderzochte zijrivieren.

Waterstands- en afvoerdynamiek kan door menselijk ingrepen worden veranderd in laagland-riviersystemen. Het is belangrijk om de lokale en 
regionale effecten van deze ingrepen in alle detail te begrijpen, voordat de ingrepen kunnen worden toegepast om bijvoorbeeld waterretentie te creëren. In deze thesis zijn een aantal ingrepen gedetailleerd bestudeerd. Hieruit kunnen we concluderen dat:

- lokale waterpeilstijging kan worden gecreëerd door obstructie en/of verhoogde wrijving.

- lokale afvoervertraging neemt niet toe door scherpe bocht processen, echter dragen scherpe bochten wel bij aan afvoervertraging door een grotere longitudinale afstand en daardoor verhoogde advectie en diffusie.

- regionale waterpeilstijging kan worden verkregen door hogere oppervlaktewater- en grondwaterstanden te behouden tijdens droge omstandigheden en door oppervlaktewaterstanden en daarmee grondwaterstanden te beheren voor zware regenbuien.

- regionale afvoervertraging heeft een marginaal negatief effect op het samenvallen van afvoergolven bij laaglandconfluenties, ondanks de lokaal verhoogde waterstanden in de zijrivieren.

Met behulp van deze inzichten kunnen lokale en regionale effecten voor waterstands- en afvoerdynamiek beter worden begrepen en door te blijven leren van het watersysteem kan een leefbare omgeving worden behouden voor mensen en andere biota. 



\section{Dankwoord}

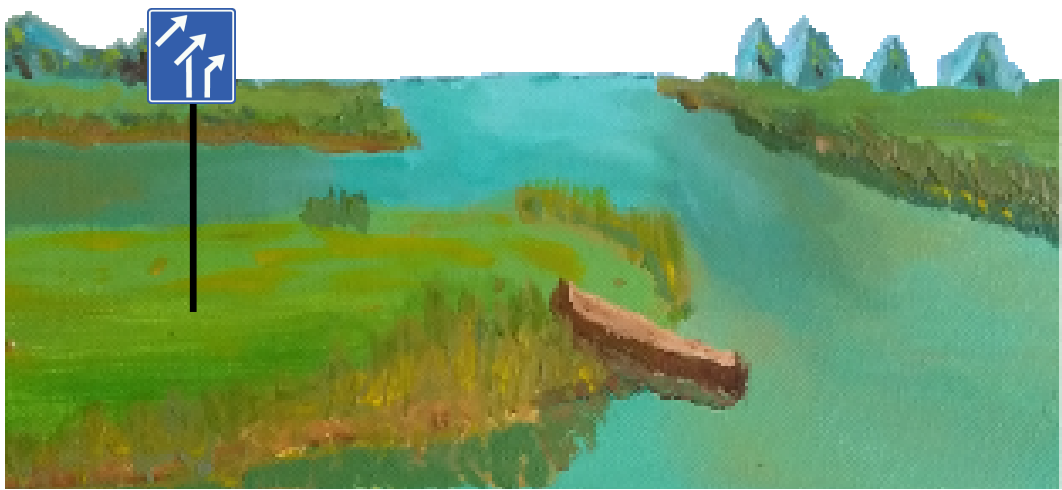


Aan het begin van dit traject heb ik er niet bij stilgestaan dat het schrijven van een boek een eis is voor het succesvolle afronding van het promotietraject . Als ik dát had gerealiseerd, was de moed waarschijnlijk flink in mijn schoenen gezakt. Schrijven is immers een moeilijke taak voor deze dyslect. Toch ben je op dit moment mijn boek(je) aan het lezen. Ik heb dan ook veel geleerd de afgelopen jaren en ben veel mensen erkentelijk voor hun hulp en bijdrage, want zonder deze mensen was het mij niet gelukt. De bijdrage varieert van een intensieve samenwerken tot de welkome afwisselingen van een dansje of een drankje. Ik wil daarom iedereen bedanken die daaraan heeft bijgedragen. Hieronder wil ik een aantal mensen in het bijzonder bedanken.

Als eerste wil ik mijn dagelijkse begeleiders, Ryan en Ton, bedanken. Ryan, hartelijk dank voor je geduld, je enthousiasme en je input. We zijn allebei personen van de 'big picture', dat maakte de samenwerking gemakkelijk. Ik vond het bovendien fijn om samen ideeën te spuien onder het genot van een kopje koffie of thee. Veel succes met de volgende stappen in je carrière, die er zeker gaan komen. Ton, jou wil ik hartelijk bedanken voor je input op schriftelijk niveau, je gedegenheid en je vertrouwen om mij aan te nemen en dit project af te ronden. Ik heb veel van je geleerd. Ondanks dat ons traject wat hobbeliger was, wil ik je bedanken voor je professionaliteit daarin. Veel succes met je toekomstige onderzoeken met o.a. je VICI-beurs. Daarnaast wil ik graag Remko bedanken voor het ondersteunen van mij en de HWM groep. Ik heb altijd veel plezier in en met de groep gehad en er zijn interessante samenwerkingen ontstaan. Je was daarnaast belangrijk aan het einde van het traject van het eerste paper en van het proefschrift. Hier wil ik ook graag Marian, Linda en Sarah en kinderen bedanken voor de tijd die ze aan jullie geven om PhD kandidaten te begeleiden op soms onorthodoxe tijden. Ook wil ik Peter Griffith bedanken voor het persoonlijk schrijftraject. Ik heb veel van je geleerd en echt stappen gemaakt in mijn schrijfvaardigheid. Bovendien heb ik moeten beloven dat ik dit project af zou maken, ondanks alle moeilijkheden die er nog moest komen. Bedankt voor je hulp om mezelf schriftelijk beter te kunnen uiten.

Naast de directe begeleiding wil ik ook graag Paul Torfs, Joris Eekhout en Bart Vermeulen bedanken voor hun tijd en ideeën voor onderzoeksmethoden. Paul, ik heb altijd genoten van je (ongevraagde) adviezen en gezelligheid in de lunches. $\mathrm{Nu}$ je met pensioen bent, is het een stuk rusti- 
ger geworden in de groep. Joris, bedankt voor de introductie in de wetenschap. Ik vind het leuk dat ik (een soort van) je onderzoekslijn in de groep heb kunnen doorzetten op je oude computer en dat we in dit traject ook samen een paper hebben kunnen schrijven. Bart, ik wil jou graag bedanken voor je enthousiasme. Je hebt altijd ideeën voor onderzoeksrichtingen waar ik ontzettend veel van kan leren. Ook Victor Bense, Lieke Melsen en Willem-Jan Zaadnoordijk wil ik bedanken voor jullie betrokkenheid en bijdrage aan hoofdstuk 4. Daarnaast wil ik graag Jasper Candel en Jakob Wallinga bedanken voor hun bijdrage en betrokkenheid bij het project. Jullie bijdrage heeft helaas niet geleid tot een gezamenlijk artikel, maar ik heb goede herinneringen aan onze gezamenlijke reisjes door het hele land en de inhoudelijke discussies. Jasper, ik wil jou graag bedanken voor je energie en de gezamenlijke sparsessies. We hebben in mijn ogen een goede samenwerking gehad en als er meer tijd was, hadden we volgens mij zeker een gezamenlijk artikel kunnen schrijven. Wellicht volgt dit nog in de toekomst. Jakob, ik wil jou bedanken voor de openheid en de motiverende creatieve ideeën.

Verder wil ik de gehele gebruikerscommissie bedanken, vooral Margriet, Leo, Peter-Paul, Christiaan, Michelle, Ellen en Rob waren vaak aanwezig en daarom extra betrokken. In het bijzonder wil ik Rob bedanken, je hebt een grote drive om onderzoek en praktijk te combineren. Soms zo groot dat ik me als onderzoeker in bochten moet wringen om aan je eisen te voldoen. Volgens mij heeft die instelling bijgedragen aan een mooi resultaat. Ellen en Michelle, wil ik ook in het bijzonder bedanken voor de grote betrokkenheid en enthousiasme. Jullie hebben mij geholpen om relevant onderzoek te doen en tegelijkertijd helpen jullie om het onderzoek te promoten onder de waterschappen. Bovendien wil ik Michelle bedanken voor de hulp bij de opzet van het onderzoek in de Essche Stroom en de Dommel en ik wil Frank van Beers, Paul Verkuijlen en de andere handige mannen bedanken die mij hebben geholpen in het veld. Ook Niels Kijm wil ik ontzettend bedanken voor alle hulp tijdens het veldwerk. Je bent een kei in het veld en zonder jouw hulp had ik niet zo'n goede dataset kunnen verzamelen. Vooral voor de Dommel waren je steenwerpvaardigheden cruciaal. Ook wil ik de studenten die mij in het project hebben ondersteund bedanken. Bedankt voor jullie enthousiasme en voor de gelegenheid om mijn persoonlijke begeleidingsvaardigheden te verbeteren; Anouk, Ilja, Stefan, Sander, Bas, Niek en Josco. Graag wil ik ook mijn RiverCare collega's bedanken voor de gezelligheid. Ik denk dat we een goed 
team zijn. Jammer dat we geen tijd hadden om intensiever samen te werken. Frank wil ik speciaal bedanken voor het helpen in het veld om dronebeelden te maken van de houtpakketten. Ook Timo, Jasper, Pepijn, Victor, Liselot, Koen, Menno en Gonzalo wil bedanken voor de gezelligheid tijdens de conferentie en de NCR dagen. Ik kijk uit naar de samenwerking in de toekomst en hoop jullie nog geregeld te zien. Graag zou ik ook Denie, Ralph en Suzan willen bedanken voor het organiseren van vele RiverCare activiteiten en de gezelligheid tijdens conferenties en borrels.

Naast de serieuze samenwerkingen wil ik ook graag de mensen die mij sociaal ondersteunt hebben bedanken. Allereerst wil de IJslanddreamteams 2016, 2017 en 2018, Lotte, Monica, Ryan, Victor, Roel, Lieke en Joost, bedanken voor de weekjes studenten bedienen in het prachtige IJslandse landschap. Gelukkig hebben we de foto's nog. Verder wil ik alle HWM collega's bedanken voor de gezellige lunches, borrels, feestjes of door Lieke georganiseerde $\mathrm{HWM}$ /strategie-dagen. Ik heb goede herinneringen aan de escape room en het laser gamen. Claudia, bedankt voor alle fietstochtjes naar het station. We hebben veel geklessebest over wetenschap, een $\mathrm{PhD}$ doen en alles wat op ons pad kwam. And last but not least, I would like to thank my roomies. Lieke bedankt voor al je hulp. Je hebt mij van begin tot einde geholpen en maakt altijd even tijd voor een babbeltje of om mijn teksten te lezen. Bovendien ben je een goed voorbeeld voor hoe je het in de wetenschap kan maken op je eigen manier met je eigen vaardigheden, ongeacht je leeftijd en geslacht. Je was een mega kracht achter dit proefschrift en daarom ben ik ontzettend blij dat je mijn paranimf bent. Manuel, thanks for having you around in the beginning of this project. You always made me laugh with your 'slijmbal' comments. I miss your smile under your awesome moustache, fist-bump greetings and saying "hasta manana, colegaso(s)". All the best to you and Sara. Karl, we hebben kort bij elkaar op de kamer gezeten bij HWM, maar we hebben lang bij elkaar in huis gezeten in Indonesië. Ik wil je bedanken voor je doorzettingsvermogen zowel in het veld als in discussies. Het heeft mij geïnspireerd om altijd nog een stapje extra te doen tijdens het veldwerk in Nederland. Ich wünsche dir alles Gute für dein neues Übersee-Abenteuer.

Lieve mede-afgangers, Tommy, Femke, Timo en Joost, bedankt voor jullie support en lol in de afgelopen jaren. Ik ben altijd met veel plezier de afgang ingegaan. Tommy, bedankt voor je gezelligheid en je gedegen en standvastige discussies. Succes met je afronding en het programmeren 
van onmogelijke datasets uit verre landen. Femke, bedankt voor alle babbeltjes over dansen, de samenzweringen tegen de mannen en de huppeltjes en onmogelijke yoga-oefeningen in de gang. Sterkte met de gebeurtenissen in je privéleven, die even niet willen meehelpen, maar het komt helemaal goed. Timo, bedankt voor heel veel; de gezellige reisjes naar Padua, Chicago en St. Louis, de discussies over werk en daar buiten en de plezier op de kamer. Ondanks dat ik maar twee paranimfen mag hebben, ben ik blij dat je mijn reserve-paranimf bent. Ik wens je alle goeds met je toekomstige nieuwe baan en nieuwe huis. Lieve Joost, bedankt voor de thee en alle andere dingen. Ik heb het je honderd keer gezegd, maar ik weet niet hoe ik jou moet bedanken. Zonder jou was dit proefschrift niet zo goed geworden als dat het nu is. Je bent mijn sparring-partner geweest in het laatste traject. Je hebt onmogelijke eerste versies gelezen en bovendien hebben we veel lol samen. Je bent van een random collega binnen een half jaar een van mijn beste vrienden geworden. Ik ben blij dat je mijn paranimf bent, want met jou in de buurt kan ik meer dan ik van te voren wist. Ik hoop iedereen die ik hierboven heb genoemd nog te spreken, te zien en leuke dingen mee te ondernemen.

Dan volgt nu de mensen die voor de broodnodige afleiding hebben gezorgd. Lieve, krachtige en stoere Forca-meiden, bedankt voor het jaarlijkse weekendje weg en de gezamenlijke borrels en feestjes. Wat mij betreft mogen we elkaar vaker zien, want als we samen zijn, is het altijd super gezellig. Over een aantal weken krijgt de eerste van ons een kleintje en we hebben ook al de eerste bruiloft in het verschiet. Dat beloofd veel goeds. Stoere Delftse studievrienden, bedankt voor de vele ontspannen momenten tijdens verjaardagen en andere feestjes. Ondanks dat ik uit de crew ben gezet, heb ik altijd veel plezier met jullie. Gelukkig is de vrouwencrew wat uitgebreid de afgelopen jaren, dus genoeg nieuwe vriendinnen erbij om lol mee te trappen. Binnenkort komen Paul en ik weer jullie kant op, om te inspecteren of de Delftsche streken beter zijn dan die rare groene stad met trekkers en hippies. Verder wil ik ook mijn lieve Jueves flamencomaatjes bedanken voor de heerlijke wekelijkse 1,5 uur flamenco dansen en de wijntjes en verhalen achteraf. Ik heb me altijd welkom gevoeld bij jullie. Ook de bata de cola-meiden wil ik bedanken voor de zaterdagse afleiding, want als je ergens je hoofd van leeg maakt, dan is het die rare staart van links naar rechts bewegen. De salsa-maatjes mogen ook niet ontbreken. Bedankt voor de vele dansjes en drankjes die ik met jullie heb mogen doen. In het bijzonder wil ik natuurlijk de Cornet Kings bedanken voor de 
zondaagse gezelligheid bij Stan of Thuis. Helaas gaan we Arnhem verlaten, maar we komen vast nog wel dansjes of drankjes met jullie doen. Ook de Brabantse motormuizen wil ik bedanken voor de gezelligheid. Ondertussen is de club flink uitgebreid met kleintjes, maar dat mag de pret niet drukken. Hans (en Yvonne) bedankt voor de wandelingen en interesse in mij en mijn werk. Coen, bedankt voor je vriendschap en je gezelligheid. We kunnen elkaar een paar jaar niet zien, maar als we elkaar zien, willen we echt weten hoe het met de ander is. Tot snel, allemaal.

Als laatst wil ik ook de families bedanken. Beste Geertsema, Overmeer, Wittmarschen en Landa families, bedankt voor alle feesten, dagen, weekenden en partijen van de afgelopen jaren. Ik ben een echte familiemens en ik hoop daarom dat we nog veel momenten met elkaar kunnen beleven. In het bijzonder wil ik mijn schoonfamilie bedanken. Lieve Ellen, hartelijk bedankt dat we mogen genieten van jouw gezelligheid in Drunen en jouw mooie dansjes bij Scapino Ballet. Je bent een voorbeeld voor veel jonge danseressen en ik hoop nog lang te mogen genieten van je podiumkunsten. Ook buiten het podium mag je me altijd bellen of een afspraak maken. Lieve Tim, ook jou wil ik bedanken voor je gezelligheid. Dat kost je misschien moeite, maar die moeite waardeer ik enorm. Je bent een bijzonder mens en een belangrijke schakel in jouw gezin. Ik hoop nog lang van je te kunnen genieten. Lieve Anneke en Eric, bedankt dat jullie me hebben opgenomen in jullie gezin. We kennen elkaar al een aantal jaar, maar de gezellige zeildagjes en etentjes in restaurants, wennen nooit. Dat we nog maar veel mooie en gezellige dagen mogen beleven.

Lieve Hylkje, mijn grote zus, je bent een geweldig voorbeeld en wellicht de belangrijkste reden dat ik een $\mathrm{PhD}$ ben gaan doen. Het boekje "Master your PhD" en je tips en tricks hebben me enorm geholpen. Zo heb ik het voorbeeld van mijn grote zus toch kunnen volgen en worden we nu allebei doctor. Ook wil ik Matthias en jullie geweldige meisjes, Famke en Merle, bedanken voor alle gezelligheid. Van spelletjes doen tot bierproeverrijtjes met de volwassenen en van boekjes voorlezen tot ravotten met de meisjes. Wat er ook op jullie pad komt, ik sta altijd voor je klaar, want sisterhood (met aanhang) breek je niet zomaar! Lieve papa en mama, bedankt dat jullie altijd achter mij staan, geweldige adviezen geven en me door dik en dun steunen. Mams bedankt voor je eeuwige zorgzaamheid en het luisteren naar mijn sores wanneer ik het nodig heb. Paps bedankt voor al je goede adviezen, je rust en je geduld. Je zinspreuk, “veroordeelen, maar 
verbaas je over de wereld", probeer ik op mijn eigen manier vorm te geven. Ook bedankt dat ik je schilderij heb mogen gebruiken voor de kaft. Jullie zijn een top team samen en ik hou van jullie. Blijf gezond en sterk, zodat we nog heel lang van elkaar kunnen genieten.

Lieve, lieve Paul, in jouw master thesis heb je mij uitgebreid bedankt. Ik hoop dat je ermee kan leven dat ik dat enkel in mijn PhD thesis doe. Ik wil je ontzettend bedanken voor de vrijheid, gezelligheid en steun die je mij geeft. Door die vrijheid kan ik mezelf ontwikkelen en mijn eigen carriérepad uitstippelen, zoals ik dat wil en ik dat nodig heb. Door je gezelligheid hebben we veel lol samen en ga ik graag met je opstap. Zo ontdekken we samen de wereld op onze vakanties en proberen we nieuwe restaurantjes en cafés uit. We sporten en zeilen graag in het weekend om ons hoofd leeg te maken en discussiëren over onze vakgebieden en de wetenschap. Door je steun weet ik dat ik op je kan bouwen. Ik wil je ontzettend bedanken voor de steun en de taken die je op je hebt genomen aan het einde van mijn PhD traject. Met onze drukke carriéres is dat niet altijd makkelijk en je weet dat als jij het nodig hebt ik ook jou zal steunen. Zo komen we er altijd uit en worden we elke dag een hechter team. Binnenkort gaan we weer stappen maken op de burgerlijkheidsladder: we gaan namelijk een huis kopen. Ik ben benieuwd waar die ladder ons brengt. Ik heb zin in de toekomst en heb gezegd.

Tjitske Geertsema Arnhem, november 2019 


\section{SENSE}

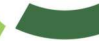

Netherlands Research School for the

Socio-Economic and Natural Sciences of the Environment

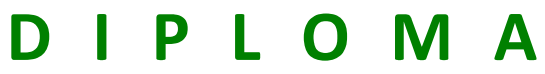

for specialised PhD training

The Netherlands research school for the Socio-Economic and Natural Sciences of the Environment

(SENSE) declares that

\section{Tjitske Janelle Geertsema}

born on 10 July 1989 in Zaanstad, The Netherlands

has successfully fulfilled all requirements of the educational PhD programme of SENSE.

Wageningen, 20 December 2019

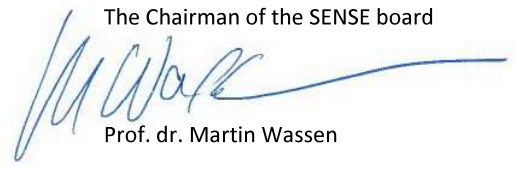

the SENSE Director of Education

The SENSE Research School has been accredited by the Royal Netherlands Academy of Arts and Sciences (KNAW)

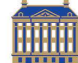

$\begin{array}{llllllllllllllllllllll}K & O & N & I & N & K & L & I & J & K & E & N & E & D & E & R & L & A & N & D & S & E\end{array}$ $\begin{array}{llllllllllllllllllllllll}A & K & A & D & E & M & I & E & V & A & N & W & E & T & E & N & S & C & H & A & P & P & E & N\end{array}$ 


\section{SENSE}

The SENSE Research School declares that Tjitske Janelle Geertsema has successfully fulfilled all requirements of the educational PhD programme of SENSE with a work load of $44.4 \mathrm{EC}$, including the following activities:

\section{SENSE PhD Courses}

- Environmental research in context (2015)

o Research in context activity: 'Initiating and organizing Knowledge Afternoon for Stakeholders and Experts on Hydromorphological Function of Streams (21 februari 2019)'

\section{Other PhD and Advanced MSc Courses}

o River restoration: Fluvial-Geomorphic and Ecological Tools, Institut Beaumont (2015)

- Restoring regulated streams linking theory and practice, Deltares (2015)

- Scientific writing, Wageningen graduate Schools (2016)

- Leadership course, Sta voor, Wageningen (2016)

- Process-based mathematical modelling of bio-morphodynamics, University of Trento, Italy (2017)

- Efficient writing strategies (2018)

o Career orientation (2018)

\section{Management and Didactic Skills Training}

o Supervising two MSc student with thesis and supervising three internships (2015-2018)

- Supervising two BSc students with thesis (2015-2018)

- Assisting practicals of the MSc course 'River Flow and Morphology' (2016-2018)

- Knowledge dissemination days, Rijkswaterstaat, Utrecht (2017)

o Managing user committee meetings (2015-2018)

- Co-organizer of the symposium 50 years celebration of the Hydrology and Quantitative Water Management chair group and the research site Hupsel brook catchment (2015)

- Co-organizer of the Netherlands Centre of River studies (NCR) Conference (2016-2017)

- Chair of the Student Staff Council (2016-2017)

- Secretary of the Student Staff Council (2017-2018)

\section{$\underline{\text { Selection of Oral Presentations }}$}

- Backwater development by woody debris in streams, Netherlands Centre of River studies, 2-3 February 2017, Wageningen, The Netherlands

- Parametric model of wood-induced backwater in lowland streams, IAHR Conference. 1214 June 2018, Trento, Italy

SENSE coordinator PhD education

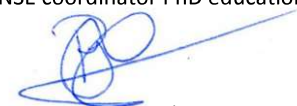

Dr. ir. Peter Vermeulen 
The research described in this thesis was financially supported by the Netherlands Organization for Scientific Research NWO-TTW (grant number P1214). Additional funding was provided by the Dutch Foundation of Applied Water Research, STOWA.

Financial support from Wageningen University for printing this thesis is gratefully acknowledged.

Cover design by Gert Jan and Tjitske Geertsema

Printed by ProefschriftMaken 


\section{Propositions}

1. To create water retention, it is important to understand the entire hydrological system.

(this thesis)

2. Studies in hydrology and hydraulics will benefit from combining and connecting research methods, from conceptual modeling to detailed measurements (this thesis)

3. Maximizing individual research output does not maximize collective scientific advancement.

4. Science should not be seen as objective.

5. To break scientific tradition, early career scientists need to become members of editorial boards and evaluation committees.

6. Universities should maximize scientific creativity rather than scientific production.

7. The capabilities to be humble and to listen are undervalued in the western professional environment.

8. A disability is an asset when the disabled learns to embrace it.

Propositions belonging to the thesis, entitled:

Water level and discharge dynamics in human-affected lowland rivers

Tjitske Janelle Geertsema

Wageningen, 20 December 2019. 